\title{
An overlooked play? Structure, stratigraphy and hydrocarbon prospectivity of the Carboniferous in the East Irish Sea-North Channel basin complex
}

\author{
T. C. PHARAOH ${ }^{1 *}$, C. M. A. GENT ${ }^{1}$, S. D. HANNIS ${ }^{2}$, K. L. KIRK ${ }^{1}$, A. A. MONAGHAN ${ }^{2}$, \\ M. F. QUINN ${ }^{2}$, N. J. P. SMITH ${ }^{1,3}$, C. H. VANE ${ }^{1}$, O. WAKEFIELD ${ }^{1}$ \& C. N. WATERS ${ }^{1}$ \\ ${ }^{1}$ British Geological Survey, Environmental Science Centre, Keyworth, Nottingham, NG12 5GG \\ ${ }^{2}$ British Geological Survey, The Lyell Centre, Research Avenue South, Edinburgh, EH14 4AP \\ ${ }^{3} 2$ Downsview Villas, Camp Road, Freshwater, PO40 9HR \\ *Corresponding author (e-mail: tcp@bgs.ac.uk)
}

\begin{abstract}
Seismic mapping of key Palaeozoic surfaces in the East Irish Sea - North Channel region has been incorporated into a review of hydrocarbon prospectivity. The major Carboniferous basinal and inversion elements are identified, allowing an assessment of the principal kitchens for hydrocarbon generation and possible migration paths. A major Carboniferous tilt-block is identified beneath the central part of the (Permian to Mesozoic) East Irish Sea Basin (EISB), bounded by carbonate platforms to south and north. The importance of the Bowland Shale Formation as the key source rock is reaffirmed, the Pennine Coal Measures having been eroded over wide areas as a result of Variscan inversion and erosion prior to Permian deposition. Peak generation from the Bowland source rock coincided with maximum burial of the system in late Jurassic/early Cretaceous time. A multiphase history of Variscan inversion has generated numerous structural traps whose potential remains essentially unexplored. Leakage of hydrocarbons from these into the overlying Triassic Ormskirk Sandstone reservoirs is likely to have occurred on a number of occasions, but currently unknown is how much resource remains in place below the Base-Permian unconformity. Poor permeability in the Pennsylvanian strata beneath the Triassic fields is a significant risk; the same may not be true in the less deeply buried marginal areas of the EISB, where additional potential plays are present in Mississippian carbonate platforms and latest Pennsylvanian clastic sedimentary rocks. Outside the EISB, the North Channel, Solway and Peel basins also contain Devonian and/or Carboniferous rocks. There have however been no discoveries, largely a consequence of the absence of a high quality source rock and a regional seal comparable to the Mercia Mudstone Group and Permian evaporites of the Cumbrian Coast Group in the EISB.
\end{abstract}

The productive oil and gas fields of the EISB evidence a working, Carboniferous-sourced petroleum system. Whilst a great deal may be known of the Triassic reservoir and seal (Meadows et al. 1997), little is known about Carboniferous and Permian petroleum systems at depth and in adjacent basins, that may offer significant additional potential. Following the Wood Review (2014), Palaeozoic plays, including that of the greater Irish Sea area were identified as priority for building regional digital datasets and stimulating exploration. In response, the $21^{\text {st }}$ Century Exploration Roadmap: Palaeozoic Project running from 2014-2016 and openly released in 2017, undertook regional scale seismic and well interpretation, source and reservoir screening studies and basin modelling. This paper provides a re-interpretation of the structural history of the greater Irish Sea, and its influence on potential Carboniferous and Permian prospectivity including the marginal basins.

The Carboniferous structure and stratigraphy of the UK sector of the East Irish Sea-North Channel region has been reviewed using all available well and seismic reflection data. The project interpreted about 40,000 km of 2D seismic data of many vintages from 1980-2000, with local infill from 
3D data, to generate time and depth-converted surfaces for key Palaeozoic surfaces (Pharaoh et al. 2016a). Priority was given to the interpretation of long regional speculative lines, with infill from licenceand prospect-scale surveys. These surfaces were then used as the basis for an assessment of Palaeozoic hydrocarbon prospectivity (Pharaoh et al. 2016b), which forms the core of this paper. For brevity, the seismic interpretations are summarised using synoptic diagrams ('cartoons'). The present economic focus of the hydrocarbon province is the Morecambe Bay gasfield and its satellites, located within the EISB, a basin complex of Permian to Mesozoic age comprising a number of mainly N-S oriented graben and intervening platforms (BGS 1994; Jackson et al. 1987, 1995, 1997). The principal structures of the EISB are strongly discordant to those in the pre-Permian substrate however, which bear the imprint of a long and complex evolution culminating in the Variscan Orogeny in latest Carboniferous time. For these Devonian and Carboniferous tectonic elements, a new terminology is presented here and the lithostratigraphical nomenclature of Waters et al. (2011) is used to integrate onshore and offshore successions, allowing more precise correlation than the scheme introduced by Jackson et al. (1997)..

The Bowland Shale Formation is recognised as a prolific source of gas for the Permo-Triassic reservoirs (Armstrong et al. 1997), but potential Namurian and Westphalian reservoirs suffer from low porosity and permeability due to the combined effects of Variscan inversion, deep burial in a PermianMesozoic rift, Cenozoic inversion, magmatism and thermal effects associated with the rifting of the North Atlantic (Meadows et al. 1997; Quirk \& Kimbell 1997). Several areas on the margins of the EISB (ManxFurness Ridge, Cumbrian margin, Fylde margin, Cambrian margin) are underlain by the offshore extensions of onshore coalfields or Namurian strata. These areas are covered in some detail by seismic data, and the availability of onshore analogues allows a more realistic assessment in terms of potential for development of non-conventional resources, perhaps from coastal locations.

\section{Methodology and datasets}

The exploration datasets used in the regional interpretation are depicted in Fig. 1. The 2D seismic datasets include regional speculative data supplied by geophysical companies (CGG, IHS and WesternGeco); licence- and prospect-level datasets provided by the Common Data Access Initiative (CDA) offshore and United Kingdom Onshore Geophysical Library (UKOGL) nearshore and onshore; and data supplied directly by participating companies (Centrica plc). The 3D dataset used was supplied by CDA, augmented by data from the 3D Terracube supplied by CGG. The well picks were supplied from the DECC well database at BGS Edinburgh, with further interpretation during the project. Wells used in the petrophysical analysis are highlighted with a circle.

\section{Pre-Carboniferous structural evolution}

The crust of the southern part of the region (North Wales, Anglesey and adjacent offshore areas (Fig. 2) was generated as volcanic and sedimentary complexes in magmatic arc-trench systems during late Proterozoic time. Many early tectonic lineaments (e.g. the Menai Strait Fault Zone; Gibbons 1987) are associated with the accretion and dispersal of various terranes along the margins of Gondwana in Neoproterozoic to Cambrian time. Many of the lineaments (Dinorwic, Berw) have a SW-NE trend, are relatively straight (implying steep upper crustal geometry) and have been serially reactivated in Acadian sinistral transpression, Devono-Carboniferous extension etc. The crust of the northern part of the area (Midland Valley, Scottish Highlands) was generated throughout Proterozoic time. A Neoproterozoic supracrustal metasedimentary sequence, the Dalradian Supergroup, was strongly deformed during the Grampian phase of the Caledonian Orogeny (Smith et al. 1999; Chew \& Strachan 2014). Its southern limit is marked by the Highland Boundary Fault, which forms the northern boundary of the area of investigation.

The crust in the central part of the region comprises early Palaeozoic sedimentary complexes belonging to several different terranes forming part of the Avalonian (Monian, Lakesman) and Laurentian 
(Southern Uplands, Midland Valley) margins of the Iapetus Ocean, and accreted during the Caledonian Orogeny (Bluck 2002; Barnes et al. 2006; Chew \& Strachan 2014). Numerous major tectonic lineaments have a typical SW-NE 'Caledonide' trend. These include the Carmel Head Thrust of northern Anglesey, and reactivations of the earlier Monian lineaments; the Causey Pike Thrust and Southern Borrowdale Lineament of the Lake District (Barnes et al. 2006); the numerous accretionary tracts of the Southern Uplands massif (Bluck 2002); and numerous faults with this trend within the Southern Highlands terrane (Chew \& Strachan 2014).

In this study, a NW-dipping zone of enhanced reflectivity in pre-Carboniferous 'basement', previously referred to as the Barrule Thrust (Chadwick et al. 2001), was mapped over a large area to NW of the Isle of Man. The analysis of the deep seismic reflection data presented by England \& Soper (1997) suggests that this structure lies within the Avalonian footwall of the Iapetus Suture, rather than representing the suture itself. A further zone of NNW-dipping basement reflectivity underlies the southern part of the EISB (Jackson \& Mulholland 1993; Pharaoh et al. 2016a' 2016b), being particularly prominent beneath the Conwy Platform, just off the north coast of Wales (Fig. 2). The dip of this zone steepens as it approaches the coast, and it is inferred to correlate with the southernmost strands of the Menai Strait Lineament, i.e. the Menai and Dinorwic fault zones. Although the seismic coverage is relatively poor in this area, the available data suggest that this zone represents the deepest regional detachment, with all subsequent extensional faulting (of Carboniferous and Permian-Mesozoic age) penetrating no deeper into the crust.

During the Acadian phase of the Caledonian Orogeny, most of the lineaments identified above were reactivated within a sinistrally transpressive regime, associated with the late orogenic collapse of the Caledonian mountains chain, stretching from the Appalachians through Ireland and Scotland to Greenland and Norway (Chew \& Strachan 2014). The most obvious element of this regime is the Great Glen-Walls Boundary Fault system. Devonian strata are thickest in the north of the study area, in the Midland Valley and form the molasse to the Caledonian Orogen (Trewin \& Thirlwall 2002). In the south (Anglesey), Devonian strata are more limited in development and related to local faulted basin margins (Hillier \& Williams 2006). In this tectonic regime, W-E extension is anticipated (Coward 1993). Basins related to such an orientation are tentatively identified within the Orcadian Basin (Leslie et al. 2015) but are less clearly identified in the study area, except perhaps, in the rift basins (North Channel, Stranraer, Carlingford Lough) within the Southern Uplands Massif, and the Peel Sandstone Graben of the Isle of Man (Maddox et al. 1997; Parnell 1997; Quirk \& Kimbell 1997).

\section{Carboniferous structural and stratigraphic evolution}

An extensional- transtensional tectonic regime persisted into Carboniferous time (Leslie et al. 2016). Although a general W-E extensional regime has been invoked in Mississippian time (Coward 1993), extension occurred on faults with a diversity of orientations, but with reactivation of earlier basement structures (of various trends) being a common feature, e.g. in the Northumberland Basin (De Paola et al. 2005). This reflects partitioning of the tectonic regime (Leslie et al. 2015). East of the study area, in Lancashire, the Bowland Basin reflects deeper water deposition in a basin bounded by SW-NE trending faults (Pendle Monocline etc) representing reactivations of earlier basement structures (Kirby et al. 2000). The Solway Basin is the offshore continuation of the Northumberland Basin (Chadwick et al. 1995), and is controlled by major bounding faults on a SW-NE trend. The Peel Basin along strike to the SW, has a similar trend but opposite structural polarity and a very different basin setting in the Carboniferous (Fig. 2). However the evolution of both basins appears to have been strongly influenced by the extensional reactivation of underlying structures in the Caledonide basement. The Midland Valley (and Firth of Clyde basins) also exhibit a SW-NE trend, which persists up to the Highland Boundary Fault.

\section{Carboniferous extensional basins}

The Carboniferous substrate of the EISB comprises a number of basin elements, comparable to that of the UK onshore. Fig. 2 presents a speculative reconstruction of the principal tectonic elements in 
Mississippian time. It is based heavily on seismostratigraphic and structural interpretation, as only five offshore boreholes penetrate Visean strata in the whole of the province (112/25a-1 and 113/27-2 in the EISB; 111/25-1A and 111/29-1 in the Peel Basin; and 112/19-1 in the Solway Basin, Fig. 2). In the centre of the EISB, a major basin, here referred to as the Eubonia Tilt-Block (Fig. 2), is inferred to extend from the Quadrant 109 (Q109) Syncline in the SW (BGS 1994) to the Ogham Platform (Fig. 2). Extension farther east, beneath the Lagman and Tynwald (Permian-Mesozoic) basin of the EISB, towards the western edge of the Lake District, is also inferred. The presence of a major half-graben (tilt-block), controlled by a major syndepositional bounding fault on its NW margin, the Eubonia-Lagman Fault System (Fig. 2, 3a), is indicated by the seismic reflection data. The structure was not identified as a tiltblock by Jackson \& Mulholland (1993; p800), but they did recognise the marked asymmetry of the northern limb of the Q109 Syncline/Basin and the presence of up to $7.5 \mathrm{~km}$ of Visean to late Westphalian (and possibly Stephanian) strata. Fig. 3a shows a seismic line extending SE with up to $7.5 \mathrm{~km}$ of Visean to late Westphalian (and possibly Stephanian) strata from the Isle of Man towards Anglesey (Fig. 2). It demonstrates the presence of over $2.5 \mathrm{~s}$ Two-Way Travel Time (TWTT) of Carboniferous strata east of the Eubonia Fault, in what is referred to as the Eubonia Tilt-block (Pharaoh et al. 2016b). Poor well control is provided by a few distant wells on the western edge of the EISB (Fig. 2) and the picks are not well constrained

Towards the top of the tilt-block in the south, on the Holy Island Shelf, brighter reflectivity in the upper Visean interval, may represent the development of reefal carbonates. The southern end of the section crosses a northward-vergent inversion anticline-thrust couple, defining the northern limit of the Môn-Deemster Fold Belt. This is a 25 km wide belt of strong Variscan inversion, extending ENE from the north coast of Anglesey, from the Q109 Arch to the Deemster Platform (Fig. 2). The internal structure of this belt is imaged on numerous N-S profiles crossing the Godred Croven Basin, and Fig. 3b, an arbitrary line through 3D data in this area, is representative. A schematic profile is presented in Fig. 4b. A series of parallel WSW-ENE trending anticlinal folds has been mapped through the area. The internal structure of this inversion belt is complex, comprising a fan-like array of anticlines and synclines with associated thrusts, SSE-vergent in the south, and NNW-vergent in the north (Fig. 4b). Fig. 3b clearly shows discordant reflections in the Visean sequence, extending down into the Caledonian basement, interpreted here as fault-plane reflections. Below 3s TWTT, a further zone of intra-basement reflectivity is interpreted as a deeper Caledonian detachment surface, as recognised by Jackson \& Mullholland (1993; p805). Well 110/07b- 6 was clearly a test of the structure with the greatest amplitude, at the northern end of the profile. This slightly deviated well proved $450 \mathrm{~m}$ of (presumed) Namurian Bowland Shale Formation (unbottomed) beneath $550 \mathrm{~m}$ of Millstone Grit Group, Westphalian strata being absent beneath the Base-Permian unconformity (Fig. 3b). As noted above, northward-vergent structures have been identified on the northern edge of the Q109 Arch (Fig. 3a), and they have also been mapped beneath the northern part of the Deemster Platform. Several NNW-SSE to N-S trending graben of the EISB (Godred Croven, Gogarth and East Deemster basins) discordantly overlie this Carboniferous hinge-zone. The inversion belt is very similar in its structure and orientation to the Ribblesdale Fold Belt of the Lancashire onshore, representing the Variscan-inverted Bowland Basin (Corfield et al. 1996; Kirby et al. 2000). It seems logical to infer connection of the two, via the Fylde coast of Lancashire, as proposed by Corfield et al. (1996). If this inference is true, then the southern edge of the zone may represent a reactivated extensional fault, analogous to the Pendle Lineament of Lancashire; and the Visean carbonate platform (Holy Island and Conwy platforms) to the south, with a thin or absent Namurian cover, are the equivalent of the Central Lancashire High (Kirby et al. 2000).

That part of the Eubonia Tilt-block lying east of the Keys Fault was subsequently almost obliterated by the combined effects of latest Variscan inversion and pre-Permian erosion. The original eastern limit of the tilt-block is uncertain. It likely continued beyond the Tynwald Basin, where the enechelon faults of the Lake District Boundary Fault System may have acted as transfer faults, offsetting extensional subsidence farther south into the Craven Basin. On the northern margin of the tilt-block, to NW of the Eubonia-Lagman Fault System, an extensive shallow marine carbonate platform developed in 
Visean time. This is well represented by outcrop in the south of the Isle of Man (Chadwick et al. 2001), the northern edge of the Lake District and adjacent offshore (Ramsey-Whitehaven Ridge) (Fig. 2). Because of significant pre-Permian uplift and erosion, it is not possible to determine the subsidence regime in which Westphalian strata were deposited, but it was probably dominated by post-extensional thermal subsidence, as elsewhere in southern Britain, the depocentre lying near Manchester (Fraser et al. 1990; Fraser \& Gawthorpe et al. 1990).

A few wells penetrate the Carboniferous sequence beneath the Peel Basin (Fig. 2) and demonstrate that an extensive carbonate platform (Manx Platform and Strangford Shelf) extends west to Ireland and north towards the North Channel. The present study revealed that the undifferentiated Carboniferous strata on BGS (1994) mapping are principally of Visean age, Namurian strata being largely eroded (Pharaoh et al. 2016a). The Permo-Triassic Peel Basin has the form of an asymmetrical graben controlled by a major bounding fault on the northern side (Fig. 4c), and extensional faults with smaller throws on the southern side, developed in the hangingwall of the Barrule Thrust (Chadwick et al. 2001). Lack of evidence for significant Carboniferous syndepositional throw, and the larger Permo-Triassic throws, suggests that there was probably not a significant basin here in Visean time, although the poor quality of the seismic data allows some uncertainty. Faulting at the top of the Appleby Group (Permian) has a predominantly NW-SE trend (Quirk et al. 1999), akin to that of the North Channel Basin.

In contrast, the Solway Basin, underlying the Permian-Mesozoic Carlisle Basin along strike to NE of the Peel Basin, is asymmetrical with a principal controlling fault on the southern side (RamseyWhitehaven Ridge) (Fig. 5a). The Carboniferous basin fill comprises fluviodeltaic Border and Yoredale Group strata with greater affinity to the Northumberland Trough sedimentary sequence than the carbonate platforms of the southern Irish Sea (Chadwick et al. 1995), together with a greater thickness of preserved Pennsylvanian strata.

The present study found no convincing evidence for the presence of Carboniferous strata beneath Permo-Trias in the Portpatrick Basin, the southern part of the North Channel Basin complex: the only well to penetrate Permian in this basin (111/15-1) unfortunately terminated in early Palaeozoic rocks having passed through the marginal fault. The absence of Carboniferous strata may be a consequence of erosion following late Variscan inversion on the NNW-trend (see below). However, they are present within re-entrants at the northern edge of the Southern Upland Massif (Stranraer, Strangford Lough), and are certainly present to north of the Southern Upland Fault (Larne, Rathlin basins and SW Arran Trough). All of these basins are very poorly explored by deep boreholes and only very general conclusions can be made about their Mississippian evolution, largely by inference from nearby analogues onshore (Read et al. 2002).

\section{Early phase of Variscan inversion}

Through Pennsylvanian time, the impact of the Variscan Orogeny resulting from the collision of numerous Gondwana-derived terranes (Armorica, Central Massif, Bohemian Massif etc) with the southern margin of Laurussia (Ziegler 1990; Pharaoh et al. 2006) became increasingly evident in Britain. Large-scale northward thrust and nappe emplacement occurred in southern Britain, S Wales and S Ireland, but the region lay in the northern foreland of the Variscan Foldbelt (Besly 1988; Ziegler 1990; Pharaoh et al. 2010). In late Pennsylvanian (Westphalian C) time, an early phase of inversion was followed by deposition of strata of the Warwickshire Group, above a regional unconformity (Eastwood et al. 1937; Akhurst et al. 1997; Jones et al. 2011; Dean et al. 2011; Waters et al. 2011). The Whitehaven Sandstone Formation (equivalent to the Warwickshire Group and of latest Westphalian to ?Stephanian age) has divergent palaeocurrents to the south in Cumbria, and to the north at Canonbie, reflecting penecontemporaneous growth of the Solway inversion anticline (Jones et al. 2011). In the EISB, this study has identified SSW-ENE trending inversion structures parallel to the Eubonia-Lagman Fault System in the north (Fig. 6), as well as in the Môn-Deemster inversion belt described above. The study has shown that the early phase of Variscan inversion structures are cut discordantly by the NNW-SSE to N-S trending faults of the Permian-Mesozoic main graben structures of the EISB, such as the Godred Croven Fault and the western marginal fault of the East Deemster Basin. North of the Ramsey- 
Whitehaven Ridge, both the Solway and Peel basins suffered strong inversion on SSW-NNE 'Caledonoid' trends, with uplift and erosion of most of the post-rift (Namurian to Westphalian) successions, prior to deposition of Warwickshire Group strata (Jackson et al. 1995; Newman 1999). Variscan reversal of the Maryport Fault is demonstrated by the preservation of a much more complete post-rift sequence on its footwall block (Ramsey-Whitehaven Ridge) than in the Solway Basin, its hangingwall block (Chadwick et al. 1993).

\section{Later phase of Variscan inversion}

In late Pennsylvanian time, the final deformation phases of the Variscan Orogeny are associated with the closure of the Uralian Ocean basin and collision of the Kazakhstan and Siberian plates (Zonenshain et al. 1984; Puchkov 1997; Brown et al. 2002), resulting in W-E oriented compressional stress (Coward 1993; 1995). In the study area, inversion occurred along NNW-SSE to N-S trending faults such as the Keys Fault, Gogarth Fault, the western marginal fault of the East Deemster Basin and the Formby Point Fault System. Evidence for this is provided by the Carboniferous subcrop pattern presented by BGS (1994). The Pre-Permian subcrop inset in the marginalia of this map clearly shows erosion of Westphalian strata in NNW- to N-S trending belts associated with the hangingwalls of the Keys Fault (Fig. 5b), Gogarth Fault (Fig. 4a) and Lake District marginal faults (Fig. 5c. By contrast, Westphalian strata are well preserved on the footwall of these structures. The seismic data indicate the presence of N-S trending anticlinal folds cored by Namurian strata, dissected by faulting on their overturned limbs. Similar subcrop patterns, with Namurian subcrops in the cores of Variscan inversion anticlines e.g.. the Murdoch Anticline, are observed in Quadrants 43 and 44 in the southern North Sea (Corfield et al. 1996), and indeed, the two basins exhibit a similar degree of inversion. At present the faults are extensional structures of Permian and younger age; but these are here inferred to have initiated as thrusts on the overturned limb of the anticlines during Variscan inversion, as reported in the Ogham Inlier by Quirk \& Kimbell (1997). Seismic mapping of the subcrop in the present study confirms this pattern and has identified a possible interference structure between the two trends in the Ribble Estuary Inlier (Fig. 6). Although it is conceivable that inversion on faults with both WSW-ESE and NNW-SSE trends could have occurred in one Variscan phase of inversion, comparable to the partitioned deformation system advocated for the Northumberland Basin by De Paola et al. (2005), the above evidence would appear to suggest two phases of nearly orthogonal Variscan inversion are more likely. Extensional reactivation of the NNW- to N-S trending late Variscan inversion structures in W-E extension during Permian to Mesozoic time, facilitated development of NNW-SSE to N-S trending graben of the EISB, strongly discordant to the strong SW-NE structural grain established by Caledonian compression, Mississippian extension and early Variscan inversion. Strong uplift and erosion during the Variscan inversion led to complete removal of the Pennine Coal Measures strata underlying the Lagman Basin. The ancestral Keys Fault played a key role in partitioning the former Eubonia Tilt-block into western and eastern segments, the latter being almost obliterated by post-Variscan events. Inversion on the same trend may have led to uplift and erosion of Carboniferous strata deposited within basins on the North Channel Basin complex.

\section{Post-Variscan structural evolution}

The Post-Variscan structural evolution of the EISB has been thoroughly described in numerous previous publications (BGS 1994; Jackson et al. 1987’ 1995’ 1997; Jackson \& Mulholland 1993). As a result, only a generalised account, focussing on those elements where the Palaeozoic structure has a bearing, will be presented here. Following the Variscan basin inversion and regional uplift described above, there is clear evidence on seismic profiles for the erosion of Pennine Coal Measures strata from the crests of inversion anticlines, and tectonic dissection of the latter adjacent to the Keys, Lagman, Lake District Boundary and Formby Point faults prior to deposition of Permian strata. Jackson \& Mulholland (1993; p793) and Jackson et al. (1997; Figure 2) recognised significant thickening of the Appleby Group (Lower Permian), possibly to as much as $1150 \mathrm{~m}$ (Jackson \& Mulholland 1993), in a belt extending from the Berw Basin to the Formby Oilfield. For example, the well 110/11-1 proved 763 m of Collyhurst Sandstone Formation 
(Appleby Group), while 110/7-2 $12 \mathrm{~km}$ to the north proved only $40 \mathrm{~m}$, and none is present in the vicinity of the Morecambe fields. The belt of thick Appleby Group strata directly overlies the Môn - Deemster Foldbelt, providing strong evidence for significant early Permian penecontemporaneous relief within, and deep erosion of, the tectonically weakened inversion belt. The area must have had a substantial topography in early Permian time. It is interesting to note that significant pre-Permian palaeotopography was described at Formby by Falcon \& Kent (1960).

A series of NNW-SSE to N-S trending rifts began to develop in response to W-E extension affecting the crust of the Pangaea Supercontinent that was established during the Variscan Orogeny (Whittaker 1985; Coward 1995; Chadwick \& Evans 1995). In the Worcester and Knowle basins onshore, rifting was able to exploit the N-S ('Malvernoid') grain previously established by late Precambrian orogeny (Pharaoh 1987; Barclay et al. 1997) and subsequent Variscan inversion (Chadwick 1993). The rifts propagated with stepwise, en-echelon offsets through the province, from the Stafford and Cheshire basins and EISB through the Portpatrick and Larne basins and the North Channel to the western Scottish offshore basins (Ziegler 1990). The Solway and Peel basins subsided less than the EISB, and are elongated SW-NE, reflecting structural control by the extensionally-reactivated Caledonide basement structure within the Iapetus Convergence Zone. Nevertheless, it is notable that the majority of small to medium-sized intrabasinal normal faults (Chadwick et al. 2001) take up the new N-S trend, as in the Cheshire Basin (Chadwick 1997). By Triassic time, the EISB was a mature component of the Central European Basin System (Scheck-Wenderoth et al. 2007; Pharaoh et al. 2010), receiving up to 5km fill of Sherwood Sandstone Group clastic sedimentary rocks and Mercia Mudstone Group mudstones and evaporites (Jackson \& Mulholland 1993). Small relict outliers of Lias (early Jurassic) strata in the Carlisle Basin (Warrington et al. 1997), Peel Basin (Chadwick et al. 2001) and EISB (Jackson \& Mulholland 1993) indicate that subsidence continued into Jurassic time. Evidence for mid- and late Jurassic subsidence has been removed subsequent to Cenozoic inversion, uplift and erosion. The magnitude of post-Triassic displacement is difficult to estimate due to this erosion, but it is likely that the Lagman and Keys faults, together with the Maryport, Portpatrick, Loch Ryan and St Patrick faults, suffered significant normal movement (Jackson \& Mulholland 1993; Quirk et al. 1999). Apatite fission-track analysis indicates that for parts of the Ramsey-Whitehaven Ridge, maximum post-Variscan burial was achieved in early Cretaceous time (Green et al. 1997). This was associated with peak generation of hydrocarbons from Carboniferous source rocks throughout the region. Soon after this, a fall in relative sea level and erosion resulted in the Late Cimmerian Unconformity, found throughout the British Isles (Whittaker 1985). The reduction in confining pressure may have been enough to allow early formed hydrocarbons, principally oil, to escape early reservoir structures in gentle roll-over anticlines associated with the shallow detachment tectonics in the centre of the Main Graben, towards roll-over traps at the marginal faults (Pharaoh et al. 2016b).

Opening of the Atlantic Ocean east of Greenland by Paleocene times associated with putative Icelandic Plume activity (e.g. Brodie \& White 1994; Nadin \& Kuznir 1995) resulted in voluminous magmatism in the Inner Hebrides and in N Ireland just to the west of the study area. The Fleetwood Dyke Complex (Kirton \& Donato 1985) was intruded en echelon across the main graben of the EISB. Magmatic and thermal processes on a lithospheric scale resulted in regional thermal doming of the crust below the EISB (White 1988) in Palaeogene or possibly, late Cretaceous, time (Cope 1994, 1997). Across the study area, the combination of enhanced regional and local heat flow led to a further phase of hydrocarbon generation (Cowan et al. 1997; Meadows et al. 1997). Superimposed on the regional, thermal uplift described above were the effects of later crustal shortening, associated with the developing Alpine Orogeny in southern Europe. Apatite fission-track data indicate a second Cenozoic phase of cooling at 25-20 Ma (Newman 1999), compatible with the region being affected by the Oligo-Miocene phase of inversion found in southern Britain and the southern North Sea (Van Hoorn 1987; Badley et al. 1989; Chadwick 1993). Inversion of the Solway Basin led to development of a major anticlinal structure in the hangingwall block of the Maryport Fault (Chadwick et al. 1993) on the northern side of the Ramsey-Whitehaven Ridge. On the southern side of the ridge, the reversal of the Lagman Fault led to the 
generation of small hangingwall anticlines (Chadwick et al. 2001). Flower structures and 'pop-up' structures are found along the Keys Fault and Formby Point Fault e.g. the Rhyl and Lennox fields (Haig et al. 1997), reflecting the 'buttressing' effect of the margins of the EISB (Pharaoh et al. 2016b). Throughout the EISB, seismic data indicate the presence of gentle Cenozoic inversion anticlines (Figs. 4a, b, c) superimposed on an earlier generation of Variscan inversion anticlines (Pharaoh et al. 2016a; b), the 'posthumous' tectonic style recognised by Jackson \& Mulholland (1993). Further tightening of the Variscan inversion anticlines during Cenozoic (Alpine) crustal compression resulted in the development of more open structures in the Permo-Triassic cover. This was likely an important process in the generation of the traps in the Hamilton fields (posthumous upon the Môn-Deemster inversion belt) and the Millom, Dalton and Calder fields (posthumous on the Keys-trend of latest Variscan inversion).

\section{Petroleum systems of the Carboniferous basins of the EISB}

In the EISB, a proven petroleum system is present, involving a Carboniferous source (Colter \& Barr 1975; Cowan 1991; Stuart 1993; Armstrong et al. 1997), reservoirs of the Ormskirk Sandstone, locally the uppermost formation of the Triassic Sherwood Sandstone Group, and halite seals (Fig. 7). A substantial number of exploration wells have been drilled, but few penetrate the Permian and the potential pre-Permian resource underlying the EISB fields is poorly known. The North and South Morecambe gasfields (Fig. 6), with a combined in place recoverable of 5.2 tcf (Cowan 1996), were discovered in the 1970s and lie in large regional anticlines associated with rollover and salt-facilitated low angle detachment faulting, of Triassic to Jurassic age (Knipe et al. 1993). Further modification of trap geometry occurred in Miocene time as a result of Alpine inversion. An initial charge of hydrocarbons (probably mostly oil) in Jurassic time was originally thought to have been derived from Pennine Coal Measures source rocks, as in the southern North Sea (Bushell 1986). Subsequently the Bowland Shale Formation was confirmed as the source (Armstrong et al. 1997). This early charge was associated with the formation (at about $180 \mathrm{Ma}$ ) of a 'platy-illite' layer, interpreted as a palaeo-hydrocarbon-water contact (Bushell 1986; Woodward \& Curtis 1987; Knipe et al. 1993), which was lost during the early Cretaceous and the present (mostly) gas charge is believed to result from a further cycle of hydrocarbon generation (also from the Bowland Shale Formation?) associated with an elevated geothermal gradient during the early Cenozoic (Cowan \& Bradney 1997). Hydrocarbon migration continues in the basin to the present day, as witnessed by the seepage of oil into Quaternary sands and peats at Formby, on the Lancashire coast.

In the 1990s, the Hamilton, Douglas, and Lennox fields, with a mixture of oil and gas, were discovered parallel with the North Wales coast in the southern part of the EISB (Fig. 6). Most of the deep wells of these fields encountered Millstone Grit Group below the Variscan Unconformity, as at Formby. Using isotopes the sampled oils (from 110/15-6, Lennox and 110/13-10, Douglas Oilfield) were correlated with each other, and the Holywell bitumen and the Holywell Shales (correlative of the Bowland Shale Formation) of NE Wales thereby proving the Bowland Shale source (Armstrong et al. 1997). These were isotopically lighter (more negative) than Westphalian cannel coals of Type I kerogen, for example those formerly mined and used to make oil at Leeswood in North Wales (Falcon \& Kent, 1960) . Waxy crude shows in the Millstone Grit Group in well 110/07b-6 (1510 m-1675 m; Released Geochemical Report) showed an isotopically similar source to shows in wells 110/07-2, 110/08-3 and Formby. The API of the Irish Sea oils range from 40-45 at Lennox and Douglas (Hardman et al. 1993), to 37 at Formby (Armstrong et al. 1997), perhaps suggesting a less mature source in the onshore field. Many additional small fields have been discovered subsequently, mostly in the centre of the EISB and mostly containing gas, culminating with the Rhyl discovery in 2009. In the Irish Sea, no significant Carboniferous reservoirs or good shows have been reported but there is at least one discovery (113/27-2) in the Collyhurst Sandstone (Appleby Group).

\section{Stratigraphy of the petroleum system}

Carboniferous source rocks are shown in Fig. 7, as covering the lower part of the Namurian and highest part of the Visean where shales are developed; Pennine Coal Measures may make a contribution where 
preserved. The lithostratigraphical terminology used here is that introduced by Waters et al. (2011) to better integrate the offshore with the onshore geology than previous schemes (e.g. Jackson et al. 1999). The Carboniferous source rocks are separated from the Triassic Ormskirk Sandstone reservoir rocks by the Millstone Grit Group and, where present, Pennine Coal Measures and Warwickshire groups. Above the Variscan Unconformity the Permian Appleby and Cumbrian Coast groups, and the lower, tight part of the Triassic Sherwood Sandstone Group, also intervene. A Pendleian time slice (Fig. 9) highlights the persistence of the relatively deep marine hemipelagic successions (Bowland Shale Formation) across the central part of the British Isles, including the Craven Basin, EISB and westward towards the Dublin Basin (Ramsbottom et al. 1969; Cope et al. 1992; Jackson \& Mulholland 1993; Wakefield et al. 2016). The late Pendleian saw the first major influx of thick fluvial and deltaic sandstones into the Craven Basin, both from the north and from the south. The northern basin fill are characterised by a thick pro-deltaic ramp turbidites, overlain by a siltstone-dominated slope succession, in turn overlain by a fluvio-deltaic, deltatop sandstone (Collinson 1988; Wakefield et al. 2016). The hemi-pelagic successions have gamma values which suggest potential as source rocks. The overlying successions of the Pennine Coal Measures and Millstone Grit groups have potential as a combined source-reservoir unit, with secondary sources from marine influxes and coaliferous sediments.

Clastic intervals within the Carboniferous and Permian successions that are evaluated for reservoir potential include the Appleby Group, Warwickshire Group, Pennine Coal Measures Group, Millstone Grit Group and Bowland Shale Formation. The Carboniferous Limestone Supergroup has been assessed as a potential reservoir, although the effect of secondary, karstified and fracture porosity has not been analysed. The preservation and thickness of the possible reservoir units is variable, particularly the Carboniferous units beneath the Variscan Unconformity (Fig. 6). Interpretation of well logs and associated core analyses (biostratigraphy, poroperm etc) frequently provide alternative stratigraphic interpretations to those shown on the well composite log, and have been carried out in this study (Fig. 9a, b). Many authors have referred to the problems in identification that results from secondary reddening of the Carboniferous strata below the Variscan Unconformity (Trotter 1954; Falcon \& Kent 1960; Jackson et al. 1995) in both the adjacent onshore and within the EISB. In the south of the basin, thick Appleby Group strata overlie the Variscan Unconformity and stratigraphic interpretation is straightforward. However, in the Morecambe fields area, the Appleby Group is absent and the Cumbrian Coast Group is interpreted to overlie the Variscan unconformity (Fig. 9b). This is important because it shows the probable topography of the Carboniferous surface, deformed and uplifted by the Variscan Orogeny, and the extent of erosion and eventual burial. The Cumbrian Coast Group comprises a varied sequence of thin sandstones, anhydrites, limestones, halites and mudstones, mostly red in colour. Underlying redbeds have therefore been interpreted either as a mudstone facies of the Appleby or as Warwickshire Group strata, on well composite logs. The favoured interpretation, combining all the seismic and well evidence, is that the red beds directly underlying the Cumbian Coast Group are secondarily reddened. They often include thin sandstones and high gamma shales and rarely contain coals, and are believed to be mostly of Namurian depositional age.

\section{Source rocks}

One of the key risks in the Palaeozoic of the greater Irish Sea province is the quality, extent and maturity of source rock intervals. Potential source rocks include coals of the Pennine Coal Measures (Westphalian) and upper Millstone Grit (Namurian) groups; shales of the Bowland Shale Formation and Millstone Grit Group (Pendleian and Arnsbergian); and older Visean shales (unproven by sample data), for example in the lower part of the Yoredale Group. Compilation of the Rock-Eval source rock geochemical data from released legacy reports revealed a small data set (264 samples), limiting the analysis which could be undertaken (Vane et al. 2016). Where penetrated, the Pennine Lower Coal Measures Formation, Millstone Grit Group and Bowland Shale Formation are mainly gas-prone strata with poor-fair remaining generative potential, and are mature to the gas window at the sampled intervals in Quadrants 110 and 113 (Vane et al. 2016). Some shales within the Millstone Grit Group have TOC values (Fig. 11f) and S1 hydrocarbon values (Fig. 11a) greater than the Bowland Shale Formation. Given the maturity levels, 
source rock potential in these wells is likely to have been depleted by hydrocarbon generation, or the original quality of these source rocks was poor to fair. The Cumbrian Coast Group, Appleby Group and Carboniferous Limestone Supergroup sampled in two wells in Quadrant 111 are oil to gas window mature, but have low Total Organic Carbon (TOC) and low residual hydrocarbon generative potential. Data is generally lacking to characterise kerogen types using a Van Krevelen plot, however data from well 110/02b-10 (Fig. 11b) suggests a kerogen mix between Type II and III for the Millstone Grit Group and Pennine Coal Measures. A similar mixed system can also be expected for the Bowland Shale Formation but with a higher proportion of Type II kerogens. The high TOC and widespread extent of the Bowland Shale Formation favour it as the primary source rock, at least in the southern part of the Irish Sea. The other potential sources are ranked as secondary to this.

\section{Hydrocarbon maturation and generation}

Vitrinite reflectance data (Fig. 11d) shows that the Bowland Shale source rocks in wells are mature for oil and gas generation (Corcoran \& Clayton 1999; Vane et al. 2016). EISB oils were considered to have been derived from the source in the range $0.75-0.85 \%$ Ro maturity, and the condensate from $>1.0 \%$ Ro (Armstrong et al. 1997). Given the structural complexity for the area of interest, a singular burial trend and maturity profile cannot be defined. Cowan et al. (1999) gave examples of varying thermal and burial history at the basin margins changing over tens of kilometres. Three wells show a correlation of maturity increase with depth within the $\mathrm{T}_{\max }$ dataset: 110/07b-6, 110/02b-10 and to a lesser extent 113/27-1, indicating progressive oil window into gas window maturity with depth. Some of the $T_{\max }$ data indicate a wide spread of temperatures at the same depth, perhaps reflecting reworked and caved material in addition to in situ measurements or possibly due to $\mathrm{T}_{\max }$ suppression caused by variable kerogen and free oil composition (Fig. 11c). Onshore Isle of Man boreholes (Shellag, Ballavarkish, Black Marble Quarry; Fig, 5) show a similar range of $T_{\max }$, albeit with few samples (Racey 1999).

\section{Basin modelling}

A lack of preserved post-Jurassic strata has resulted in a range of burial and thermal models for the EISB, for example Cenozoic uplift estimates ranging from $<1 \mathrm{~km}$ to up to $3 \mathrm{~km}$ (Cowan et al. 1999; Quirk et al. 1999 and references therein). In this study, well 110/07b-6 was chosen for burial and thermal modelling as it had the most complete geochemical profile and thick Carboniferous section (Gent 2016; Fig. 12). The well is situated on a minor Variscan structural high, and is considered reasonably representative of the more marginal areas of the basin. The burial model was matched to the measured vitrinite reflectance (VR) profile and the calculated VR profile (from $\mathrm{T}_{\max }$ ) (Fig. 12). Using published studies (Cowan et al. 1999; Quirk et al. 1999) and seismo-tectonic interpretations from this study a 700 $\mathrm{m}$ uplift event in the late Carboniferous, followed by a minor $150 \mathrm{~m}$ uplift during development of the Late Cimmerian Unconformity, and a final $1100 \mathrm{~m}$ uplift and increase in palaeo-heatflow in the Cenozoic were included. The modelling shows that burial of the Bowland Shale Formation source rock in the Carboniferous resulted in the early-mid mature oil window being reached, before uplift and subsequent deeper burial in the early Cenozoic, just reaching main gas generation in the base of the drilled strata (Fig. 12). This is consistent with the oil shows documented in the well geochemical report (Geochem Laboratories Ltd 1988). Carboniferous trap formation, migration and generation were all likely to have occurred during the Variscan Orogeny. However, subsequent uplift would have almost certainly breached the traps. Migration and trap formation was renewed in the Mesozoic and Cenozoic, with any modern day hydrocarbon accumulations required to have survived the potential structural breach as a result of Cenozoic inversion.

\section{Migration}

Migration of hydrocarbons into Triassic reservoirs and traps has clearly been successful as evidenced by the producing oil and gas fields of the EISB. Oil migration to the Triassic Hamilton fields may have occurred, vertically along faults, in Jurassic and Cretaceous times (Yaliz 1998; Haig et al. 1997; Yaliz \& Taylor 2003). This study has highlighted how these fields overlie the Môn-Deemster inversion belt 
described above (Fig. 6), the structures of which may have acted as first stage reservoirs, subsequently breached to allow migration into overlying Triassic traps, formed posthumously as late as Cenozoic time, on a template created by the Variscan inversion structures. In a similar way, the Millom, Dalton and Calder fields, lying close to the Keys Fault, and Lennox Field, close to the Formby Point Fault, are Cenozoic age traps formed posthumously on a template provided by the second phase of Variscan inversion structures. As the basin depocentre widened and new areas came into the oil window, additional hydrocarbons may have been generated and continued to migrate southward. The basin depocentre within the dismembered Eubonia Tilt-block entered the gas window and gas migrated into the Morecambe and other fields. This may have occurred both pre- and post-Late Cimmerian uplift/sea-level fall (Bushell 1986). In a conceptual Carboniferous petroleum system model, migration is away from the steadily deepening and expanding hydrocarbon kitchen towards the margins of the basin, where these strata fail by thinning and overlap. In the north the boundary is strongly faulted (Lagman, Eubonia and Lake District boundary faults).

\section{Characteristics of potential reservoirs}

A reservoir evaluation of Permian and Carboniferous intervals, designed as a quick-look regional overview, was based on legacy core plug-measured porosity and permeability data and continuous petrophysical interpretations for 8 wells (Hannis 2016). Net-to-gross, porosity and basic permeability estimates were calculated for each formation, summarised in Table 1. In general, the results illustrate fairly low net to gross values of less than 10\% (except in the Permian-aged Appleby Group where net-togross was 79\%), porosities (highest formation averages mostly around $10 \%$ but up to $19 \%$ in the Appleby Group) and mainly poor average permeabilities (highest formation averages mostly less than 10 $\mathrm{mD}$ ). Further examination of the distribution of potentially higher permeabilities within the Millstone Grit sandstone intervals could be worthwhile (Table 1). The core plug measured porosity versus permeability data by formation is exhibited in Fig. 13.

The aeolian-dominated Permian Appleby Group strata that include the Collyhurst Sandstone are a prospective reservoir interval. The group as proven in well data is commonly defined by a basal breccia, overlain by a thick clean sequence of aeolian sandstones, culminating in an upper sequence of breccias (Wakefield et al. 2016). Based on 6 wells in Quadrant 110 in the depth range 1300-2400 m, maximum measured core porosity is $21 \%$ with a highest formation average in all wells of $13 \%$. Permeability is however poor, with a maximum measured permeability of $71.5 \mathrm{mD}$ (vertical $\left(\mathrm{k}_{\mathrm{v}}\right)$ ), and a highest formation average of $0.8 \mathrm{mD}$ (horizontally, $\mathrm{k}_{\mathrm{h}}$ ) and $7.90 \mathrm{mD}$ (vertically). Petrophysical analysis has confirmed the group as being a sandstone-dominated interval with an average net-to-gross ratio of $79 \%$. Petrophysical porosity and permeability calculations match with the core-measured values, with the highest average porosity calculated at $19 \%$ and highest average permeability estimates of $6.89 \mathrm{mD}$, with some estimates in the 50-100 mD range for several wells (Table 1 and Hannis 2016).

The Warwickshire Group is the equivalent of the Ketch and Boulton formations of the southern North Sea in Quadrant 53 and Quadrants 43-44 (Waters et al. 2011). Onshore, the Warwickshire Group of North Wales and Cheshire Basin comprises predominantly red, brown, purple-grey mudstones and sandstones and locally green-grey siltstones and mudstones with thin coals. However, potential reservoir sandstones can be locally significant. The amount of sandstone relative to mudstone and siltstones within constituent formations of the Warwickshire Group varies considerably. In West Cumbria, the Whitehaven Sandstone Formation, at least 280 m thick (Akhurst et al. 1997; Dean et al. 2011) is mainly a red to deep purple or purplish brown, cross-bedded, micaceous, medium- to coarse grained sandstone (Wakefield et al. 2016). The Halesowen Formation was productive in the small mined Coalport Tar Tunnel 'field' in Shropshire during the $18^{\text {th }}$ and early $19^{\text {th }}$ century (Smith et al. 2005). In the East Midlands, the Warwickshire Group group has been documented to have better reservoir characteristics than productive older late Carboniferous strata, but was spatially confined to the synclines (BGS 1984; Pharaoh et al. 2011). Data from Quadrant 53 and the English Midlands shows that an average porosity of $16 \%$ is likely, with a permeability of several hundred $\mathrm{mD}$, although the bulk of the data was from above $600 \mathrm{~m}$ depth. Therefore investigation of the Warwickshire Group as a reservoir interval offshore was considered, 
though seismic mapping indicated a limited extent in the greater Irish Sea province (Fig. 6) and there are no well penetrations and therefore no reservoir data for the group. However, Bolsovian-Asturian (Westphalian C-D) age strata are recorded in well 33/22-1 along strike in the Kish Bank Basin (Jenner 1981).

In the EISB, the Pennine Coal Measures Group comprises interbedded grey mudstone, siltstone and pale grey sandstone, commonly with mudstones containing marine fossils in the lower part of the lower and upper part of the middle subdivisions, and more numerous and thicker coal seams in the intervening interval. The group shows an overall blocky to erratic log response, with thick high gamma mudstone and siltstone intervals and relatively thin $(3-15 \mathrm{~m})$ low gamma sandstones. The sandstones show considerable variation in wireline log character, including 'boxcar' motifs in thick, distributary channel sandstones (Wakefield et al. 2016). Onshore, sandstones are also frequently encountered (e.g. Cefn Rock and Hollin Rock of NE Wales coalfields, Worsley Delf Rock, Prestwich Rock and Newton Rock of Lancashire Coalfield) and are approximate equivalents to the productive sandstones in basinward East Midlands fields (e.g. Oak Rock, Crawshaw Sandstone, Wingfield Flags). Based on five wells in Quadrants 110 and 113, in the depth range 1400-3050 m, maximum measured core porosity is $10 \%$ with a highest formation average in all wells of $6 \%$. Permeability is generally poor with a maximum measured horizontal permeability of $9.43 \mathrm{mD}\left(\mathrm{k}_{\mathrm{h}}\right)$, and a highest formation average for $\mathrm{k}_{\mathrm{h}}$ of $1.07 \mathrm{mD}$. Petrophysical analysis of the Pennine Coal Measures Group provides a similar outlook, with an average net to gross of $9 \%$. Net intervals have reasonable porosities, with the highest average porosity at $11 \%$. Permeability is generally poor with the highest average permeability estimated at $0.8 \mathrm{mD}$. However, permeability up to $61 \mathrm{mD}$ was estimated in one well (110/02b-9; Table 1, Hannis 2016).

The Namurian-aged Millstone Grit Group comprises cyclic sequences of quartzo-feldspathic sandstone, grey mudstone, thin coal and prominent seatearths, resulting from deposition by repeated progradational deltas (Collinson 1988). Common marine bands are present and represent discrete flooding events (Waters \& Condon 2012). Thick reservoir intervals are uncommon, with initial turbidite lobes passing into delta-top deposits with thin sandstones typically contained within sheetfloods, overbank deposits and stacked channels. Onshore, and potentially offshore, thicker sandbodies (up to 50m thick) occupy incised valleys (Waters \& Condon 2012; Wakefield et al. 2016). Jackson et al. (1997; Figure 6) identified a Kinderscoutian sandstone unit up to $90 \mathrm{~m}$ thick in the Liverpool Bay region (111/20-1), which can be correlated with wells farther north (112/30-1 and 113/27-2) although considerably reduced in thickness. Onshore, Millstone Grit sandstones are encountered in NE Wales (e.g. Cefn-y-Fedw, Gwespyr Sandstone, Aqueduct Grit), Lancashire (e.g. Fletcherbank Grit, Pendle Grit and Warley Wise Grit), and in producing East Midland fields (e.g. the Rempstone Oilfield). The Namurian (Marsdenian) depocentre extends from the Staffordshire Gulf, probably to Preston and thins to SW under the Cheshire Basin (Collinson et al. 1977; Smith et al. 1995). This pattern continues into the offshore of the EISB with Namurian absent at the Rhuddlan well on the North Wales coast (Figs. 5, 9b). Based on samples from four wells in Quadrants 110 and 113, at 1950-3550 m depth, maximum measured core porosity is $10 \%$ with a highest formation average in all wells of $6 \%$ (Table 1). Permeability is poor, the maximum measured was $0.37 \mathrm{mD}\left(\mathrm{k}_{\mathrm{h}}\right)$, and the highest formation averages for $\mathrm{k}_{\mathrm{h}}$ and $\mathrm{k}_{\mathrm{v}}$ were $0.04 \mathrm{mD}$ and $0.05 \mathrm{mD}$ respectively. Petrophysical analysis provides a more promising outlook for the group, although the average net-to-gross is $10 \%$. Net intervals have a reasonable porosity, the highest average porosity is 11 $\%$. Permeability is poor with an average estimate of $0.2-2.1 \mathrm{mD}$, apart from one well $113 / 27-2$, which shows an average of $367.7 \mathrm{mD}$ (Table 1). Further analysis of these sandstones could therefore be beneficial (Hannis 2016).

The Bowland Shale Formation is only examined in the wells 110/11-1 and 110/07b-6, however the formation broadly shows an upwards decrease in carbonate turbidites and an increase in siliciclastic sandstone turbidites (Wakefield et al. 2016). Potential thin reservoir sandstones may be present. Well 110/07b-6 encounters a total of $16 \mathrm{~m}$ of these sandstones, giving a net-to-gross of $3 \%$. (The other well examined, 113/27-2, contained no net intervals). No core samples were taken, but petrophysical interpretation revealed that the net intervals had porosities up to $23 \%$, although the average porosity was 7 
\%. Permeability estimates appear poor with an average of $0.7 \mathrm{mD}$ and maximum of $16.2 \mathrm{mD}$ (Table 1 , Hannis 2016).

Carboniferous Limestone Supergroup sequences are interpreted to be widespread over the EISB and thus worthy of investigation as a reservoir. Petrophysical analysis of the limestones encountered in two wells (112/25a-1 and 111/25A-1) appear clean, but have too low matrix porosities (less than $5 \%$ ) to be considered as a reservoir (Table 1), but accumulations could be hosted in secondary porosity as a result of karstfication or fracturing. Onshore, the Hardstoft Oilfield in Derbyshire (Craig et al. 2013) produced from the top of the Carboniferous Limestone, but despite numerous shows, no further production was established from this reservoir in the East Midlands fields (Falcon \& Kent 1960). Karstified limestones such as those known from Anglesey (Walkden \& Davies 1983) and apron reefs like those which crop out at Castleton, Derbyshire might be present in the offshore. Seismic evidence for the possible presence of reefs towards the top of the ramp of the Eubonia Tilt-block in Quadrant 109 (Fig. 4a) was described above and indicated schematically in Fig. 4a. Waulsortian mud-mounds of pre-Asbian age may also be possible reservoirs. They are seen at outcrop in the south of the Isle of Man (Dickson et al. 1987) and in the Craven Basin. In the prolific Williston Basin of Canada, collapsed mud-mounds up to $100 \mathrm{~m}$ tall provide excellent porosity but were initially hard to identify on seismic data (Kupecz et al. 1996).

\section{Seal rocks}

The Cumbrian Coast Group, which includes the Manchester Marls (Fig. 7), provides the most extensive potential seal to Permian or Carboniferous rocks across the whole of the greater Irish Sea area. The unit consists of thick evaporites in the north and central East Irish Sea, thinning southward, passing laterally into dolomitic mudstones (Jackson \& Mulholland 1993; Wakefield et al. 2016), and is encountered in wells in surrounding sub-basins. This seal has been proven to trap hydrocarbons in the well 113/27-2, and sealing potential is proven in 112/25a-1, with minor gas shows in the tight Appleby Group. In the producing EISB fields, any Cumbrian Coast Group seals were breached as the fluids migrated out of the Carboniferous and Permian into the Triassic Ormskirk Sandstone reservoir (Colter 1997). Carboniferous intraformational mudstone seals have proved adequate in all the onshore fields of the East Midlands (Pharaoh et al. 2011), Cousland in Scotland (Hallett et al. 1985), various fields in the Silver Pit and Cleaver Bank basins of the southern North Sea and numerous fields in the Netherlands and Germany (Pletsch et al. 2010), and could be expected to work in Carboniferous basins of the Irish Sea.

\section{Hydrocarbon prospectivity of the Carboniferous basins outside the EISB}

Whilst basins of the greater Irish Sea province outside the EISB have extensive seismic coverage of variable quality, there are few wells. Data is therefore lacking to constrain their hydrocarbon systems and is heavily dependent on onshore analogues.

\section{Solway Basin}

The Permian - Jurassic Solway Basin, linked NE to the Carlisle Basin and SW to the Peel Basin is underlain by a Carboniferous basin of the same trend, an extension of the Northumberland Trough (Chadwick et al. 1995; Fig. 2). Two well penetrations (112/15-1 and 112/19-1) prove a Visean Namurian Yoredale Group distinguished from the Carboniferous Limestone Supergroup by the presence of fewer carbonates (Fig. 7). The Yoredale Group sandstones, limestones and siltstones represent a fluviodeltaic depositional environment (see Wakefield et al. 2016) which is a northward lateral equivalent of the basinal Bowland Shale Formation, i.e. the Bowland Shale facies is not proven and may not be present. The presence of delta-top lacustrine facies is a possibility, but has not been demonstrated. In the onshore Cumberland Coalfield, the coals are gassy (Colter 1997), but the Pennine Coal Measures Group have not been penetrated offshore in the Solway Basin. Potential Carboniferous reservoir intervals include a relatively small area of Warwickshire Group on both sides of the Maryport Fault (Figs. 5a, 6) and the Fell Sandstone Formation in the main part of the basin. 


\section{Peel Basin}

The Peel Basin is a Permian-Jurassic basin lying between the Isle of Man and Northern Ireland, underlain by a Carboniferous carbonate platform. Wells 111/25a-1 and 111/15-1 penetrated the Mississippian age Carboniferous Limestone Supergroup, in contrast to the time-equivalent Yoredale Group encountered in the along-strike, Solway Basin. The lack of a clastic, fluvio-deltaic system may enhance the likelihood of the Bowland Shale (source rock) equivalent being present in younger strata between 111/25a-1 and the Isle of Man coast, but there is no data to test this hypothesis. The seismic reflection data are generally of poor quality, but allow the presence of a small outlier of Namurian strata to NW of the Isle of Man. The Peel Basin may extend to the Carlingford Lough area near the Irish border, south of the Mourne Mountains (Fig. 2). BGS boreholes (in Quadrant 112, near the Irish coast) 73/65 and 73/67 are of probable Visean age and form a rim to the Lower Palaeozoic Longford-Down Massif. BGS borehole 71/43 near the Isle of Man coast was dated as Namurian. The data available preclude evidence of a working Palaeozoic petroleum system in the Peel Basin, a conclusion previously reached by both Newman (1999) and Quirk et al. (1999).

\section{North Channel Basin}

The North Channel Basin is a NW-trending Permo-Triassic basin complex lying between the Southern Uplands and the Longford-Down Massif of N Ireland (Quinn 2008) and forms the main rift through the massif. Two tilt-blocks, the E-dipping Portpatrick and W-dipping Larne sub-basins, recognised by Maddox et al. (1997), are separated by the Southern Upland Fault (Fig. 2). Several smaller basins lie parallel in Scotland (Stranraer, Lochmaben) and Ireland (Strangford Lough). In the Portpatrick Sub-basin, the underlying strata are possibly Devonian, although the seismic is poorly resolved because the only well (111/15-1) passed through a fault adjacent to the Southern Uplands, and did not prove a Carboniferous section. Data is lacking for the presence of source, reservoir and seal in this area (Maddox et al. 1997). Permo-Triassic and underlying Devonian and Carboniferous strata are present onshore in the Larne and Lough Neagh basins of N Ireland. Onshore in the Midland Valley of Scotland and in N Ireland a range of potential Carboniferous source rocks (coals, carbonaceous mudstones) and sandstone reservoir intervals are documented, though there is considerable spatial variability (Browne et al. 1999; Read et al. 2002; Underhill et al. 2008; Reay 2004; 2012). Onshore in N Ireland, a Carboniferous prospect was drilled by Infrastrata plc in Woodburn Forest in 2016, without success (website). Seismic interpretation offshore (Pharaoh et al. 2016a) has included a Carboniferous succession in the Larne Basin buried to $5000 \mathrm{~m}$ and with faulting and folding observed offering potential for structural traps. However the interpretation is poorly constrained by data, precluding detailed assessment of petroleum system elements.

Brief mention can be made of the Rathlin Trough, which lies outside the study area, and for which only limited seismic data, covering the offshore extension of the Machrihanish Coalfield, have been studied. The source rocks include coals and oil shales (Murlough Bay Formation) of early Carboniferous age which have excellent TOC and which are mostly in the oil window, with smaller areas in the gas window (Reay 2012).This sequence together with volcanic rocks invites comparison with the Lothian part of the Midland Valley of Scotland (Read et al. 2002). Drilling took place at Magilligan in the west of the basin and at Ballinlea in 2008. In the latter well, oil was produced from the Carrickmore Formation sandstones (Providence 2013) of the wide Visean subcrop (Smith 1985).

\section{Petroleum system knowns and risks}

The distribution of the principal Carboniferous source rock (Bowland Shale Formation) as inferred from the seismic interpretation is constrained by a few borehole penetrations in the EISB, but the absence of boreholes in the deepest part of the basin (Keys and Lagman basins) and onto the Manx-Furness Ridge means that the northern limit is poorly constrained. The nature of the transition to the Solway Firth and Northumberland basins, where boreholes prove time-equivalent Yoredale facies is therefore poorly known. The lack of any offshore well data requires analogy with the adjacent onshore Carboniferous 
source rocks may also be present in the Clyde basins and adjacent North Channel Basin, but are unlikely to be present in the southern part of the latter, or beneath the Peel Basin. Attenuation of the Carboniferous sequence southwards towards the Welsh Massif (Fig. 4b, 9a) also increases the source risk in this direction. The paucity of data on the maturity of the source means that this parameter cannot be mapped in detail. Similarly, the reservoir porosity-permeability characteristics are poorly known over large parts of the region studied. The petrophysical analyses presented here suggest that the Carboniferous sandstones beneath the Morecambe fields have very poor porosity and permeability, confirming information provided by Centrica (pers. comm. 2015). This is no doubt a consequence of their deep burial, and processes such as platy-illite development and silica cementation which severely affect even the overlying Triassic formations (Colter 1989; Bushell 1986; Woodward \& Curtis 1987; Cowan 1991; Stuart 1993). Extensive carbonate platforms surrounding the Isle of Man (Manx Platform) and off North Wales (Colwyn Platform) also have unknown poroperm characteristics. Until more is known about possible secondary porosity (following dedolomitisation) and fracture density, the reservoir properties of these areas are ranked as high risk.

The Mercia Mudstone Group is a proven caprock to Sherwood reservoirs and is present throughout the EISB but is absent across the margins of the basin complex. The potential seal of the Permian Cumbrian Coast Group sequence thins and fails in the same directions. In the EISB a relatively thick shale and evaporite (St Bees Evaporites, Cumbrian Coast Group) may be developed. The same is true in the Portpatrick and Larne basins, where several Triassic halites are present (Quirk et al. 1999; Quinn 2008).

Analysis of seismic data, integrated with well, core data etc, indicates that the marginal areas of the EISB hold the greatest potential for undiscovered hydrocarbon resources in the Carboniferous, although the geochemical, petrophysical and other essential data are scant. In general, the presence of an effective seal is considered to represent the biggest risk in the hydrocarbon system at the margins of the EISB. Yet-to-find prospects are anticipated to be relatively small in volume and with shallow column heights supported by Carboniferous intra-formational seals. The most prospective parts of the region, outside the Triassic play, are considered to be:

- Thick Westphalian combined reservoir and source rock sequences preserved in the Eubonia Tiltblock in Quadrant 109 (Fig. 4a), located outside the main Permian-Mesozoic graben system and less affected by Cenozoic inversion. The presence and quality of seals form a major risk as the Cumbrian Coast Group seal is thin or absent and Carboniferous intraformational seals are required but untested. Based on the limited dataset available in adjacent basins, reservoir quality is also a significant risk.

- A belt of Variscan inversion structures (the Môn-Deemster Foldbelt; Fig. 4b) correlated with structures on the Formby Platform, and the onshore Ribbledale Foldbelt, from which hydrocarbons sourced by a thick Bowland Shale sequence have leaked into the overlying, Triassic-hosted Hamilton fields (block 110/13). The biggest risk here is whether reservoirs exist and remain unbreached at the pre-Permian level, and retain good poro-perm characteristics at depths of about $2500 \mathrm{~m}$.

- A more speculative play lies in the extensive carbonate platform in Quadrant 109 and surrounding the Isle of Man (Fig. 4a), in Asbian reefal facies with enhanced secondary porosity. Here, source rock presence and migration pathways, reservoir properties and seal quality are major risks.

- The Ribble Estuary Inlier east of the Formby Point Fault (Figs.5c,6) may contain a working petroleum play. It lies adjacent to the deep Deemster Basin where there is a thick sequence of Upper Carboniferous sedimentary rocks preserved, and between the Formby and Lennox fields. 
Well 110/9-1, within the Deemster Basin was dry, but appears to have good porosity in the Ormskirk Sandstone though no shows. Fluorescence was recorded in the Appleby Group.

- A potential play exists sourced from the Bowland Shale Formation in the deep Godred Croven Basin drilled by 110/11-1emigrated into the Carboniferous reservoir on the faulted highs of its flanks. The Ormskirk Sandstone is very shallow in these locations but the Carboniferous strata might be securely sealed by the Cumbrian Coast Group.

\section{Discussion}

The pre-Permian structural synthesis presented here is speculative in view of the limited number of offshore well penetrations of Carboniferous strata. For example, further tectonic partitions may exist within the inferred Eubonia Tilt-block. It is possible, for example, that the eastern part of the structure (underlying the Keys and Tynwald basins of the EISB) may represent a separate tilt-block with a hinge in the Lake District Boundary Fault System, and a master controlling fault in the west (ancestral Keys system). The presence of such a basin, referred to as the Lancaster Fells Basin, was inferred by Cowan et al. (1999). However, the available evidence suggests that the NNW structural trend did not play a significant role until latest Carboniferous time, so that an ancestral Keys Fault is regarded an unlikely Visean structural element. The nature of the link between the structures of Quadrant 109 and onshore Lancashire has been much speculated on in the past (e.g. Ramsbottom et al. 1978). Jackson \& Mulholland (1993) recognised the Menai Strait-Pendle Line link, but preferred to link the Q109 Arch to the High Haume Anticline of the Furness Inlier, in the southern Lake District. This paper shows that the Ribblesdale Foldbelt does extend west of the Leyland Basin and Formby Point Fault (c.f. Jackson \& Mulholland 1993; Figure 4 and p797) and links to the Q109 Arch, via the Môn-Deemster Foldbelt. More detailed seismic mapping of the Upper Carboniferous interval will be required to elucidate what is probably an intricately folded subcrop pattern here. We support the proposed continuity of the Bowland Basin southwestwards into the offshore area, as inferred by Corfield et al. (1996) and Cowan et al. (1999). From the perspective of hydrocarbon prospectivity, the presence of the prolific Bowland Shale Formation source rock interpreted across much of the EISB has been a key element in the hydrocarbon system of the overlying Permian to Mesozoic basins. Prospective reservoir intervals with moderate porosity are likely to exist in the Warwickshire Group and Pennine Coal Measures Group in the marginal parts of the EISB, although the permeability is likely to be poor. The EISB lay to west of the main Pennine deltaic and fluviatile fairway in the onshore (Fraser et al. 1990), and consequently shows a lower net/gross sand ratio.

In a review of the deep reflection seismic data for the Irish Sea, principally BIRPS' WINCH lines and some deep data from JEBCO, England \& Soper (1997) state that from this limited dataset, there is no clear evidence for reactivation of earlier structures during either Carboniferous sedimentation or Variscan inversion. Using the shallow seismic reflection data, this study describesthe presence of fold-thrust structures in the pre-Carboniferous basement and, in the Môn-Deemster Foldbelt, demonstrates their role in controlling both Carboniferous extensional and inversion structures. The interpretation presented supports the view of England \& Soper (op. cit.) that the faults controlling Permian and Mesozoic basin development are discordant to the Caledonian, Acadian and early Carboniferous structural grain (as exemplified by the Q109 structures), and are therefore juvenile structures developed in late Westphalian to early Stephanian time. Evidence presented here suggests that these were initiated as a result of a late phase of Variscan inversion, reflecting W-E Uralide compression, superimposed on an earlier phase produced by N-S compression. The timing of these two inversion phases is imprecisely defined in the Irish Sea due to the significant missing stratigraphic section. However, in late Variscide intramontane basins in central France, N-S compression in Stephanian B time is followed by phases of compression on NW-SE (late Stephanian B) and W-E (mid-Stephanian C) principal stress axes (Gélard et al. 1986), the 'Bourbonnaise Phase' of Grolier (1971 Although interpreted in terms of systematic rotation of the 
principal horizontal compressive stress axis Gélard et al. 1986; Blès et al. 1989; Ziegler 1990), Faure (1995) considered these deformations a consequence of late Variscan orogenic collapse. In the UK region, other manifestations of the late $\mathrm{W}$-E compressive phase may include the $\mathrm{W}$-E oriented basaltic dykes, and a component of growth of N-S trending folds, within the Midland Valley of Scotland (Monaghan \& Pringle 2004; Timmerman 2004), and W-E directed transport of fold nappes on the eastern margin of the Worcester Graben (Peace \& Besly, 1997).

The observed variation in Variscan structural orientation in the Variscan Foreland of Britain is currently explained in terms either of one resolved compressional vector (Corfield et al. 1996), or of strain-partitioning across a heterogeneous basement template (e.g. De Paola et al. 2005). In the Irish Sea, it is difficult to argue for a strong control by a N-S oriented basement grain, as identified, for example, within the Midlands Microcraton (Corfield et al. 1996), and the presence of two discrete late Variscan deformation phases is regarded as a more likely scenario. Another expression of the multiple inversion history, and very significant for the formation of Ormskirk traps in the cover, is the impact of posthumous folding. This process, first recognised and described by Suess (1904), is very clearly demonstrated in the Irish Sea, where a template of Variscan inversion anticlines in the Carboniferous sequence underlies structures with similar trend but lower amplitude in the Permo-Triassic cover.

\section{Conclusions}

The study has demonstrated that the basins of the Irish Sea preserve a Phanerozoic geological history as complex as that of the UK onshore. A strong SW-NE structural grain was imprinted on the crust during late Precambrian and Caledonian accretion and orogenic deformation. Dipping zones of strong reflectivity in seismic sections are interpreted as major thrusts and shear zones, some of which can be correlated with known examples onshore. Mississippian rifting on SW-NE trending faults resulted in depocentres which accumulated marine shale source rocks, preceding regional thermal subsidence. The Eubonia Tilt-block is a major Carboniferous syndepositional element beneath the northern part of the EISB, but was partially dismembered by the formation of the ancestral Keys Fault system. The Eubonia-Lagman fault system formed the syndepositional bounding fault to the tilt-block. The Bowland Shale Formation forms the main source rock interval, with inferred thickest development likely just to north of the Môn-Deemster Foldbelt, the offshore correlative of the Bowland Basin, and its inversion, the Ribblesdale Foldbelt. This source rock is buried to depths $>7 \mathrm{~km}$ under the Lagman and Keys basins and is probably post-mature there at the present day.

The Millstone Grit Group and Bowland Shale Formation contain thin clean sandstones locally up to $90 \mathrm{~m}$ thick which could be considered potential reservoirs. Prospective areas at these stratigraphic levels may exist at depth adjacent to the Keys Basin, and west of the Keys Fault. The Millstone Grit Group also has the potential to act as a secondary source rock, as do the Pennine Coal Measures Group when buried deep enough to achieve maturity. However, the latter were stripped from a large area of the EISB following Variscan inversion. Pennsylvanian strata exhibit marked thinning to the south onto the Conwy Platform. Burial by Upper Carboniferous sediments likely resulted in early maturation of kerogen in source rocks within the deepest basins, but destruction of reservoir porosity and permeability in the depocentres. Warwickshire Group sedimentary rocks were not so deeply buried, and are likely to retain better reservoir characteristics.

The Variscan Orogeny, in late Carboniferous time, caused uplift, folding and thrusting on both WSW-ENE (Môn-Deemster) and NNW-SSE to N-S (Keys-Gogarth) trends, probably in two phases, corresponding to well-documented main compressional phases of the Variscan-Uralian Orogen. The later inversion phase occurred on NNW-SSE to N-S trending zones of deformation which would subsequently become localised as the main synsedimentary bounding faults of the EISB in Permian to Mesozoic time. Corfield et al. (1996) provided a definition of inversion intensity. In the greater Irish Sea region, the intensity ranges from moderate (in the EISB, Solway and Clyde basins) to strong, with almost complete 
removal of the post-rift fill (in the North Channel basins and Peel Basin). The timing of these events is poorly constrained in the Irish Sea due to significant missing stratigraphic section, but by comparison with intramontane basins in France, is likely of intra-Stephanian age. The Variscan inversion structures have not yet been adequately tested as targets. They form both first-stage hydrocarbon reservoirs and the structural template for more gentle, 'posthumous' folds produced by Alpine inversion which form traps in the Triassic cover (e.g. the Hamilton fields). Deposition of Permian Appleby Group and Cumbrian Coast Group strata resulted in a potential reservoir - seal combination overlying the Carboniferous source rocks. Permian to Mesozoic rifting is along NNW-SSE and N-S trends. These faults cut discordantly across the early Carboniferous structures and have allowed late Cretaceous to early Cenozoic vertical migration of Carboniferous-sourced hydrocarbons into Triassic reservoirs. There is a migration route to Triassic reservoirs in the centre of the EISB because the Warwickshire Group and Appleby Group strata have been removed from that area, and the thin Cumbrian Coast Group seal breached, where the producing hydrocarbon fields are located. The Clyde-North Channel basin complex, Solway and Peel basins also contain Devonian and/or Carboniferous rocks beneath Permo-Triassic strata, but have likely been buried less deeply than those in the EISB. The North Channel basins may also have suffered significant Variscan inversion. Extensive 2D seismic datasets cover the latter areas but there are only four well penetrations. There have been no discoveries, interpreted to be largely a consequence of the absence of a regional seal comparable in quality to the Mercia Mudstone Group in the EISB. The prolific Bowland Shale source is also absent in these basins, being replaced by fluvio-deltaic sedimentation of the Yoredale Group. Very limited well penetrations do not presently allow a realistic assessment of the prospectivity of the Carboniferous strata underlying these poorly drilled basins.

(Acknowledgements)

This work was undertaken as a joint-industry project for the former Department of Energy and Climate Change (DECC) now Oil and Gas Authority (OGA), Oil and Gas UK and 49 oil and gas company sponsors as part of the 21CXRM (21 $1^{\text {st }}$ Century Exploration Roadmap) Palaeozoic Project. Thanks to Richard Milton-Worsell for his enthusiastic guidance and to the Technical Steering Committee of the project. The role of CGG Geospec, IHS and Western-Geco in supplying regional speculative data for this study is gratefully acknowledged, likewise the provision of data from the CDA and UKOGL data libraries. The staff of Centrica plc are thanked for very helpful and productive discussions. The assistance of the CCS team at BGS, in particular John Williams, in pre-conditioning the well database, was of great help. Mike Sankey is thanked for supplying seismic data from the DECC-OGA digital datastore. Keith Henderson and Sandy Henderson improved the quality of many of the diagrams. Finally, we acknowledge the contribution of the reviewers (Ian Andrews, , , ) in improving the manuscript. This paper is published with the permission of the Executive Director, British Geological Survey. 


\section{References}

AKhurst, M.C., Chadwick, R.A., Holliday, D.W., McCormac, M., McMillan, A.A., Millward, D. \& Young, B. 1997. Geology of the west Cumbria district. Memoir of the British Geological Survey, Sheets 28, 37 and 47 (England \& Wales). (London: HMSO).

ANDREWS, I. J. 2013. The Carboniferous Bowland Shale gas study: geology and resource estimation. British Geological Survey for Department of Energy and Climate Change, London, UK

Armstrong, J. P., Smith, J., D'EliA, V. A. A. \& Trueblood, S. P. 1997. The occurrence and correlation of oils and Namurian source rocks in the Liverpool Bay-North Wales area. In: Meadows, N. S., Trueblood, S. P., Hardman, M. \& Cowan, G. (eds.) Petroleum Geology of the East Irish Sea and Adjacent Areas. Geological Society, London, Special Publications, 124, 195-211.

Arter, G. \& Fagin, S. W. 1993. The Fleetwood Dyke and the Tynwald fault zone, Block 113/27, East Irish Sea Basin. In: PARKeR, J. R. (ed.) Petroleum geology of Northwest Europe: Proceedings of the 4th Conference. The Geological Society, London, 835-843.

Barclay, W.J., Ambrose, K., ChadWICK, R.A., \& PharaOH, T.C. 1997. Geology of the country around Worcester. Memoir of the British Geological Survey, Sheet 199 (England and Wales) (London: HMSO).

Barnes, R.P., Branney, M.J., Stone, P. \& Woodcock, N.H. 2006. The Lakesman Terrane: the Lower Palaeozoic record of the deep marine Lakesman Basin, a volcanic arc and foreland basin. In: BRENCHLEY, P.J. \& RAWSON, P.F. (eds) 2006. The Geology of England and Wales. Second Edition. Geological Society, London, 103-129.

BADLEY, M.E., PRICE, J. D., \& BACKSHALL, L.C. 1989. Inversion, reactivated faults and related structures: seismic examples from the southern North Sea. In: COOPER, M.A., \&WiLliamS, G.D. (eds.). Inversion Tectonics. Geological Society, London, Special Publications, 44, 201219.

BESLY, B. M. 1988. Palaeogeographic implications of late Westphalian to early Permian red-beds. In: BESLY, B. \& KELLING, G. (eds.). Sedimentation in a synorogenic basin complex: the Upper Carboniferous of northwest Europe. Blackie, Glasgow and London, 200-221.

Besly, B. M. 1998. Carboniferous. In: GLENNIE, K. W. (ed.). Petroleum Geology of the North Sea: Basic concepts and recent advances. Blackwell Science Ltd, Oxford, 104-136.

BlÈs, J. L., BOniJOLY, D., CASTAING, C., \& GROS, Y., 1989. Successive post-Variscan stress fields in the European plate (Massif Central and its borders): comparison with geodynamic data. Tectonophysics, 169, 79-111.

BLOW, R. A. \& HARDMAN, M. 1997. Calder field appraisal 110/7a-8, East Irish Sea Basin. In: Meadows, N. S., Trueblood, S. P., Hardman, M. \& Cowan, G. (eds.). Petroleum geology of the Irish Sea and adjacent areas. Geological Society, London, Special Publications, 124, 387-397.

Bluck, B.J., 2002. The Midland Valley Terrane. In: Trewin, N.H. (ed). Geology of Scotland. Fourth Edition. Geological Society, London, 149-166. 
BoniJOLy, D. \& CASTAING, C. 1984. Fracturation et genèse des bassins stéphaniens du Massif Central français en regime compressif. Annales Société géologique du Nord, Lille, CIII, 187199.

British GeOlOGICAL SuRVey (BGS). 1994. East Midlands Hydrocarbon Prospectivity Report Confidential for DTI .

British Geological SuRVey (BGS). 1994. East Irish Sea. Special Sheet Edition. Solid Geology.1:250 000. (Edinburgh, Scotland: British Geological Survey)

BRodiE, J., \& White, N. 1994. Sedimentary basin inversion caused by igneous underplating: northwest European continental shelf. Geology, 22, 147-150.

Brown, D., Juhlin, C. \& PuchKov, V. 2002. (Eds.). Mountain Building in the Uralides: Pangea to the Present. Geophysical Monograph 132. (Washington DC: American Geophysical Union). 286pp.

Browne, M. A. E., DeAn, M. T., Hall, I. H. S., McAdam, A. D., MonRo, S. K., \& Chisholm, J. I. 1999. A lithostratigraphical framework for the Carboniferous rocks of the Midland Valley of Scotland. British Geological Survey, Research Report, RR/99/07.

Bushell, T. P. 1986. Reservoir geology of the Morecambe Field. In: BrooKs, J., Goff, J. C. AND VAN HoORN, B. (eds.). Habitat of Palaeozoic gas in NW Europe. Geological Society, London, Special Publications, 23, 189-208.

CALVer, M.A, 1968. The distribution of Westphalian marine faunas in northern England and adjoining areas. Proceedings of the Yorkshire Geological Society, 44, 479-496.

CHADWICK, R.A.1993. Aspects of basin inversion in southern Britain. Journal of the Geological Society of London, 150, 311-322.

CHADWICK, R. A. 1997. Fault analysis of the Cheshire Basin, NW England. In: MEAdows, N. S., TruebloOd, S., HARDMAN, M., \& CoWAN, G. (eds.). Petroleum geology of the Irish Sea and adjacent areas. Geological Society, London, Special Publications, 124, 297-313.

ChadWICK, R. A. \& Evans, D. J. 1995. The timing and direction of Permo-Triassic extension in southern Britain. In: Boldy, S. A. R., \& HARDMAN, R.F.P.(eds.). Permian and Triassic rifting in NW Europe. Geological Society, London, Special Publications, 91, 161-192.

CHADWICK, R. A., Evans, D. J. \& Holliday, D. W. 1993. The Maryport Fault: the post-Caledonian tectonic history of southern Britain in microcosm. Journal of the Geological Society of London, 150, 247-250.

Chadwick, R.A., Holliday, D.W., Holloway, S. \& HulberT, A.G. 1995. The NorthumberlandSolway basin and adjacent areas. Subsurface memoir of the British Geological Survey.

CHADWICK, R.A., JACKSON, D.I., BARnes, R.P., KimbelL, G.S., Johnson, H., ChiVERRELL, R.C., Thomas, G.S.P., Jones, N.S., Riley, N.J., Pickett, E.A., Young, B., HollidAy, D.W., Ball, D.F., MolyneuX, S.G., LONG, D,. Power, G.M., \& RoberTS, D.H. 2001. The geology of the Isle of Man and its offshore area. British Geological Survey Research Report, RR/01/06.

ChEW, D.M. \& StRachan, R.A. 2014. The Laurentian Caledonides of Scotland and Ireland. In: Corfu, F., Gasser, D.Q. \& Chew, D.M. (eds). New perspectives of the Caledonides of Scandinavia and Related Areas. Geological Society, London, Special Publications, 390, 45-91. 
Collinson, J. 1988. Controls on Namurian sedimentation in the Central Province basins of northern England. In: BesLy, B. \& Kelling, G. Sedimentation in a synorogenic basin complex: the Upper Carboniferous of northwest Europe. Blackie, Glasgow and London, 200-221.

COLTER, V. S. \& BARR, K.W. 1975. Recent developments in the geology of the Irish Sea and Cheshire basins. In: Woodland, A.W. (ed.). Petroleum and the Continental Shelf of North West Europe. Volume 1: Geology. Applied Science Publishers, London, 61-75.

COLTER, V. S. 1997. The East Irish Sea Basin - from caterpillar to butterfly, a thirty-year metamorphosis. In: Meadows, N.S., Trueblood, S.P., Hardman, M. \& Cowan, G. (eds.), Petroleum Geology of the Irish Sea and Adjacent Areas. Geological Society, London, Special Publications, 124, 1-10.

COPE, J. C. W. 1994. A latest Cretaceous hotspot and the southeasterly tilt of Britain. Journal of the Geological Society of London, 151, 905-908.

CoPE, J. C. W. 1997. The Mesozoic and Tertiary history of the Irish Sea. In: MEAdows, N S, Trueblood, S. P., HARdman, M., \& CowAN, G. (eds.). Petroleum geology of the Irish Sea and adjacent areas. Geological Society, London, Special Publications, 124, 47-59.

COPE, J.C.W., InGHAM, J.K. \& RAWSON, P.F. 1992. Atlas of palaeogeography and lithofacies. Geological Society, London, Memoir, 13.

CORCORAN, D. \& CLAYTON, G. 1999. Interpretation of vitrinite reflectance profiles in the Central Irish Sea area: implications for the timing of organic maturation. Journal of Petroleum Geology, 22, 261-286.

Corfield, S.M., GaWthorpe, R.L., Gage, M., Fraser, A.J. \& Besly, B.M. 1996. Inversion tectonics of the Variscan foreland of the British Isles. Journal of the Geological Society, London, 153, 17-32.

COWAN, G. \& BRADNEY, J. 1997. Regional diagenetic controls on reservoir properties in the Millom accumulation: implications for field development. In: MEADOws, N.S., TRUEBLOOD, S.P., Hardman, M. \& Cowan, G. (eds.), Petroleum Geology of the Irish Sea and Adjacent Areas. Geological Society, London, Special Publications, 124, 373-386.

Cowan, G., Burley, S., Hoey, N., Holloway, P., Bermingham, P., Beveridge, N., Hamborg, M., \& SYLTA, Ø., 1999. Oil and gas migration in the Sherwood Sandstone of the East Irish Sea Basin. In: FLEET, A. J. \& BOLDY, S. A. R. (eds.) Petroleum Geology of northwest Europe: Proceedings of the 5th Conference, Geological Society, London, 383-398.

COWARD, M. P. 1993. The effect of Late Caledonian and Variscan continental escape tectonics on basement structure, Paleozoic basin kinematics and subsequent Mesozoic basin development in NW Europe. In: PARKER, J. R. (ed.) Petroleum geology of Northwest Europe: Proceedings of the 4th Conference. The Geological Society, London, 1095-1108.

CowARD, M. P. 1995. Structural and tectonic setting of the Permo-Triassic basins of northwest Europe. In: Boldy, S. A. R., \& HARdMAn, R. F. P. (eds.). Permian and Triassic rifting in northwest Europe. Geological Society, London, Special Publications, 91, 7-40.

Craig, J., Gluyas, J., LAing, C. \& SChOFIELD, P. 2013. Hardstoft - Britain’s First Oil Field. Oil Industry History, 14, 97-116. 
De PaOla, N., Holdsworth, R. E., McCAffrey, K. J., \& BARChi, M. R. 2005. Partitioned transtension: an alternative to basin inversion models. Journal of Structural Geology, 27, 607625.

DeAn, M. T., Browne, M. A. E., WATERs, C. N., \& Powell, J. H. 2011. A lithostratigraphical framework for the Carboniferous successions of northern Great Britain (onshore) British Geological Survey Research Report, RR/10/07, 165pp.

DiCKSON, J. A. D, FORD, T. D., \& SWIFT, A. 1987. The stratigraphy of the Carboniferous rocks around Castletown, Isle of Man. Proceedings of the Yorkshire Geological Society, 46, 203229.

EASTWOOD, T., DiXON, E.E.L., HOLLINGWORTH, S.E. \& SMITH, B. 1931. The geology of the. Whitehaven and Workington district. Memoir of the Geological Survey of Great Britain, Sheet 28 (England \& Wales).

ENGLAND, R. W. \& SOPER, N.J. 1997. Lower crustal structure of the East Irish Sea from deep seismic reflection data. In: Meadows, N.S., Trueblood, S.P., Hardman, M. \& CowAN, G. (eds.), Petroleum Geology of the Irish Sea and Adjacent Areas. Geological Society, London, Special Publications, 124, 61-72.

FALCON, N. L. \& KENT, P. E. 1960. Geological results of petroleum exploration in Britain 19451957. Geological Society, London, Memoir 2.

FAURE, M. 1995. Late orogenic Carboniferous extensions in the Variscan French Massif Central. Tectonics, 14, 132-153.

Floodpage, J., NeWMAN, P. \& White, J. 2001. Hydrocarbon prospectivity in the Irish Sea area: insights from recent exploration of the Central Irish Sea, Peel and Solway basins. In: Shannon, P. M., Haughton, P. D. W. \& Corcoran, D. V. (eds.). The Petroleum Exploration of Ireland's Offshore Basins. Geological Society, London, Special Publications, 188, $107-134$.

FRASER A J. \& GAWTHORPE R L. 2003. An atlas of Carboniferous basin evolution in northern England. Geological Society, London, Memoir 28.

FRASER A J., NASH, D.F., STEELE, R.P. \& EBDON, C.C. 1990. A regional assessment of the intraCarboniferous play of northern England. In: BROOKS, J. (ed.). Classic Petroleum Provinces. Geological Society, London, Special Publications, 50, 417-440.

GÉlard, J. -P., CAstaing, C., Bonijoly, D., \& Grolier, J. 1986. Structure et dynamique de quelques bassins houlliers limniques du Massif Central. Memoire Société Géologique de France, 149,576-72.

GENT. C. M. A. 2016. Maturity modelling of well 110/07b-6. British Geological Survey Commissioned Report, CR/16/043.

GEOCHEM LABORATORIES LIMITED, 1988. Prepared for Kelt UK Ltd, London. Geochemical Evaluation and Correlation Study Morecambe Bay 110/7b-6 Well. (110_07b_6_rep_GEOL_CHEM_105249616.pdf released on CDA). 
GiBBONS, W. 1987. The Menai Strait fault system: an early Caledonian terrane boundary in North Wales. Geology 15, 744-747.

Giles, M.R., \& IndRelid, S.L. 1998. Divining burial and thermal histories from indicator data: application and limitations. In: VAN Den HaUte, P. \& De Corte, F. (eds.) Advances in Fission Track Geochronology. Kluwer Academic Publishers, Dordrecht, 115-150.

GREEN, P. F., DUDDY, I. R. \& BRAY, R. J. 1997. Variation in thermal history styles around the Irish Sea and adjacent areas: implications for hydrocarbon occurrence and tectonic evolution. In: Meadows. N., Trueblood, S., Hardman, M. \& CowAN, G. (eds.). Petroleum Geology of the Irish Sea and Adjacent Areas. Geological Society, London, Special Publications, 124, 7393.

Grolier, J. 1971. Le tectonique du socle hercynien dans le Massif Central. In: Jung, J. (Ed.). Symposium.: Géologie, géomorphologie et structure profonde du Massif Central français. (Clermont-Ferrand: Plein Air Service), 215-260.

Haig, D.B., Pickering, S.C. \& Probert, R. 1997. The Lennox oil and gas Field. In: MeAdows, N.S., Trueblood, S.P., Hardman, M. \& CowAn, G. (eds.). Petroleum Geology of the Irish Sea and Adjacent Areas. Geological Society, London, Special Publications, 124, 417-436.

Hallett, D., Durant, G.P. \& FARROW, G.E. 1985. Oil exploration and production in Scotland. Scottish Journal of Geology, 21, 547-570.

HANNIS, S. 2016. Reservoir evaluation of 8 wells in the Palaeozoic of the Irish Sea: Petrophysical interpretations of clay volume, porosity and permeability estimations. British Geological Survey Commissioned Report, CR/16/042.

HARDMAN, M., BuchanAn, J., HERrington, P. \& CARR, A. 1993. Geochemical modelling of the East Irish Sea Basin: its influence on predicting hydrocarbon type and quality. In: PARKER, J. R. (ed.). Petroleum Geology of Northwest Europe: Proceedings of the 4th Conference, Geological Society, London, 809-821.

HiLlieR, R.D. \& Williams, B.P.J. 2006. The alluvial Old Red Sandstone: fluvial basins. Chapter 8 Geological Society, London, 809-821.In: BRENCHLEY, P.J. \& RAWSON, P.F. (eds.) 2006. The Geology of England and Wales. Second Edition. Geological Society, London, 103-129.

JACKSON, D.I., JACKSON, A.A., Evans, D., WingFiElD, R.T.R., BARNES, R.P. \& ARTHUR, M.J. 1995. United Kingdom offshore regional report: the geology of the Irish Sea. HMSO, London.

JACKSON, D.I. \& JOHNSON, H. 1996. Lithostratigraphic nomenclature of the Triassic, Permian and Carboniferous of the UK offshore East Irish Sea Basin. (Nottingham: British Geological Survey).

JACKSON, D.I., JOHNSON, H. \& SMITH, N.J.P. 1997. Stratigraphical relationships and a revised lithostratigraphical nomenclature for the Carboniferous, Permian and Triassic rocks of the offshore East Irish Sea Basin. In: Meadows, N.S., Trueblood, S.P., Hardman, M. \& CowAN, G. (eds.), Petroleum Geology of the Irish Sea and Adjacent Areas. Geological Society, London, Special Publications, 124, 11-32.

JACKSON, D.I., JONES, N.S., \& WATERS, C.N. 2011. Chapter 16: Irish Sea (including Kish Bank). In: WATERS, C.N., SOMERVILle, I.D., JONES, N.S., CleAl, C.J., COLlinson, J.D., WATERS, R.A., Besly, B.M., DEAN, M.T., STEPHENSON, M.H., DAVIES, J.R., FreshneY, E.C., 
Jackson, D.I., Mitchell, W.I., Powell, J.H., Barclay, W.J., Browne, M.A.E., LEVERIDGE, B.E., LONG, S.L., \& MCLEAN, D. (eds). A Revised Correlation of Carboniferous Rocks in the British Isles. Geological Society, London, Special Reports, 26, 110-116.

JACKSON, D I, \& Mulholland, P. 1993. Tectonic and stratigraphical aspects of the East Irish Sea Basin and adjacent areas: contrasts in their post-Carboniferous structural styles. In: PARKER, J $\mathrm{R}$ (ed.). Petroleum geology of northwest Europe: Proceedings of the 4th Conference. Geological Society, London, 791-808.

JACKSON, D.I., Mulholland, P., JONES, S.M. \& WARRINGTON, G. 1987. The geological framework of the East Irish Sea Basin. In: Brooks J. \& GlenNie, K. (ed.) Petroleum Geology of North West Europe, 191-203. Graham and Trotman, London.

Jenner, J.K. 1981. The structure and stratigraphy of the Kish Bank Basin. In: ILLIng, L.V. \& Hobson, G.D. (eds). Petroleum Geology of the Continental Shelf of North West Europe. Heyden, London.

Jones, N. S., HollidAy, D. W. \& McKervey, J. A. 2011. Warwickshire Group (Pennsylvanian) redbeds of the Canonbie Coalfield, England-Scotland border, and their regional palaeogeographical implications. Geological Magazine, 148, 50-77

KENT, P. E. 1978. Subsidence and uplift in East Yorkshire and Lincolnshire: a double inversion. Proceedings of the Yorkshire Geological Society, 42, 505-524.

KeNT, P. E. 1985. UK onshore oil exploration, 1930-1964. Marine and Petroleum Geology, 2, 56-64.

KIMBELL, G. S. \& QUIRK, D. G. 1999. Crustal magnetic structure of the Irish Sea region: evidence for a major basement boundary beneath the Isle of Man. 227-238. In: WoODCOCK, N. H., QUIRK, D. G., FITCHES, W. R. \& BARNES, R. P. (eds.). In sight of the suture: the geology of the Isle of Man in its Iapetus Ocean context. Geological Society, London, Special Publications, 160, 227-238.

Kirby, G. A., Baily, H. E., Chadwick, R. A., Evans, D. J., Holliday, D. W., Holloway, S., Hulbert, A. G., Pharaoh, T. C., Smith, N. J. P., Aitkenhead, N. \& Birch, B. 2000. The structure and evolution of the Craven Basin and adjacent areas. Subsurface Memoir of the British Geological Survey. (Keyworth, Nottingham: British Geological Survey.) 130pp.

KIRTON, S. R. \& DONATO, J. A. 1985. Some buried Tertiary dykes of Britain and surrounding waters deduced by magnetic modelling and seismic reflection methods. Journal of the Geological Society of London, 142, 1047-1057.

KNIPE, R. J., CowAn, G., \& BALENDRAN, V. S. 1993. The tectonic history of the East Irish Sea Basin with reference to the Morecambe Fields. In: PARKER, J. R. (ed.). Petroleum geology of northwest Europe: Proceedings of the 4th Conference. Geological Society, London, 857-866.

KupecZ, J.A., AREstad, J.F. \& BlotT, J.E. 1996. Integrated study of Mississippian Lodgepole Waulsortian Mounds, Williston Basin, USA. Society of Exploration Geophysicists, SEG1996-0401.

LEedER, M. R. 1982. Upper Palaeozoic basins of the British Isles - Caledonide inheritance versus Hercynian plate margin processes. Journal of the Geological Society of London, 139, 479-491.

Leslie, A.G., Millward, D., Pharaoh, T., Monaghan, A.A., Aresenikos, S., Quinn, M. 2015. Tectonic synthesis and contextual setting for the Central North Sea and adjacent onshore 
areas, 21CXRM Palaeozoic Project. British Geological Survey Commissioned Report, CR/15/125. 18pp

MADDOX, S.J., BLOW, R.A. \& O’BRIEN, S.R. 1997. The Geology and hydrocarbon prospectivity of the North Channel Basin. In: Meadows, N.S., TruebloOd, S.P., Hardman, M. \& CowAN, G. (eds.), Petroleum Geology of the Irish Sea and Adjacent Areas. Geological Society, London, Special Publications, 124, 95-111.

Meadows, N.S., TruebloOd, S.P., Hardman, M. \& Cowan, G. 1997. (eds.), Petroleum Geology of the Irish Sea and Adjacent Areas. Geological Society, London, Special Publications, 124, 447pp.

MitcheLL, W. I. (ed.). 2004. The Geology of Northern Ireland-Our Natural Foundation. Geological Survey of Northern Ireland, Belfast.

Monaghan, A. A. \& Pringle, M. S. 2014. ${ }^{40} \mathrm{Ar} /{ }^{39} \mathrm{Ar}$ geochronology of Carboniferous-Permian volcanism in the Midland Valley, Scotland. In: Wilson, M., NEumann, E.-R., Davies, G.R., Timmermann, M.J., Heeremans, M. \& Larsen, B.T. (eds.). Permo-Carboniferous Magmatism and Rifting in Europe. Geological Society, London, Special Publications, 223, 219-241.

Monaghan, A. A. 2014. The Carboniferous shales of the Midland Valley of Scotland: geology and resource estimation. British Geological Survey for Department of Energy and Climate Change, London, UK.

NAdin, P A, \& KUZNiR, N J. 1995. Palaeocene uplift and Eocene subsidence in the northern North Sea Basin from 2D forward and reverse stratigraphic modelling. Journal of the Geological Society of London, 152, 833-848.

NewMan, P. J. 1999. The geology and hydrocarbon potential of the Peel and Solway Basins, East Irish Sea. Journal of Petroleum Geology, 22, 305-324.

Oliver, G.J.H., StONE, P. \& Bluck, B.J. 2002. The Ballantrae Complex and the Southern Uplands Terrane. In: TrEwIN, N.H. (ed). Geology of Scotland. Fourth Edition. Geological Society, London, 149-166.

PARNELL, 1997. Fluid migration history in the North Irish Sea-North Channel region. In: MEAdows, N.S., Trueblood, S.P., Hardman, M. \& CowAn, G. (eds.), Petroleum Geology of the Irish Sea and Adjacent Areas. Geological Society, London, Special Publications, 124, 213-228.

PEACE, G.R. \& BeSLY, B.M. 1997. End-Carboniferous fold-thrust structures, Oxfordshire, UK: implications for the structural evolution of the late Variscan foreland of south-central England. Journal of the Geological Society of London, 154, 225-237.

Penn, I., Holliday, D. W., Kirby, G. A., Kubala, M., Sobey, R. A., Mitchell, W. I., Harrison, R. K. \& BecKinsale, R. D. 1983. The Larne No. 2 Borehole: discovery of a new Permian volcanic centre. Scottish Journal of Geology, 19, 333-34

Pharaoh, T.C., Kirk, K., Quinn, M., SANKey, M. \& Monaghan, A.A. 2016a. Seismic Interpretation and generation of depth surfaces for late Palaeozoic strata in the Irish Sea Region. British Geological Survey Commissioned Report, CR/16/041. 65pp. 
Pharaoh, T C, Winchester, J A, Verniers, J, Lassen, A, \& Seghedi, A. 2006. The western accretionary margin of the east European craton: an overview. In: GEE, D.G.and STEPHENSON, R.A. (Eds). European Lithosphere Dynamics. Geological Society, London, Memoir 32, 291-311.

Pharaoh, T. C., Vincent, C. J., Bentham, M. S., Hulbert, A. G., Waters, C. N., \& Smith, N. J. 2011. Structure and evolution of the East Midlands region of the Pennine Basin. Subsurface memoir of the British Geological Survey. 144pp.

PharaOH, T.C., Smith, N.J.P., KIRK, K.,KImbelL, G.S., Gent, C., Quinn, M., \& MonaGhan, A.A. 2016b. Palaeozoic Petroleum Systems of the Irish Sea. British Geological Survey Commissioned Report, CR/16/045. 135pp.

Pharaoh, TC., Dusar, M, Geluk, M., Kockel, F., KrawczyK, C., Krzywiec, P., ScheckWenderoth, M., Thybo, H., Vejbaek, O. \&VAn Wees, J-D.. 2010. In: Doornenbal, J. H.\& Stevenson, A. G.(eds.). Chapter 3 Tectonic Evolution Petroleum Geological Atlas of the Southern Permian Basin Area. EAGE Publications b.v., Houten, 25-58.

Pletsch, T., Appel, J., Botor, D., Clayton, C.J., Duin, E J T., Faber, E., Gorecki, W., Kombrink, H., Kosakowski, P., Kuper, G.,Kus, J., LutZ, R., Mathiesen, A., OstertaGHenning, C., PAPIERneK, B. \& VAn Bergen, F. 2010. Chapter 12 Petroleum generation and migration. In: Doornenbal, J. C. \& Stevenson, A. G. (eds.). Petroleum Geological Atlas of the Southern Permian Basin Area. EAGE Publications b.v., Houten, 225-253.

PROVIDENCE, 2013. Frontier exploration opportunities Rathlin Trough, offshore Northern Ireland. PROSPEX, Dec 2013.

PuchKov, V. N. 1997. Structure and geodynamics of the Uralian orogeny. In: BuRG, J. -P., \& ForD, M. (eds.). Orogeny Through Time. Geological Society, London, Special Publications, 121, 201-236.

QUINN, M. F. 2008. A geological interpretation of the Larne and Portpatrick sub-basins, offshore Northern Ireland, with an evaluation of an area proposed for gas storage in salt caverns. British Geological Survey Commissioned Report, CR/08/064. 77pp. Commercial-inConfidence.

QUiRK, D. G., \& KiMBELL, G. S. 1997. Structural evolution of the Isle of Man and central part of the Irish Sea. In: Meadows, N. S., Trueblood, S., Hardman, M., \& Cowan, G. (eds.). Petroleum Geology of the Irish Sea and adjacent areas. Geological Society, London, Special Publications, 124. 135-159.

Quirk, D. G., RoY, S., KNOTT, I., REDFERN, J. \& HiLl, L., 1999Petroleum geology and future hydrocarbon potential of the Irish Sea. Journal of Petroleum Geology, 22, 243-260.

RACEY, A. 1999. Palynolgical and geochemical analysis of Carboniferous borehole and outcrop samples from the Isle of Man. Journal of Petroleum Geology, 22, 349-362.

RamsвотtOM, W. H. C. 1969. Reef distribution in the British Lower Carboniferous. Nature, 222, 765-766.

RAMSBOtTOM, W. H. C., CALVER, M.A., EAGAR, R.M.C., HODSON, F., HOLLIDAY, D.W., STUBBLEFIELD, C.J., \& WILSON, R.B. 1978. A Correlation of Silesian Rocks in the British Isles. Geological Society, London, Special Reports 10. 
ReAD, W.A., Browne, M.A., StePhenson, D. \& Upton, B.G.J. Carboniferous. Chapter 9 In: TrEWIN, N.H. (ed). Geology of Scotland. Fourth Edition. Geological Society, London, 149166.

REAY, D.M. 2004. Oil and Gas. In: MitcheLL, W.I. (ED.). The Geology of Northern IrelandOur Natural Foundation. Geological Survey of Northern Ireland, Belfast. ISBN 085272-454-3. 273-290

REAY, D.M. 2012. Geology and Gas in Northern Ireland. Future of natural gas seminar. Dundalk, Ireland. March 2012.

Scheck-Wenderoth, M., Krzywiec, P., ZÜhlke, R., Maystrenko, Y. \& Froitzheim. 2008. Permian to Cretaceous tectonics. In: McCann, T. (ed.). The Geology of Central Europe. Volume 2: Mesozoic and Cenozoic. Geological Society, London, 999-1030.

Shelton, R. 1997. Tectonic evolution of the Larne Basin. In: MeAdOWS, N.S., TrueblOOD, S.P., Hardman, M. \& Cowan, G. (eds.), Petroleum Geology of the Irish Sea and Adjacent Areas. Geological Society, London, Special Publications, 124, 113-134.

SMITH, M., RoBERTSON, S. \& RolLIN, K.E. 1999. Rift basin architecture and stratigraphical implications for basement-cover relationships in the Neoproterozoic Grampian Group of the Scottish Caledonides. Journal of the Geological Society, London, 156, 1163-1173.

SMITH, N. J. P. (Compiler) 1985. Map 1: Pre-Permian Geology of the United Kingdom (South). 1:1,000,000 scale. British Geological Survey, Nottingham.

SMith, N. J. P. 1999. Gas seepage: shrines, curiosities and hazards. Earthwise, 14, 9. British Geological Survey, Nottingham.

SMITH, N. J. P. (in prep.). The UK's unconformity maps used for assessing basin configuration and in support of hydrocarbon prospectivity. Conference at Geological Society, May 26-27, 2016.

Smith, N. J. P., ChadWick, R. A., WARrington, G., KirBY, G. A. \& Jones, D. 1995. The hydrocarbon prospectivity of the Cheshire Basin and surrounding areas. BGS Technical Report WA/94/95C. 37pp.

Smith, N. J. P., KirBy, G. A. \& PhARAOH, T. C. 2005. Structure and evolution of the south-west Pennine Basin and adjacent area. Subsurface Memoir of the British Geological Survey. (Keyworth, Nottingham: British Geological Survey.)

StUART, I.A. 1993. The geology of the North Morecambe Gas Field, East Irish Sea Basin. Jn: PARKer, J. R. (ed.). Petroleum Geology of Northwest Europe: Proceedings of the 4th Conference. Geological Society, London, 883-895.

StUART, I. A. \& CowAn, G. 1991. The south Morecambe Field, blocks 110/2a, 110/3a, 110/8a, UK East Irish Sea. In: AввотTS, I. L. (ed.). United Kingdom Oil and Gas Fields, 25 Years Commemorative Volume. Geological Society, London, Memoir 14, 527-541.

SuESS, E. 1904. The Face of the Earth. Clrendon Press, Oxford.

Thompson, J. \& Meadows, N.S. 1997. In: Meadows, N.S., Trueblood, S.P., HaRdMan, M. \& CowAN, G. (eds.), Petroleum Geology of the Irish Sea and Adjacent Areas. Geological Society, London, Special Publications, 124, 237-252. 
Timmerman, M.J. 2004. Timing, geodynamic setting and character of Permo-Carboniferous magmatism in the foreland of the Variscan Orogen, NW Europe. In: WiLSON, M., NEumanN, E.-R., Davies, G.R., Timmermann, M.J., HeEremans, M. \& LARSen, B.T. (eds.). PermoCarboniferous Magmatism and Rifting in Europe. Geological Society, London, Special Publications, 223, 219-241.

Trewin, N.H. \& Thirlwall, M.F. 2002. Old Red Sandstone. Chapter 8. In: Trewin, N.H. (ed). Geology of Scotland. Fourth Edition. Geological Society, London, 149-166.

Trotter, F. M. 1954. Reddened beds in the Coal Measures of Lancashire. Bulletin of the Geological Survey, 5, 61-80.

UNDERHILL, J. R. 2003. The tectonic and stratigraphic framework of the United Kingdom's oil and gas fields. In GluYAS, J. G. \& HiCHENS, H. M. (eds.). United Kingdom Oil and Gas Fields, Commemorative Millennium Volume. Geological Society, London, Memoir 20, 17-59.

Underhill, J. R., Monaghan, A. A. \& Browne, M. A. E. 2008. Controls on structural styles, basin development and petroleum prospectivity in the Midland Valley of Scotland. Journal of Marine and Petroleum Geology, 25, 1000-1022

VAn Hoorn, B. 1987. Structural evolution, timing and tectonic style of the Sole Pit inversion. Tectonophysics, 137, 239-284.

VAne, C. H., Uguna, C., Kim, A. W. \& Monaghan, A. A., 2016. Organic Geochemistry of Palaeozoic Source Rocks of the Irish Sea, UK. British Geological Survey. Commissioned Report. CR/16/044.

WAKEFIELD, O., WATERS, C.N., \& SMITH, N.J.P. 2016. Carboniferous stratigraphical correlation and interpretation in the Irish Sea. British Geological Survey Commissioned Report, CR/16/040. 81pp.

WALKDEN, G. M. \& DAVIES, J. R. 1983. Polyphase erosion of subaerial omission surfaces in the late Dinantian of Anglesey. Sedimentology, 30, 861-878.

WARD, J. 1997. Early Dinantian evaporites of the Easton-1 well, Solway basin, onshore, Cumbria, England. In: Meadows, N.S., TruebloOd, S.P., Hardman, M. \& Cowan, G. (eds.), Petroleum Geology of the Irish Sea and adjacent areas. Geological Society, London, Special Publications, 124, 277-296.

WARRINGTON, G. 1997. The Penarth Group-Lias Group succession (Late Triassic-Early Jurassic) in the East Irish Sea Basin and neighbouring areas: a stratigraphical review. In: MEADOws, N.S., Trueblood, S.P., Hardman, M. \& CowAn, G. (eds.), Petroleum Geology of the Irish Sea and Adjacent Areas. Geological Society, London, Special Publications, 124, 33-46.

WATERS, C. N. \& CondON, D. J. 2012. Nature and timing of Late Mississippian to MidPennsylvanian glacio-eustatic sea-level changes of the Pennine Basin, UK. Journal of the Geological Society, 169, 37-51.

Waters, C. N., Somerville, I. D., Jones, N. S., Cleal, C. J., Collinson, J. D., WATERS, R. A., Besly, B. M., Dean, M. T., Stephenson, M. H., Davies, J. R., Freshney, E. C., JaCKSON, D. I., MitChell, W. I., POWEll, J. H., BARClay, W. J., Browne, M. A. E., LEVERIDGE, B. 
E., LONG, S. L. \& MCCLEAN, D. (EDS.). 2011. A revised correlation of Carboniferous rocks in the British Isles. Geological Society, London, Special Reports, 26.

WHITE, R. S. 1988. A hot-spot model for early Cenozoic volcanism in the North Atlantic. In: PARSON, L. M., \& MORTON, A. C. (eds.). Early Cenozoic volcanism and the opening of the North Atlantic. Geological Society, London, Special Publications, 39. 3-13.

WHITTAKER, A., 1985 Atlas of Onshore Sedimentary basins. Blackie/British Geological Survey

WOOD, I. 2014. UKCS Maximising Recovery Review: Final Report. HMSO; London.

Woodcock, N.H. \& Soper, N.J. 2006. The Acadian Orogeny: The mid-Devonian phase of deformation that formed slate belts in England and Wales. .In: BRENCHLEY, P.J. \& RAwSON, P.F. (eds) 2006. The Geology of England and Wales. Second Edition. Geological Society, London, 103-129.

WOODWARD, K. \& CURTIS, C. D. 1987. Predictive modelling of the distribution of production constraining illites - Morecambe Gas Field, Irish Sea, Offshore UK. In: BROOKS, J. \& GLENNIE, K. (eds.). Petroleum Geology of North West Europe. Graham \& Trotman, London, 205-215.

Yaliz, A. M. 1997. The Douglas Oil Field. In: Meadows, N. S., Trueblood, S. P., Hardman, M. \& CowAN, G. (eds.), Petroleum Geology of the Irish Sea and Adjacent Areas. Geological Society, London, Special Publications, 124, 399-416.

YALIZ, A. \& TAYLOR, P. 2003. The Hamilton and Hamilton North Gas Fields, Block 110/13a, East Irish Sea. In: GluYAS, J. G. \& Hitchens, H. M. (eds.) United Kingdom Oil and Gas Fields, Commemorative Millennium Volume. Geological Society, London, Memoir 20, 77-86.

ZIEGLER, P. A. 1990. Geological Atlas of Western and Central Europe. Second Edition. Elsevier for Shell Internationale Petroleum Maatschappij B. V., Amsterdam.

Zonenshain, L.P., Korinevsky, V. G., Kazmin, V. G. , Pechersky, D.M., Khain, V. V.,\& MATEVEENKOV, V. V. 1984. Plate tectonic model of the south Urals development. Tectonophysics, 109, 95-135. 


\section{Figure captions}

Fig. 1. Key data evaluated during the study (2D seismic, black; 3D seismic outline, grey; wells proving Carboniferous strata, black dot; wells used in the petrophysical study, black square).

Fig. 2. Key Mississippian structural elements of the greater Irish Sea province. Incorporates information from Maddox et al. (1997), Parnell (1997) and Shelton (1997). Location of PermoTriassic basinal features (for reference purposes) in red: BB, Berw Basin; CP, Conwy Platform; DP, Deemster Platform; EB, Eubonia Basin; ED, East Deemster Basin; GB, Gogarth Basin; GC, Godred Croven Basin; KB, Keys Basin; LB, Lagman Basin; MF, Manx-Furness Ridge; NC, North Channel Basin; OP, Ogham Platform; PB, Peel Basin; Q109S, Quadrant 109 Syncline; SB, Solway Basin; TB, Tynwald Basin; WD, West Deemster Basin..The basin names used are those of the Permo-Triassic EISB and contemporary basins, following Jackson \& Mulholland (1993) and BGS (1994), rather than those of the Carboniferous elements newly named in this paper. Location of sections depicted in later figures: red line, seismic profiles (Fig. 3); green line, synoptic diagrams (Figs. 4, 5); black line, well transects (Fig. 9).

Fig. 3. Seismic reflection data. Locations are shown in Figs. 2 and 6. N.B. vertical scales in s TWTT.

a. Migrated seismic reflection line NW-SE across Quadrant 109: JEBCO JS-MANX-138. Includes content supplied by IHS Global Limited. Copyright @ IHS Global Limited (2016). All rights reserved. Note the considerable thickness of Carboniferous strata in the Eubonia Tilt-block, here exceeding 2.5 s TWTT; brighter reflectivity towards top of tilt-block below Intra-Visean unconformity possibly reflecting reefal development; and in the south, a northward-vergent anticline-thrust inversion couple, defining the northern edge of the Môn-Deemster Basin. The presence of Warwickshire Group strata is inferred from seismostratigraphic principles and has not yet been confirmed by drilling.

b. Arbitrary NNW-SSE line through the migrated 3D TerraCube ${ }^{\circledR}$ dataset, supplied courtesy of CGG GeoSpec. Note the presence of a series of inversion anticlines (Môn-Deemster Foldbelt) in the Carboniferous sequence, associated with thrusts (fault-plane reflections) which penetrate into the Caledonian basement. A less steeply dipping detachment is present at depth. The Bowland Shale Formation is inferred to occupy a rather transparent zone, sandwiched between more reflective Carboniferous Limestone Group (below) and Millstone Grit Group (above). The mildly deviated well 110/07b-6 proved $450 \mathrm{~m}$ of Bowland Shale Formation before terminating in strata of Pendleian age (unbottomed). Westphalian strata have been almost completely eroded following strong inversion during the earliest Variscan phase. Inversion anticlines of this generation were reactivated 'posthumously' by further compression during the Alpine Orogeny in Miocene time, producing more gentle anticlines in the Permo-Triassic cover, including the traps in the Ormskirk Sandstone Formation (Top SSG pick) hosting the Conwy, Douglas and other fields.

Fig. 4. Synoptic diagrams ('cartoons') to illustrate principal elements of the hydrocarbon system of the greater Irish Sea province. Locations are shown in Figs. 2 and 6. N.B. vertical scales in s TWTT. The basin names used are principally those of the Permo-Triassic EISB and contemporary basins, rather than those of the Carboniferous elements newly named here:

a. Principal elements of the hydrocarbon system in the Eubonia Basin and Q109 Arch. Transect is parallel to Fig. 3a and father east, into the Eubonia Basin.

b. Principal elements of the EISB from the Lagman Fault (north) to the Welsh margin (south). The northern part crosses from the Ogham Platform, to the Lagman and Keys basins, where Westphalian strata are almost completely removed, the West Deemster Basin and Deemster Platform.Note 
thickening of the Bowland Shale Formation beneath Deemster Platform, associated with the offshore extension of the Bowland Basin. The southern part crosses the Môn-Deemster Foldbelt and is virtually colinear with Fig. 3b.

c. Principal elements of the hydrocarbon system in the Peel Basin. Note that fault displacements appear to be largely of post-Permian age, indicating little if any syn-depositional thickening across the Visean carbonate platform. Post-Visean strata were only preserved on the Manx margin.

Fig. 5. Synoptic diagrams ('cartoons') to illustrate principal elements of the hydrocarbon system of the greater Irish Sea province. Locations are shown in Figs. 2 and 6. N.B. vertical scales in s TWTT. The basin names used are principally those of the Permo-Triassic EISB and contemporary basins, rather than those of the Carboniferous elements newly named here:

a. Principal elements of the hydrocarbon system in the eastern part of the Solway Firth Basin. Note the preservation of late Westphalian Warwickshire Group (Whitehaven Sandstone Formation) in the Cumbrian Coalfield adjacent to the Maryport Fault, and the axis of Alpine inversion significantly offset from the Variscan one. The Visean strata here are Border Group and Yoredale facies, with uncertain source potential.

b. Principal elements of the hydrocarbon system in the northern part of the EISB. The WSW-ENE transect crosses Variscan second phase inversion structures obliquely in the Ogham Inlier, western Keys Basin and the Cumbrian margin.

c. Principal elements of the hydrocarbon system in the southern part of the EISB. The W-E transect is located parallel to the southern edge of the Môn-Deemster Foldbelt, crossing some of the Variscan first inversion phase structures obliquely. N-S trending inversion structures of the second Variscan phase at the margins of the East Deemster Basin and on the Formby Platform are crossed obliquely. Note the excision of Westphalian strata on these inversion systems. Modified from Yaliz (1997; Figure 4).

Fig.6. Pre-Permian subcrop map showing key Variscan inversion structures (after Pharaoh et al. 2016b). Variscan inversion structures in Ogham Platform after Quirk \& Kimbell (1997). Abbreviated structure names: DP, Deemster Platform; EDB, East Deemster Western Boundary Fault; FPF, Formby Point Fault; OP, Ogham Platform; RE, Ribble Estuary Inlier. Location of sections depicted in other figures: red line, seismic profiles (Fig. 3); green line, synoptic diagrams (Figs. 4, 5); black line, well transects (Fig. 9).Hydrocarbon fields from OGA website:

http://data.ogauthority.opendata.arcgis.com/datasets/

Fig.7. Petroleum system elements in a north-south transect across the central part of the region

Fig.8. Pendleian palaeogeography showing the Bowland Shale source rock distribution and lateral varation with Millstone Grit facies (from Wakefield et al. 2016).

Fig. 9. Well transects (from Wakefield et al. 2016). Locations are shown in Figs. 2 and 6. a. N-S transect across the EISB from the Lagman Basin to Rhuddlan, onshore North Wales. Note the truncation of the Warwickshire Group north of Point of Ayr and condensation of the underlying Westphalian strata, southward onto the Cambrian margin. Also note the variation in the thickness of the Appleby Group. b. W-E transect across the centre of the EISB from 109/5-1 in the Eubonia Basin to Roosecote, onshore north Cumbria. 
Fig.10. Seismic structure map in depth (metres sub-sea level) for the Intra-Namurian pick, equated with the base of the Millstone Grit Group. Location of abbreviated Permo-Triassic basinal features (for reference purposes), refer to key to Figure 2.

Fig.11. A summary of the available geochemical data for Bowland Shale Formation lithologies in well 110/07b-6 and 110/02b-10. Data sourced from released legacy reports. Note that no Oxygen Index data are available for well 110/07b-6, so the data in the Pseudo-Van Krevelen Plot (Figure 11b) is from well 110/02b-10 (Millstone Grit and Pennine Coal Measures groups).

Fig.12. Modelled burial history for 110/07b- 6 showing that the Bowland Shale source rock entered the main gas generation window in the late Cretaceous-early Cenozoic. The well terminates within the Bowland Shale Formation.

Fig.13. Cross plot of core porosity and permeability for East Irish Sea Basin samples. For key to abbreviations see Table 1, except for PLC, Pennine Lower Coal Measures and PMCM, Pennine Middle Coal Measures.

Table 1. Synthesis of petrophysical results by formation (from Hannis, 2016). NTG = Net reservoir thickness to gross formation thickness. Porosity and net-to-gross are expressed as a fraction. Minimum porosity in the log-derived porosity range is 0.05 , the net reservoir porosity cut-off value. Permeability figures are in $\mathrm{mD}$. Core porosity and permeability data are synthesised from legacy reports. 


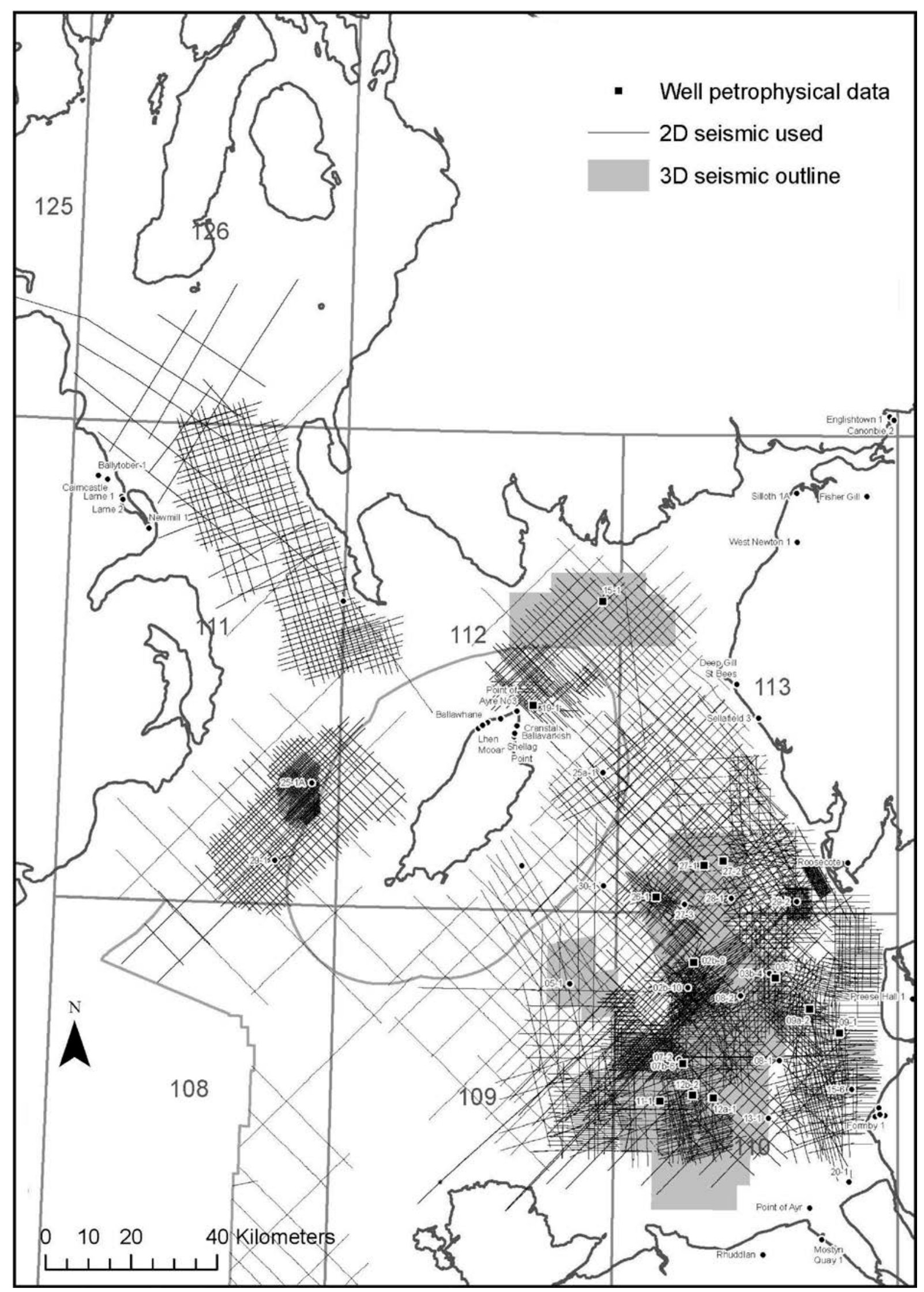

Fig. 1 


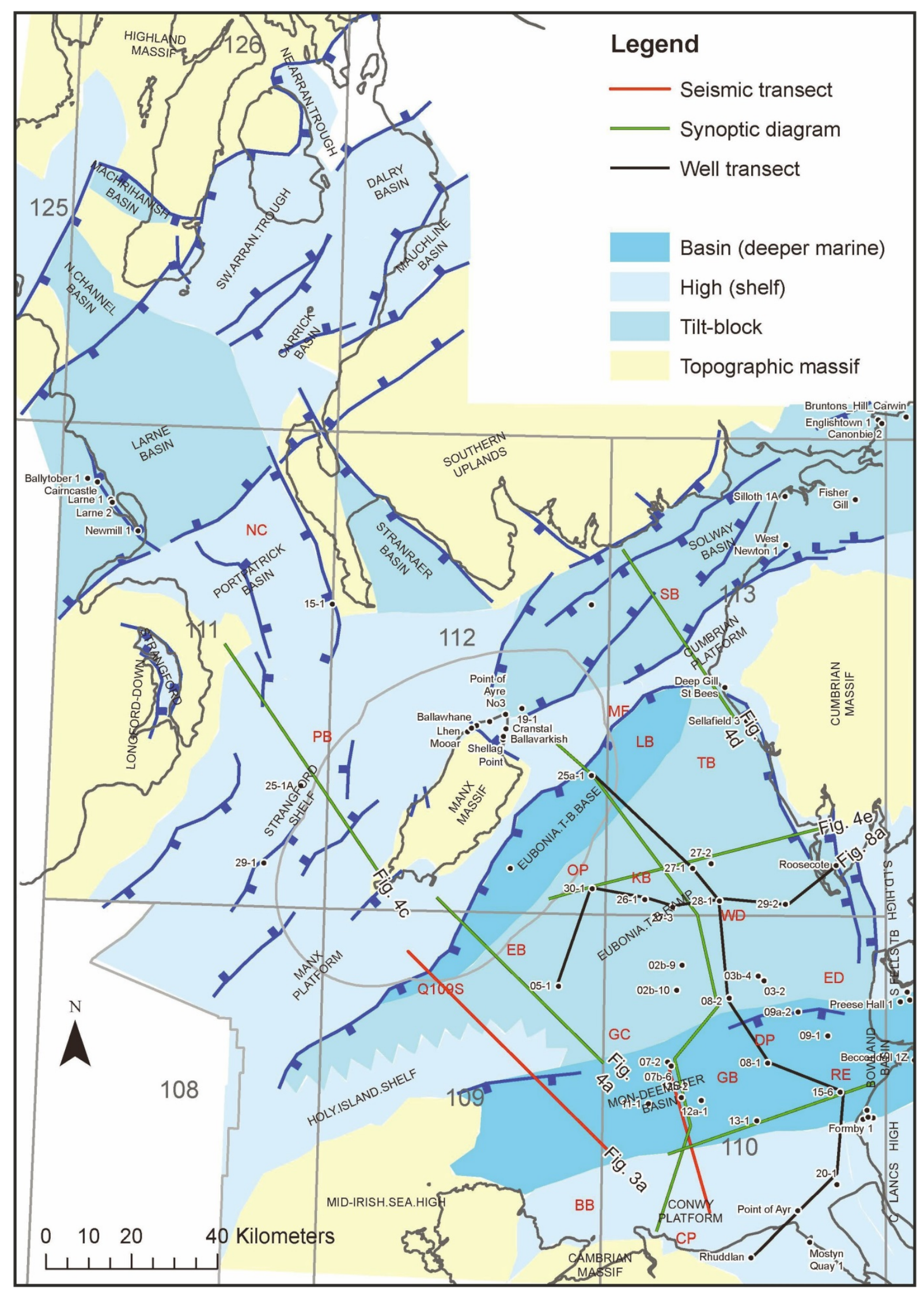

Fig. 2 


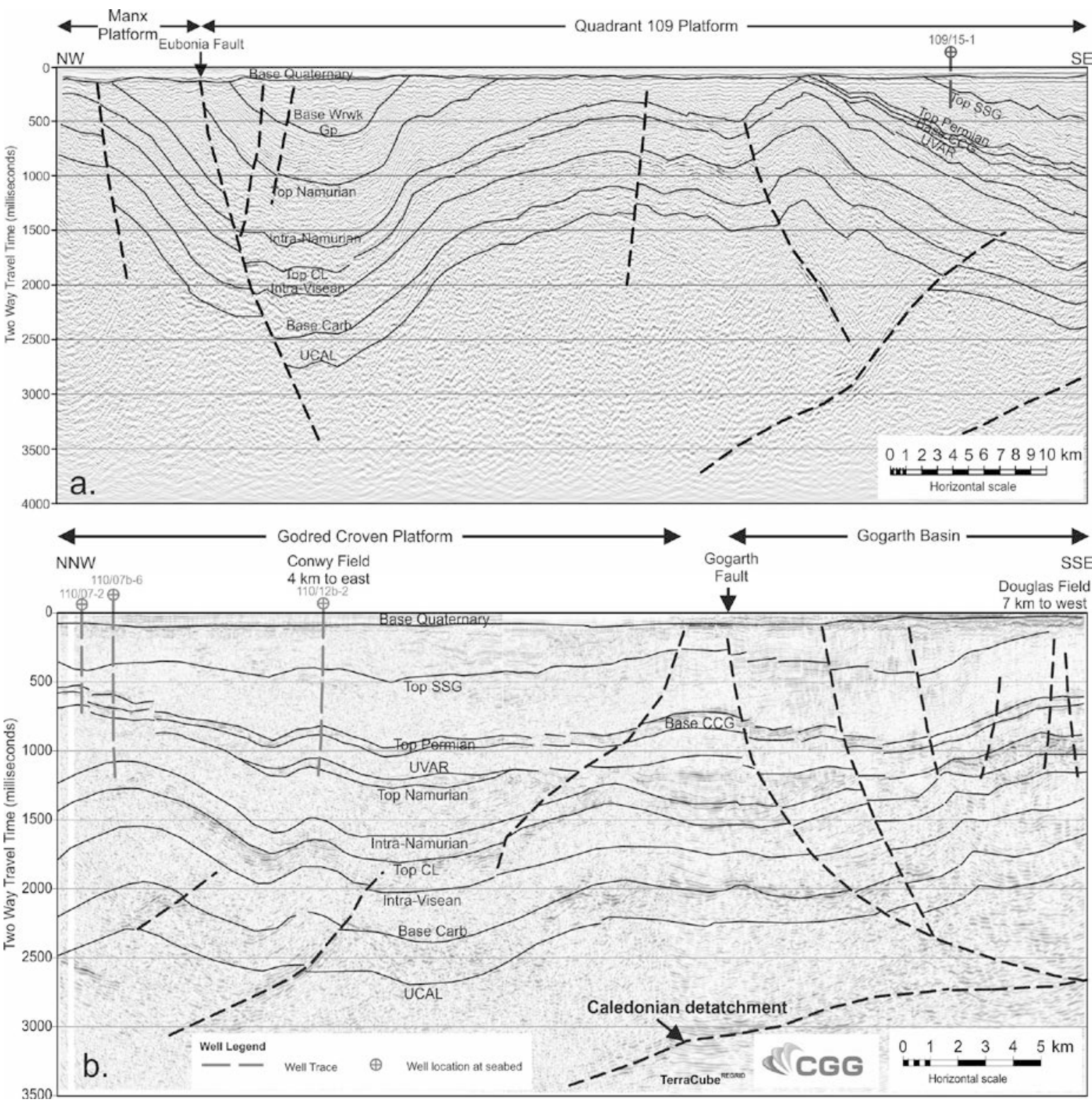

Fig. 3 a, b 

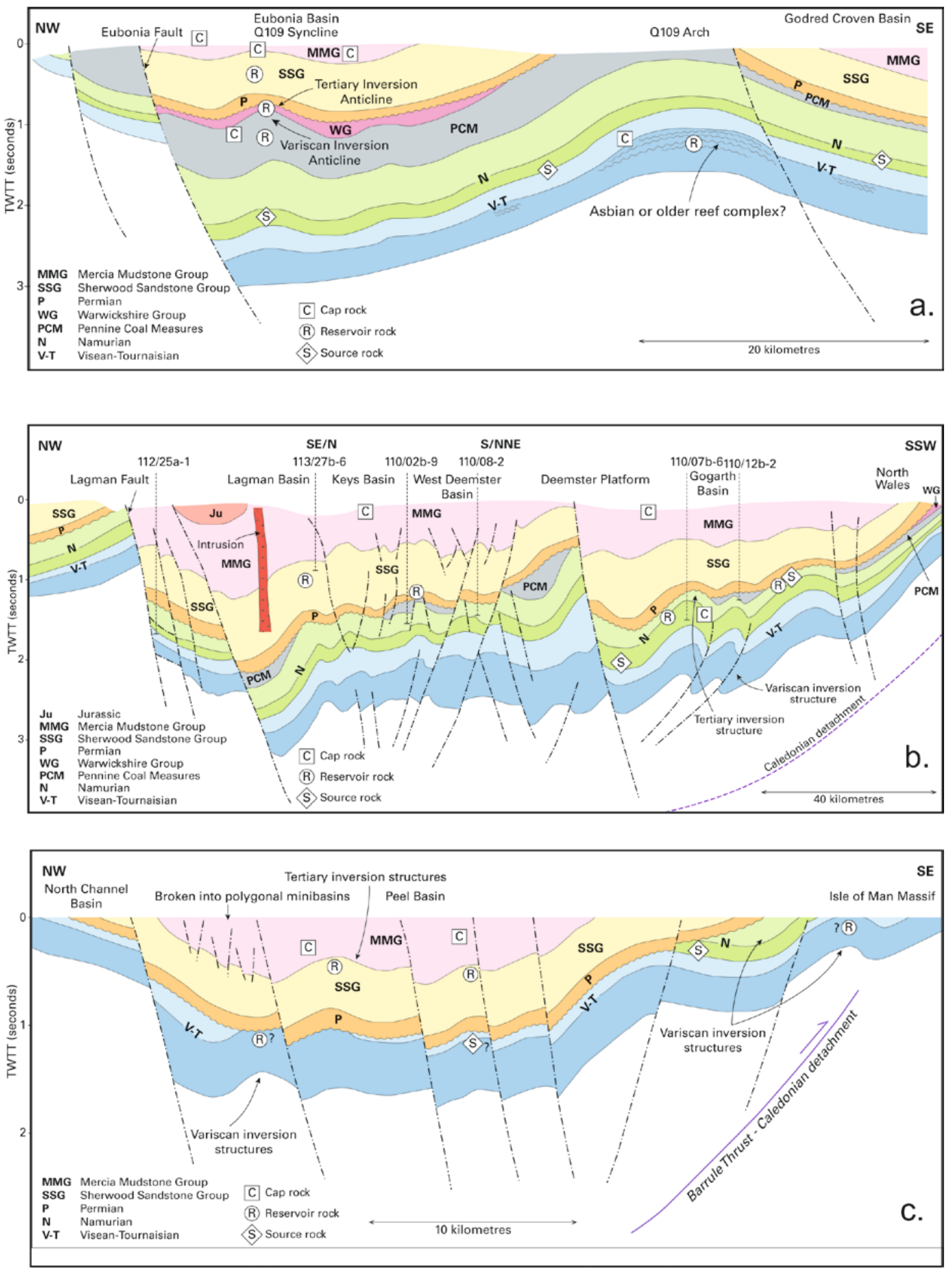

Fig. 4a, b, c 

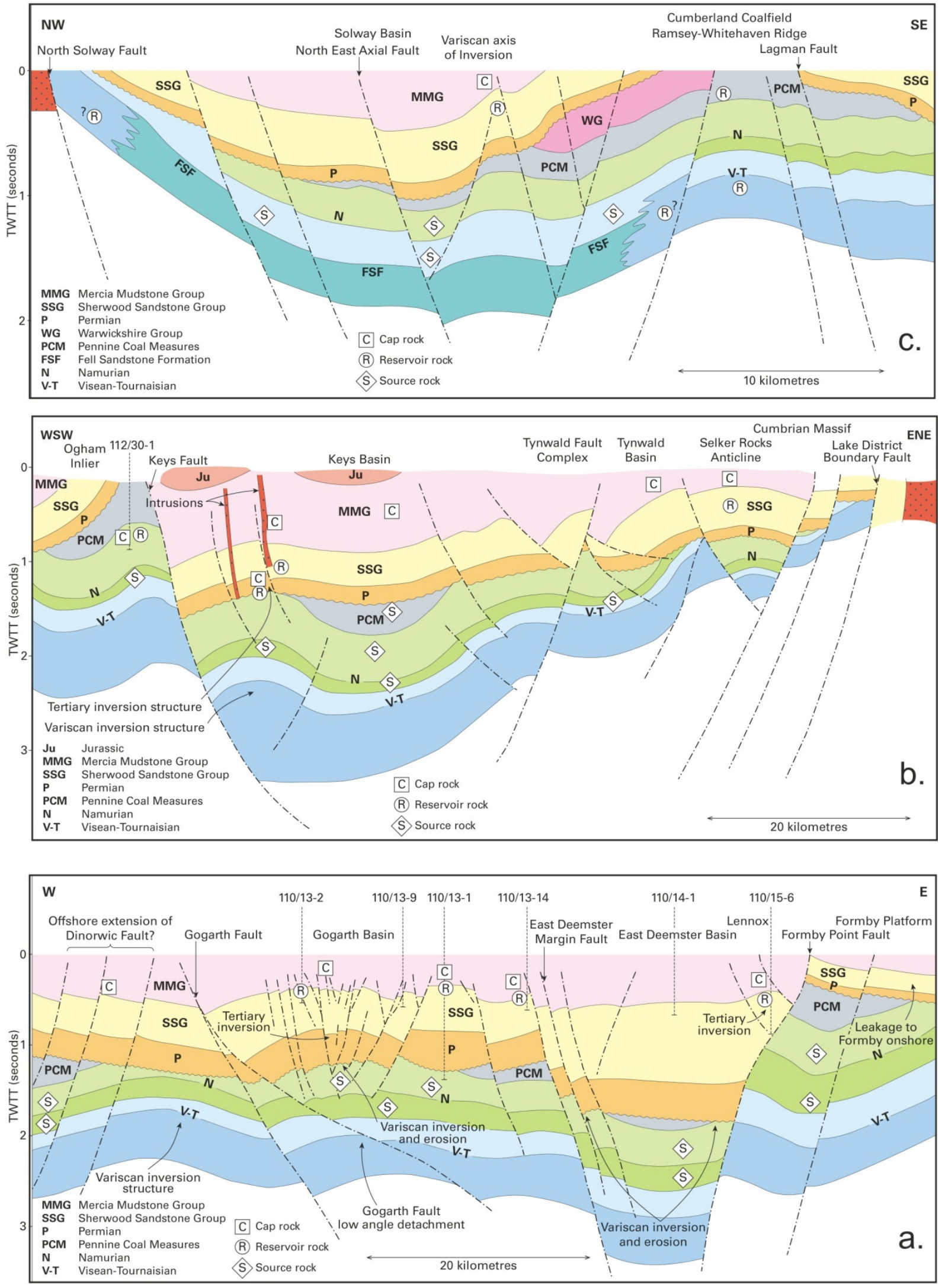

Fig. 5a, b, c 


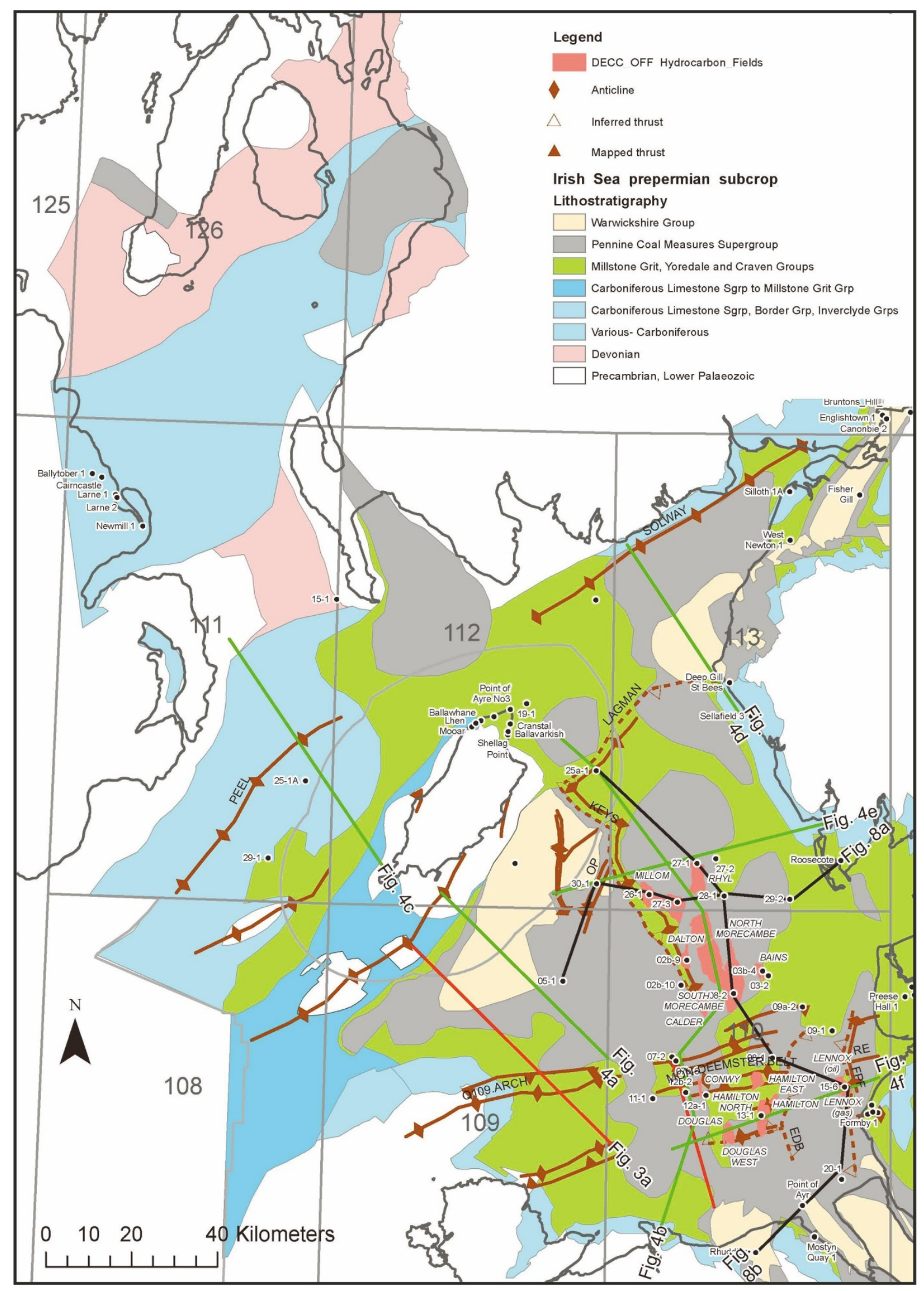

Fig. 6 


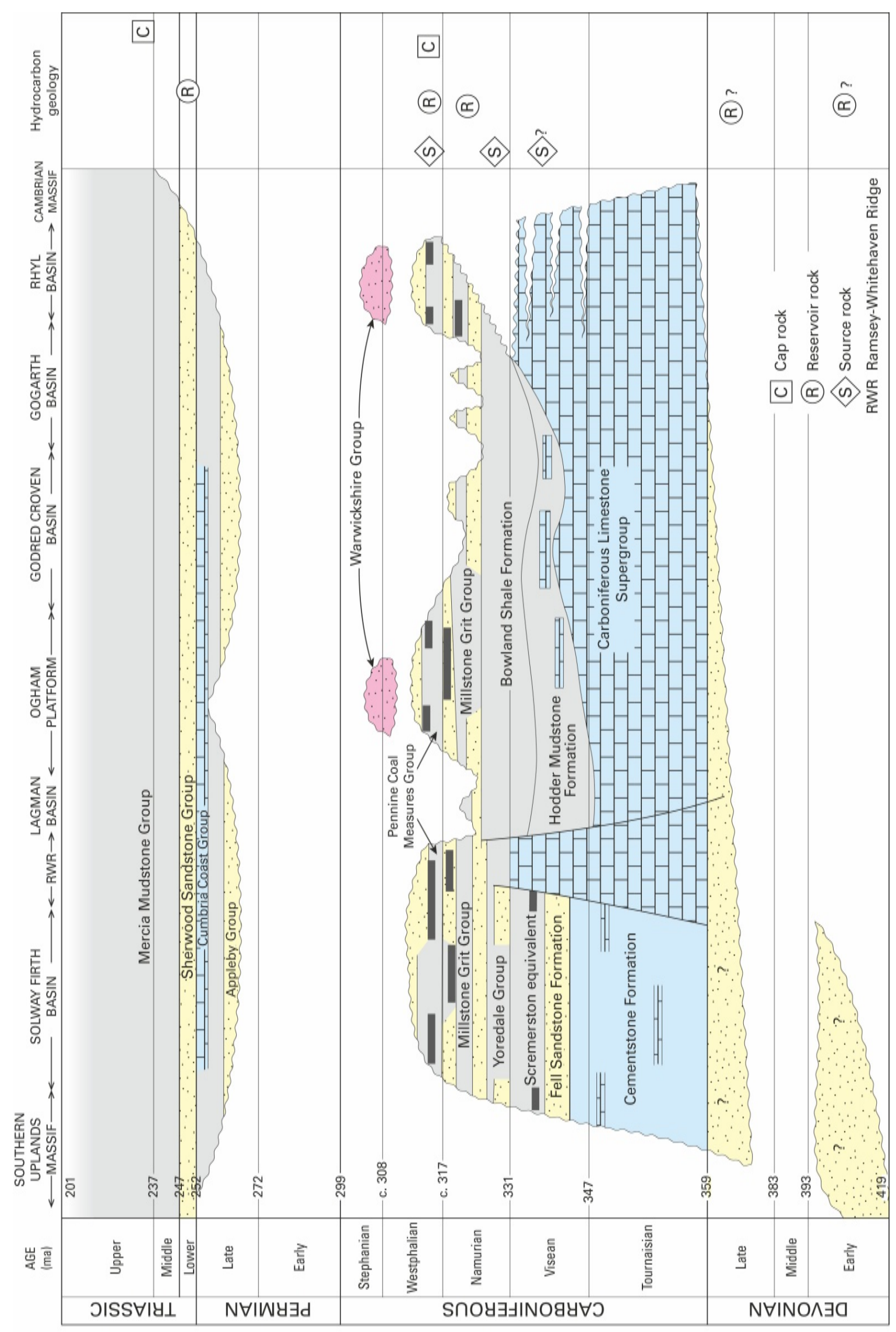

Fig. 7 


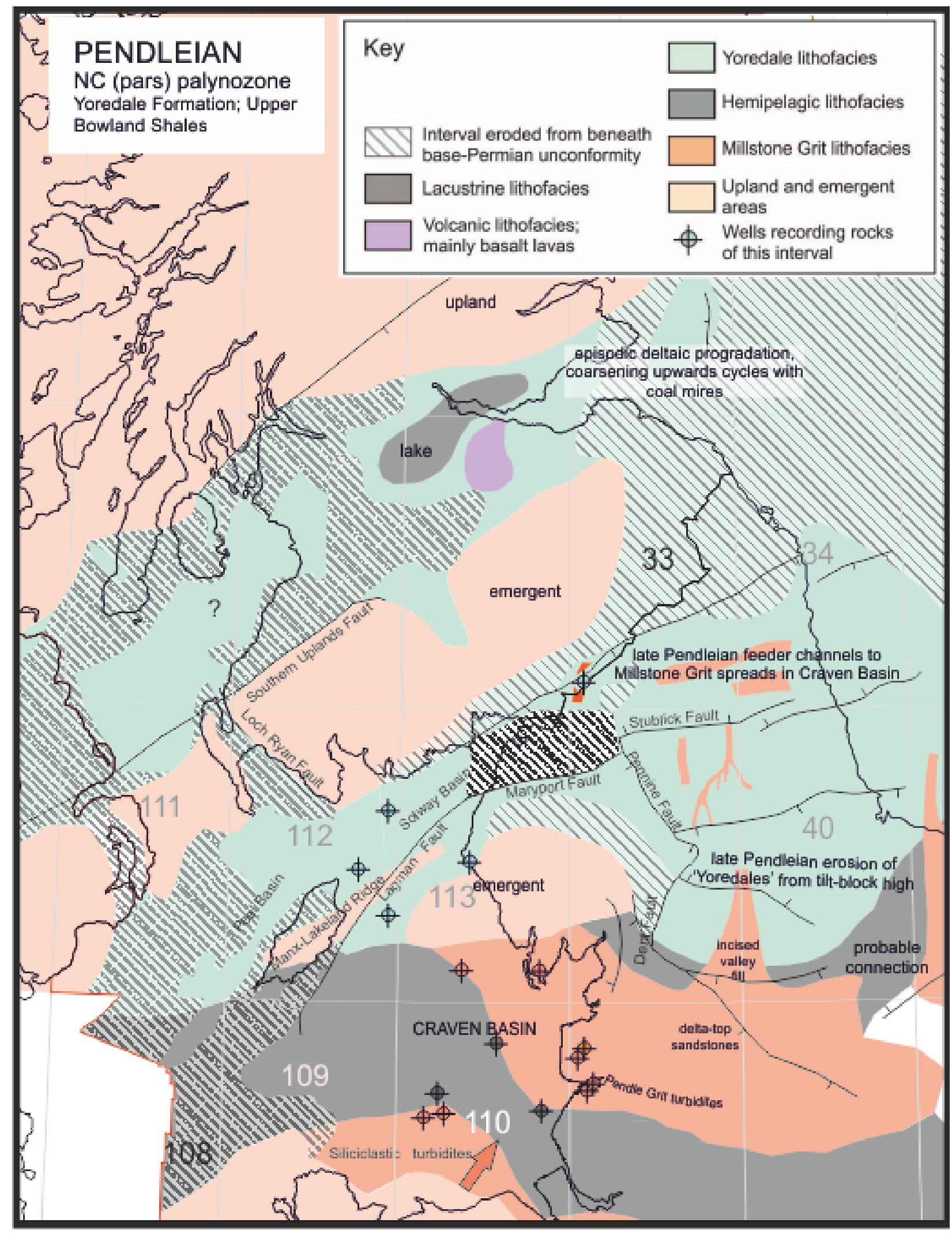

Fig. 8 


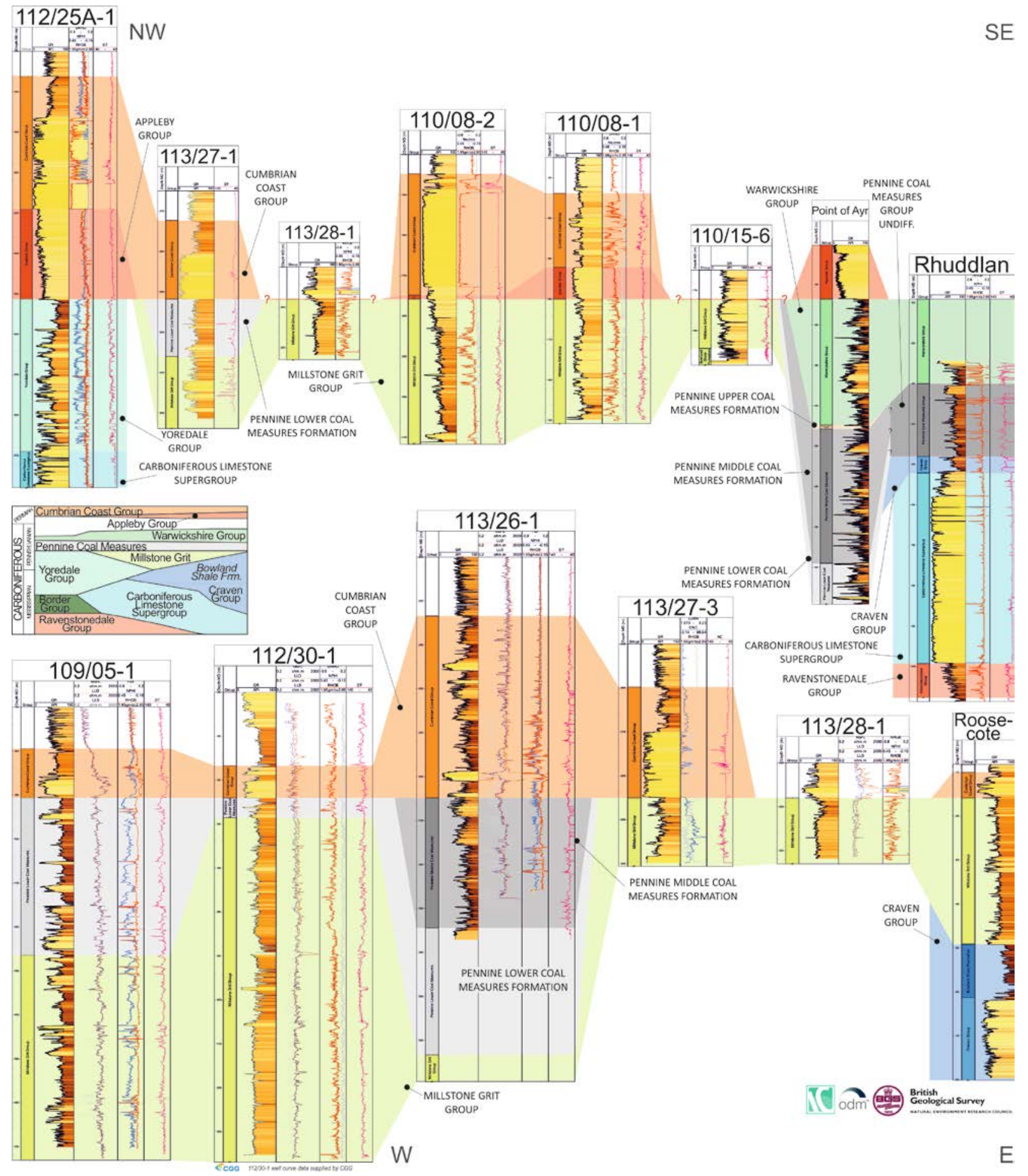

Fig. 9a, b 


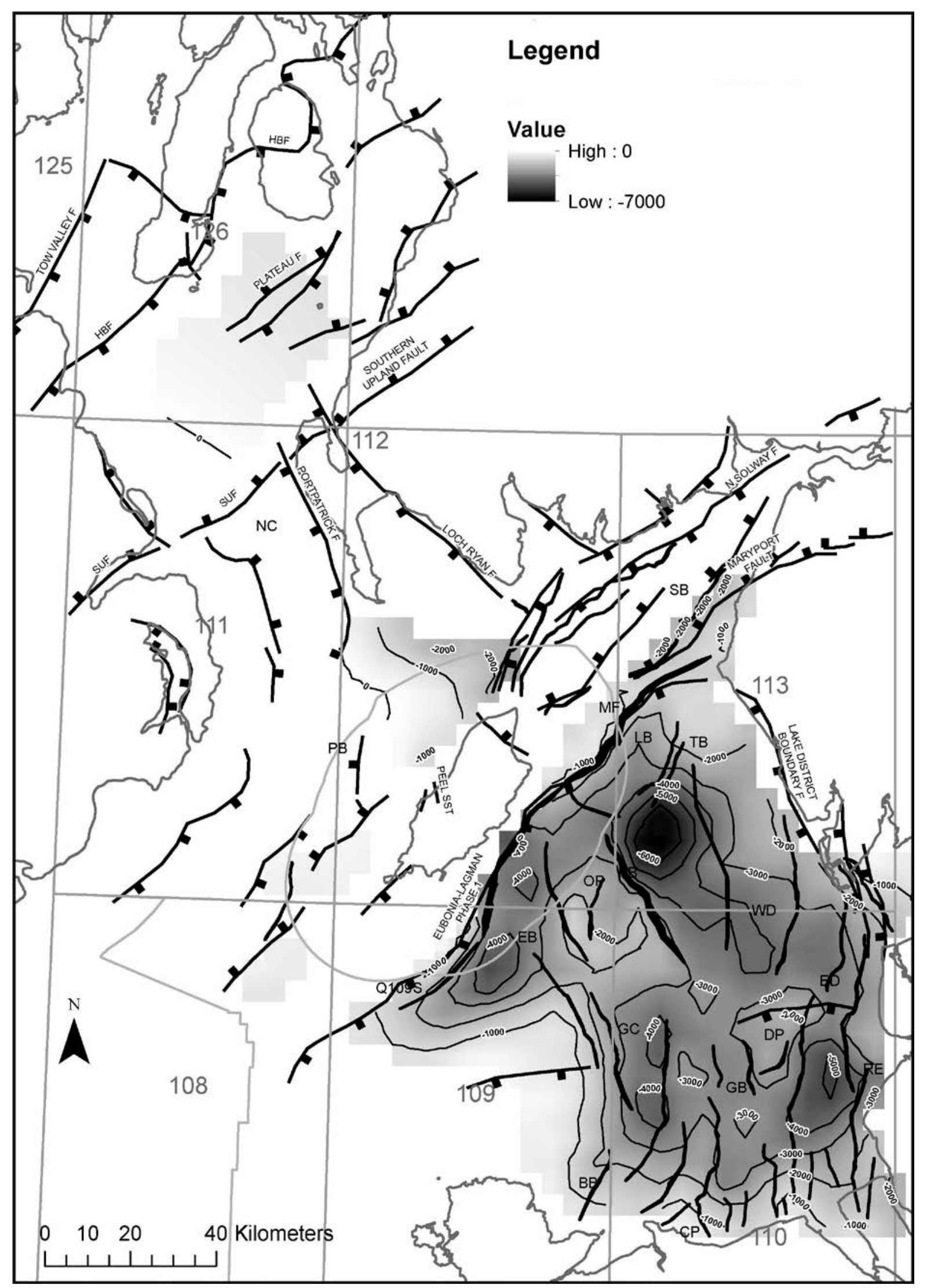

Fig. 10 


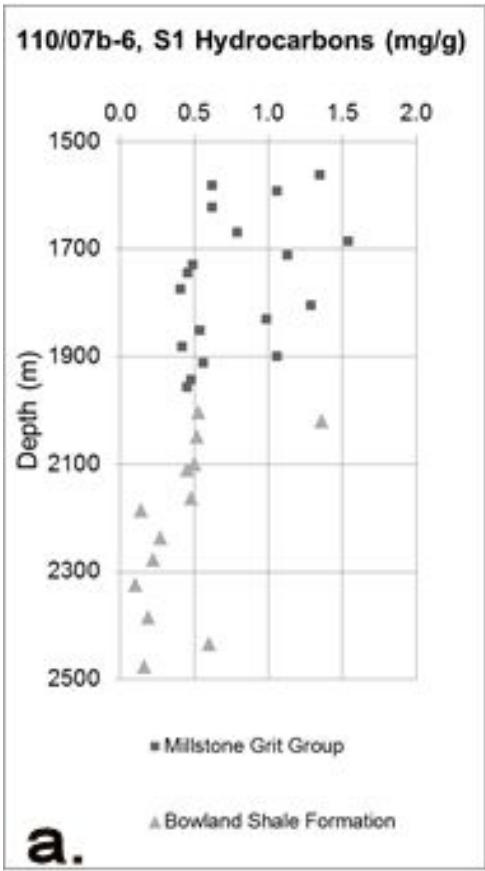

110/07b-6, VR (Ro measured)

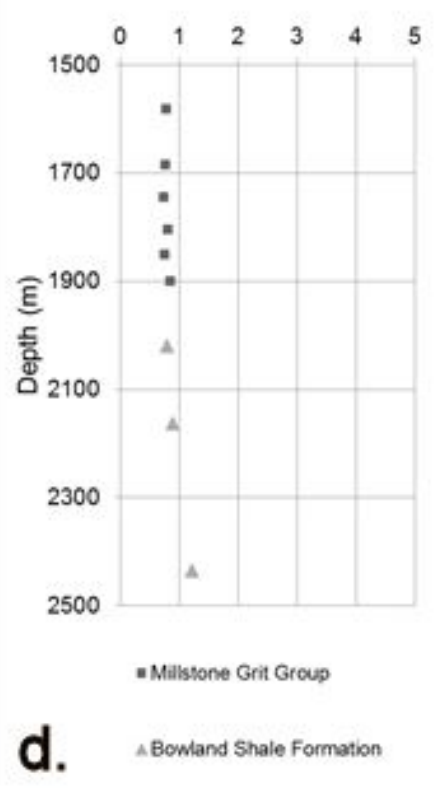

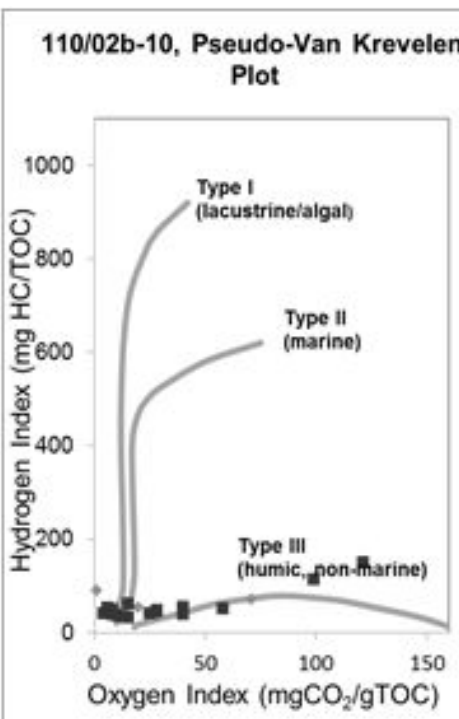

- Pennine Lower Coal Measures Formation

b.

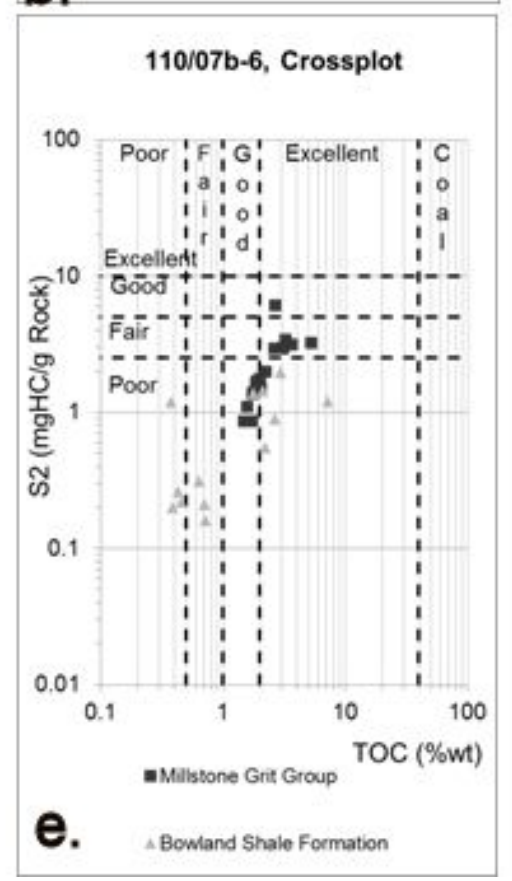

110/07b-6, Oil \& Gas Windows

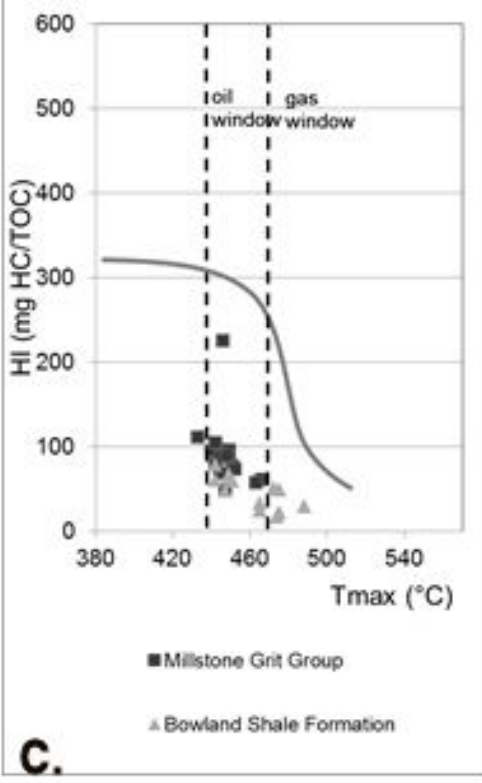

110/07b-6, Oil Prone \& Gas Prone Plot

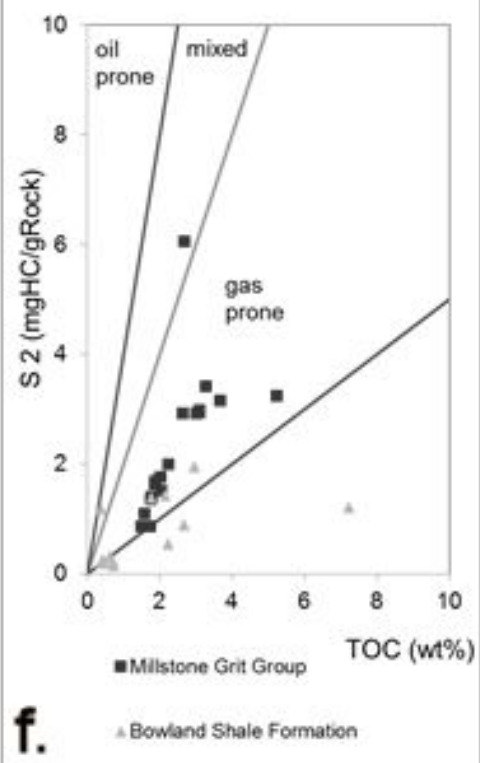

Fig. 11 


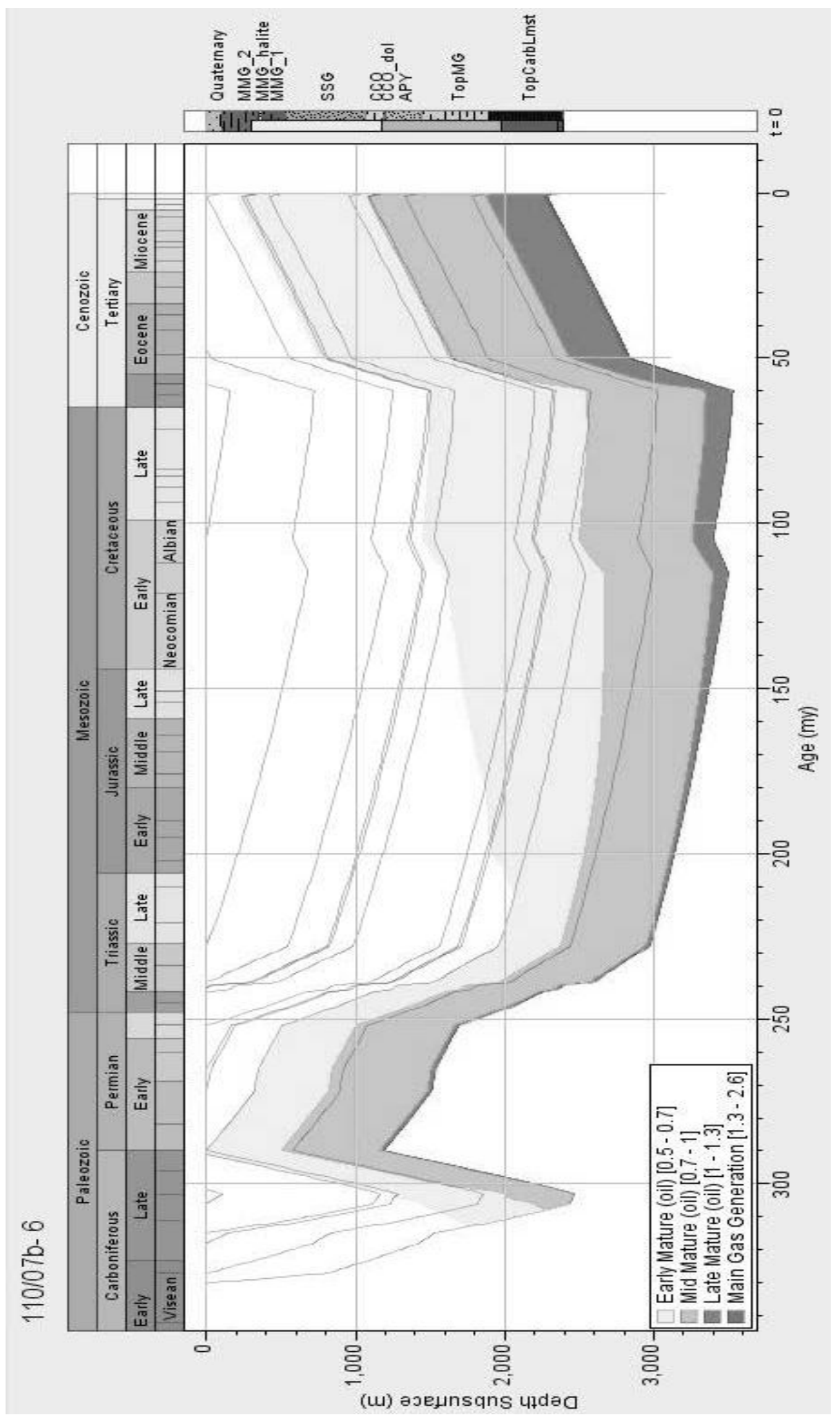

Fig. 12 


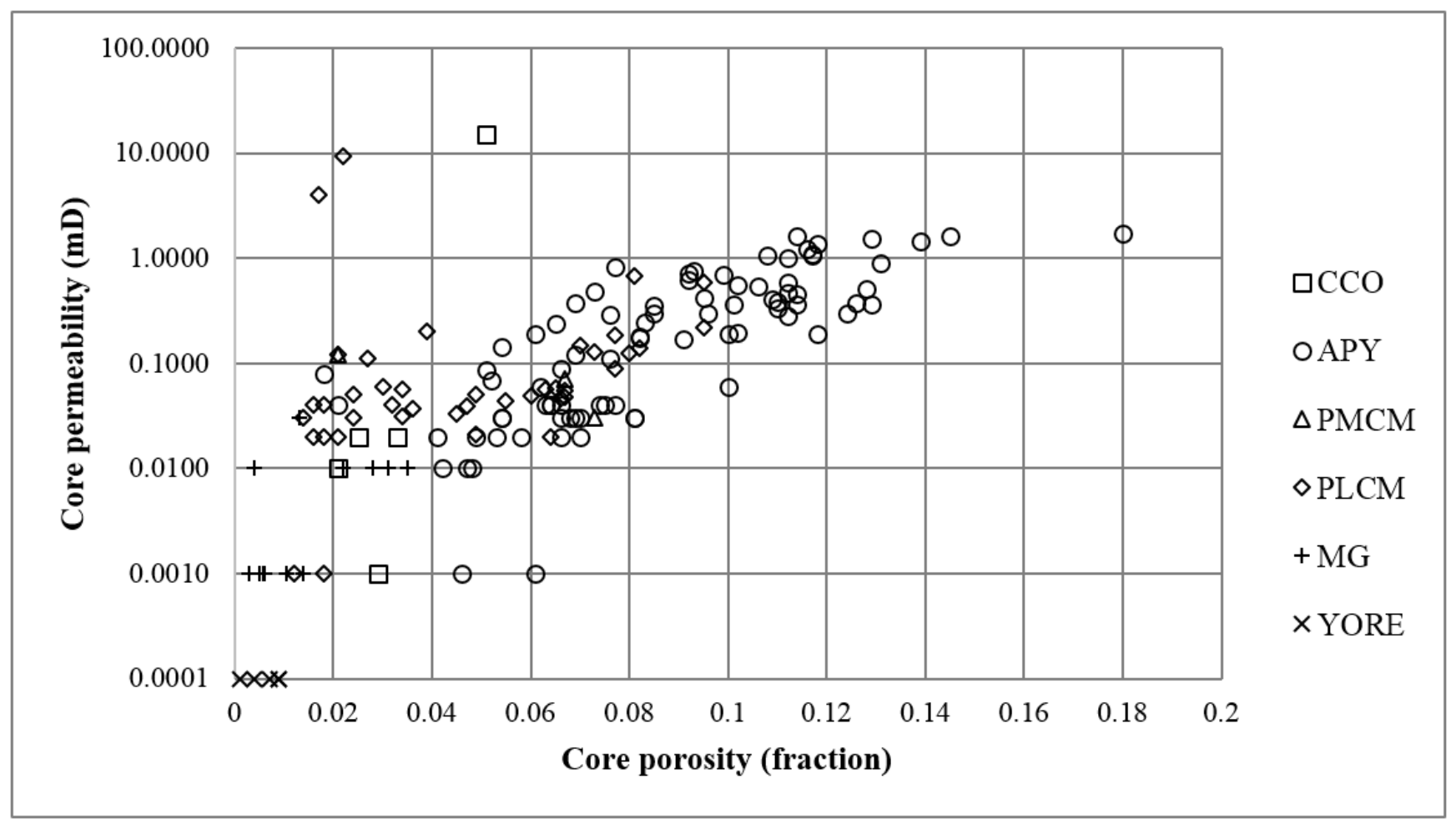

Fig. 13 


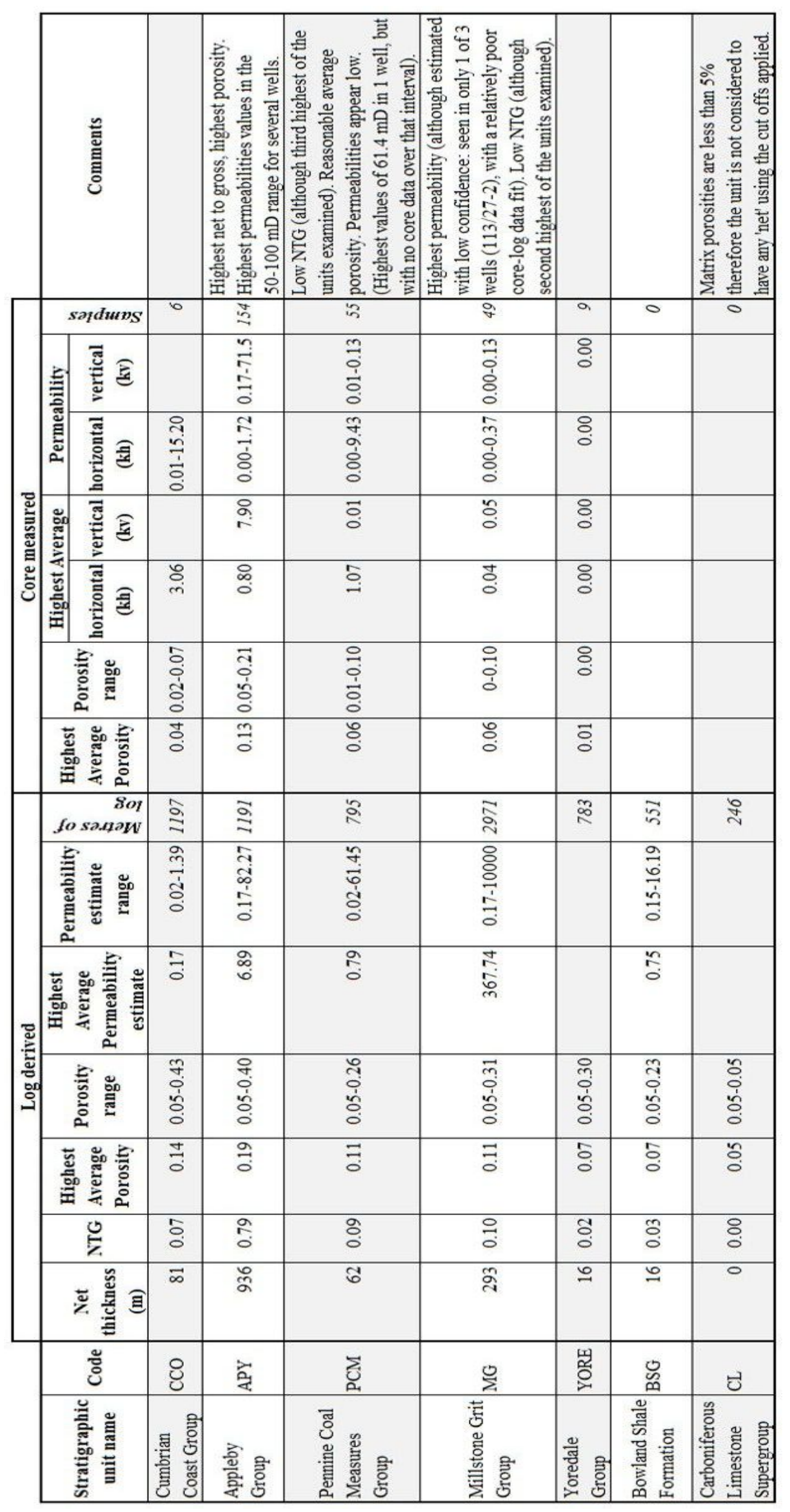

Table 1 


\title{
An overlooked play? Structure, stratigraphy and hydrocarbon prospectivity of the Carboniferous in the East Irish Sea-North Channel basin complex
}

\author{
T. C. PHARAOH ${ }^{1 *}$, C. M. A. GENT ${ }^{1}$, S. D. HANNIS ${ }^{2}$, K. L. KIRK ${ }^{1}$, A. A. MONAGHAN ${ }^{2}$, \\ M. F. QUINN ${ }^{2}$, N. J. P. SMITH ${ }^{1,3}$, C. H. VANE ${ }^{1}$, O. WAKEFIELD ${ }^{1} \&$ C. N. WATERS ${ }^{1}$ \\ ${ }^{1}$ British Geological Survey, Environmental Science Centre, Keyworth, Nottingham, NG12 5GG \\ ${ }^{2}$ British Geological Survey, The Lyell Centre, Research Avenue South, Edinburgh, EH14 4AP
}

${ }^{3} 2$ Downsview Villas, Camp Road, Freshwater, PO40 9HR

"Corresponding author (e-mail: tcp@bgs.ac.uk)

\begin{abstract}
Seismic mapping of key Palaeozoic surfaces in the East Irish Sea - North Channel region has been incorporated into a review of hydrocarbon prospectivity. The major Carboniferous basinal and inversion elements are identified, allowing an assessment of the principal kitchens for hydrocarbon generation and possible migration paths. A Carboniferous tilt-block is identified beneath the central part of the (Permian to Mesozoic) East Irish Sea Basin (EISB), bounded by carbonate platforms to south and north. The importance of the Bowland Shale Formation as the key source rock is reaffirmed, the Pennine Coal Measures having been extensively excised following Variscan inversion and pre-Permian erosion. Peak generation from the Bowland source coincided with maximum burial of the system in late Jurassic/early Cretaceous time. Multiphase Variscan inversion generated numerous structural traps whose potential remains underexplored. Leakage of hydrocarbons from these into the overlying Triassic Ormskirk Sandstone reservoirs is likely to have occurred on a number of occasions, but currently unknown is how much resource remains in place below the Base-Permian unconformity. Poor permeability in the Pennsylvanian strata beneath the Triassic fields is a significant risk; the same may not be true in the less deeply buried marginal areas of the EISB, where additional potential plays are present in Mississippian carbonate platforms and latest Pennsylvanian clastic sedimentary rocks. Outside the EISB, the North Channel, Solway and Peel basins also contain Devonian and/or Carboniferous rocks. There have however been no discoveries, largely a consequence of the absence of a high quality source rock and a regional seal comparable to the Mercia Mudstone Group and Permian evaporites of the Cumbrian Coast Group in the EISB.
\end{abstract}

The productive oil and gas fields of the EISB evidence a working, Carboniferous-sourced petroleum system. Whilst a great deal may be known of the Triassic reservoir and seal (Meadows et al. 1997), little is known about Carboniferous and Permian petroleum systems at depth and in adjacent basins, that may offer significant additional potential. The presence of a Palaeozoic hydrocarbon system in the East Midlands and southern North Sea is well documented however (Fraser et al. 1990; Fraser \& Gawthorpe 2003; Besly 1998). Following the Wood Review (2014), Palaeozoic plays, including that of the greater Irish Sea area were identified as priority for building regional digital datasets and stimulating exploration. In response, the $21^{\text {st }}$ Century Exploration Roadmap: Palaeozoic Project running from 2014-2016 and openly released in 2017, undertook regional scale seismic and well interpretation, source and reservoir screening studies and basin modelling. This paper provides a re-interpretation of the structural history of the greater Irish Sea, and its influence on potential Carboniferous and Permian prospectivity including the marginal basins.

The Carboniferous structure and stratigraphy of the UK sector of the East Irish Sea-North Channel region has been reviewed using all available well and seismic reflection data. The project interpreted about $40,000 \mathrm{~km}$ of 2D seismic data of many vintages from 1980-2000, with local infill from 3D data, to generate time and depth-converted surfaces for key Palaeozoic horizons (Pharaoh et al. 2016a). Priority was given 
to the interpretation of long regional speculative lines, with infill from licence- and prospect-scale surveys. These surfaces were then used as the basis for an assessment of Palaeozoic hydrocarbon prospectivity (Pharaoh et al. 2016b), which forms the core of this paper. For brevity, the seismic interpretations are summarised using synoptic diagrams ('cartoons'). The present economic focus of the hydrocarbon province is the Morecambe Bay gasfield and its satellites, located within the EISB, a basin complex of Permian to Mesozoic age comprising a number of mainly N-S oriented graben and intervening platforms (BGS 1994; Jackson et al. 1987, 1995, 1997). Together with the Worcester Graben and Cheshire Basin of the UK onshore, it forms part of the major Permian rift system extending through the north European province of the Pangaea Supercontinent (Ziegler 1990; Coward 1995; Chadwick \& Evans 1995; Scheck-Wenderoth $e t$ al. 2008). The principal structures of the EISB are strongly discordant to those in the pre-Permian substrate, which bear the imprint of a long and complex evolution culminating in the Variscan Orogeny in latest Carboniferous time. For these Devonian and Carboniferous tectonic elements, a new terminology is presented here and the lithostratigraphical nomenclature of Waters et al. (2011) is used to integrate onshore and offshore successions, allowing more precise correlation than the scheme introduced by Jackson et al. (1997).

The Bowland Shale Formation is recognised as a prolific source of gas for the Permo-Triassic reservoirs (Armstrong et al. 1997), but potential Namurian and Westphalian reservoirs suffer from low porosity and permeability due to the combined effects of Variscan inversion, deep burial in a PermianMesozoic rift, Cenozoic inversion, magmatism and thermal effects associated with the rifting of the North Atlantic (Meadows et al. 1997; Quirk \& Kimbell 1997). Several areas on the margins of the EISB (ManxFurness Ridge, Cumbrian margin, Fylde margin, Cambrian margin) are underlain by the offshore extensions of onshore coalfields or Namurian strata. These areas are covered in some detail by seismic data, and the availability of onshore analogues allows a more realistic assessment in terms of potential for development of non-conventional resources, perhaps from coastal locations.

\section{Methodology and datasets}

The exploration datasets used in the regional interpretation are depicted in Fig. 1. The 2D seismic datasets include regional speculative data supplied by geophysical companies (CGG, IHS and WesternGeco); licence- and prospect-level datasets provided by the Common Data Access Initiative (CDA) offshore and United Kingdom Onshore Geophysical Library (UKOGL) nearshore and onshore; and data supplied directly by participating companies (Centrica plc). The 3D dataset used was supplied by CDA, augmented by data from the 3D Terracube supplied by CGG. The well picks were supplied from the DECC well database at BGS Edinburgh, with further interpretation during the project.

\section{Pre-Carboniferous structural evolution}

The crust of the southern part of the region (North Wales, Anglesey and adjacent offshore areas (Fig. 2) was generated as volcanic and sedimentary complexes in magmatic arc-trench systems during late Proterozoic time. Many early tectonic lineaments (e.g. the Menai Strait Fault Zone; Gibbons 1987) are associated with the accretion and dispersal of various terranes along the margins of Gondwana in Neoproterozoic to Cambrian time. Many of the lineaments (Dinorwic, Berw) have a SW-NE trend, are relatively straight (implying steep upper crustal geometry) and have been serially reactivated in Acadian sinistral transpression, Devono-Carboniferous extension etc. The crust of the northern part of the area (Midland Valley, Scottish Highlands) was generated throughout Proterozoic time. A Neoproterozoic supracrustal metasedimentary sequence, the Dalradian Supergroup, was strongly deformed during the Grampian phase of the Caledonian Orogeny (Smith et al. 1999; Chew \& Strachan 2014). Its southern limit is marked by the Highland Boundary Fault, which forms the northern boundary of the area of investigation.

The crust in the central part of the region comprises early Palaeozoic sedimentary complexes belonging to several different terranes forming part of the Avalonian (Monian, Lakesman) and Laurentian 
(Southern Uplands, Midland Valley) margins of the Iapetus Ocean, and accreted during the Caledonian Orogeny (Bluck 2002; Barnes et al. 2006; Chew \& Strachan 2014). Numerous major tectonic lineaments have a typical SW-NE 'Caledonide' trend. These include the Carmel Head Thrust of northern Anglesey, and reactivations of the earlier Monian lineaments; the Ribblesdale Foldbelt (Kirby et al. 2000); the Causey Pike Thrust and Southern Borrowdale Lineament of the Lake District (Barnes et al. 2006); the numerous accretionary tracts of the Southern Uplands massif (Bluck 2002); and numerous faults with this trend within the Southern Highlands terrane (Chew \& Strachan 2014).

In this study, a NW-dipping zone of enhanced reflectivity in pre-Carboniferous 'basement', previously referred to as the Barrule Thrust (Chadwick et al. 2001), was mapped over a large area to NW of the Isle of Man. The analysis of the deep seismic reflection data presented by England \& Soper (1997) suggests that this structure lies within the Avalonian footwall of the Iapetus Suture, rather than representing the suture itself. A further zone of NNW-dipping basement reflectivity underlies the southern part of the EISB (Jackson \& Mulholland 1993; Pharaoh et al. 2016a; 2016b), being particularly prominent beneath the Conwy Platform, just off the north coast of Wales (Fig. 2). The dip of this zone steepens as it approaches the coast, and it is inferred to correlate with the southernmost strands of the Menai Strait Lineament, i.e. the Menai and Dinorwic fault zones. Although the seismic coverage is relatively poor in this area, the available data suggest that this zone represents the deepest regional detachment, with all subsequent extensional faulting (of Carboniferous and Permian-Mesozoic age) penetrating no deeper into the crust.

During the Acadian Phase of the Caledonian Orogeny, most of the lineaments identified above were reactivated within a sinistrally transpressive regime, associated with the late orogenic collapse of the Caledonian mountains chain, stretching from the Appalachians through Ireland and Scotland to Greenland and Norway (Chew \& Strachan 2014). The most obvious element of this regime is the Great Glen-Walls Boundary Fault system. Devonian strata are thickest in the north of the study area, in the Midland Valley and form the molasse to the Caledonian Orogen (Trewin \& Thirlwall 2002). In the south (Anglesey), Devonian strata are more limited in development and related to local faulted basin margins (Hillier \& Williams 2006). In this tectonic regime, W-E extension is anticipated (Coward 1993). Basins related to such an orientation are tentatively identified within the Orcadian Basin (Leslie et al. 2015) but are less clearly identified in the study area, except perhaps, in the rift basins (North Channel, Stranraer, Carlingford Lough) within the Southern Uplands Massif, and the Peel Sandstone Graben of the Isle of Man (Maddox et al. 1997; Parnell 1997; Quirk \& Kimbell 1997).

\section{Carboniferous structural and stratigraphic evolution}

An extensional- transtensional tectonic regime persisted into Carboniferous time (Leslie et al. 2016). Although a general W-E extensional regime has been invoked in Mississippian time (Coward 1993), extension occurred on faults with a diversity of orientations, but with reactivation of earlier basement structures (of various trends) being a common feature, e.g. in the Northumberland Basin (De Paola et al. 2005). This reflects partitioning of the tectonic regime (Leslie et al. 2015). East of the study area, in Lancashire, the Bowland Basin reflects deeper water deposition in a basin bounded by SW-NE trending faults (Pendle Monocline etc) representing reactivations of earlier basement structures (Kirby et al. 2000). The Solway Basin is the offshore continuation of the Northumberland Basin (Chadwick et al. 1995), and is controlled by major bounding faults on a SW-NE trend. The Peel Basin along strike to the SW, has a similar trend but opposite structural polarity and a very different basin setting in the Carboniferous (Fig. 2). However the evolution of both basins appears to have been strongly influenced by the extensional reactivation of underlying structures in the Caledonide basement. The Midland Valley (and Firth of Clyde basins) also exhibit a SW-NE trend, which persists up to the Highland Boundary Fault.

\section{Carboniferous extensional basins}

The Carboniferous substrate of the EISB comprises a number of basin elements, comparable to that of the UK onshore. Fig. 2 presents a speculative reconstruction of the principal tectonic elements in Mississippian time. It is based heavily on seismostratigraphic and structural interpretation, as only five offshore boreholes 
penetrate Visean strata in the whole of the province (112/25a-1 and 113/27-2 in the EISB; 111/25-1A and 111/29-1 in the Peel Basin; and 112/19-1 in the Solway Basin, Fig. 2). In the centre of the EISB, a major basin, here referred to as the Eubonia Tilt-Block (Fig. 2), is inferred to extend from the Quadrant 109 (Q109) Syncline in the SW (BGS 1994) to the Ogham Platform (Fig. 2). Extension farther east, beneath the Lagman and Tynwald (Permian-Mesozoic) basins of the EISB, towards the western edge of the Lake District, is also inferred. The presence of a major half-graben (tilt-block), controlled by a major syndepositional bounding fault on its NW margin, the Eubonia-Lagman Fault System (Fig. 2, 3a), is indicated by the seismic reflection data. The structure was not identified as a tilt-block by Jackson \& Mulholland (1993; p800), but they did recognise the marked asymmetry of the northern limb of the Q109 Syncline/Basin and the presence of up to $7.5 \mathrm{~km}$ of Visean to late Westphalian (and possibly Stephanian) strata. Fig. 3a shows a seismic line extending SE from the Isle of Man towards Anglesey (Fig. 2). It demonstrates the presence of over $2.5 \mathrm{~s}$ Two-Way Travel Time (TWTT) of Carboniferous strata east of the Eubonia Fault, in what is referred to as the Eubonia Tilt-block (Pharaoh et al. 2016b). Poor well control is provided by a few distant wells on the western edge of the EISB (Fig. 2) and the picks are not well constrained.

Towards the top of the tilt-block in the south, on the Holy Island Shelf, brighter reflectivity in the upper Visean interval, may represent the development of reefal carbonates. The southern end of the section crosses a northward-vergent inversion anticline-thrust couple, defining the northern limit of the MônDeemster Fold Belt. This is a 25-30 km wide belt of strong Variscan inversion, extending ENE from the north coast of Anglesey, from the Q109 Arch to the Deemster Platform (Fig. 2). The internal structure of this belt is imaged on numerous N-S profiles crossing the Godred Croven Basin, and Fig. 3b, an arbitrary line through 3D data in this area, is representative. A schematic profile is presented in Fig. 4b. A series of parallel WSW-ENE trending anticlinal folds has been mapped through the area. The internal structure of this inversion belt is complex, comprising a fan-like array of anticlines and synclines with associated thrusts, SSE-vergent in the south, and NNW-vergent in the north (Fig. 4b). Fig. 3b clearly shows discordant reflections in the Visean sequence, extending down into the Caledonian basement, interpreted here as faultplane reflections. Below 3s TWTT, a further zone of intra-basement reflectivity is interpreted as a deeper Caledonian detachment surface, as recognised by Jackson \& Mullholland (1993; p805). Well 110/07b- 6 was clearly a test of the structure with the greatest amplitude, at the northern end of the profile. This slightly deviated well proved $450 \mathrm{~m}$ of (presumed) Namurian Bowland Shale Formation (Pendleian unbottomed) beneath $550 \mathrm{~m}$ of Millstone Grit Group, Westphalian strata being absent beneath the Base-Permian unconformity (Fig. 3b). As noted above, northward-vergent structures have been identified on the northern edge of the Q109 Arch (Fig. 3a), and they have also been mapped beneath the northern part of the Deemster Platform. Several NNW-SSE to N-S trending graben of the EISB (Godred Croven, Gogarth and East Deemster basins) discordantly overlie this Carboniferous hinge-zone. The inversion belt is very similar in its structure and orientation to the Ribblesdale Foldbelt of the Lancashire onshore, representing the Variscan-inverted Bowland Basin (Corfield et al. 1996; Kirby et al. 2000). It seems logical to infer connection of the two, via the Fylde coast of Lancashire, as proposed by Corfield et al. (1996). If this inference is true, then the southern edge of the zone may represent a reactivated extensional fault, analogous to the Pendle Lineament of Lancashire; and the Visean carbonate platform (Holy Island and Conwy platforms) to the south, with a thin or absent Namurian cover, are the equivalent of the Central Lancashire High (Kirby et al. 2000). Also by analogy with the Bowland Basin/Ribblesdale Fold belt onshore, the greatest thickness of Bowland Shale offshore was probably deposited within a rift basin ancestral to the presently observed Môn-Deemster inversion zone. Further seismic mapping is required to confirm this however.

That part of the Eubonia Tilt-block lying east of the Keys Fault was subsequently almost obliterated by the combined effects of latest Variscan inversion and pre-Permian erosion. The original eastern limit of the tilt-block is uncertain. It likely continued beyond the Tynwald Basin, where the en-echelon faults of the Lake District Boundary Fault System may have acted as transfer faults, offsetting extensional subsidence farther south into the Craven Basin. On the northern margin of the tilt-block, to NW of the Eubonia-Lagman 
Fault System, an extensive shallow marine carbonate platform developed in Visean time. This is well represented by outcrop in the south of the Isle of Man (Chadwick et al. 2001), the northern edge of the Lake District and adjacent offshore (Ramsey-Whitehaven Ridge) (Fig. 2). Because of significant pre-Permian uplift and erosion, it is not possible to determine the subsidence regime in which Westphalian strata were deposited, but it was probably dominated by post-extensional thermal subsidence, as elsewhere in southern Britain, the depocentre lying near Manchester (Fraser et al. 1990; Fraser \& Gawthorpe et al. 1990).

A few wells penetrate the Carboniferous sequence beneath the Peel Basin (Fig. 2) and demonstrate north towards the North Channel. The present study revealed that the undifferentiated Carboniferous strata on BGS (1994) mapping are principally of Visean age, Namurian strata being largely eroded (Pharaoh et al. 2016a). The Permo-Triassic Peel Basin has the form of an asymmetrical graben controlled by a major bounding fault on the northern side (Fig. 4c), and extensional faults with smaller throws on the southern side, developed in the hangingwall of the Barrule Thrust (Chadwick et al. 2001). Lack of evidence for significant Carboniferous syndepositional throw, and the larger Permo-Triassic throws, suggests that there was probably not a significant basin here in Visean time, although the poor quality of the seismic data allows some uncertainty. Faulting at the top of the Appleby Group (Permian) has a predominantly NW-SE trend (Quirk et al. 1999), akin to that of the North Channel Basin.

In contrast, the Solway Basin, underlying the Permian-Mesozoic Carlisle Basin along strike to NE of the Peel Basin, is asymmetrical with a principal controlling fault on the southern side (RamseyWhitehaven Ridge) (Fig. 5a). The Carboniferous basin fill comprises fluviodeltaic Border and Yoredale Group strata with greater affinity to the Northumberland Trough sedimentary sequence than the carbonate platforms of the southern Irish Sea (Chadwick et al. 1995), together with a greater thickness of preserved Pennsylvanian strata.

The present study found no convincing evidence for the presence of significant thicknesses of Carboniferous strata beneath Permo-Trias in the Portpatrick Basin, the southern part of the North Channel Basin complex: the only well to penetrate Permian in this basin (111/15-1) unfortunately terminated in early Palaeozoic rocks having passed through the marginal fault. The absence of Carboniferous strata may be a consequence of erosion following late Variscan inversion on the NNW-trend (see below). However, they are present within re-entrants at the northern edge of the Southern Upland Massif (Stranraer, Strangford Lough), and are certainly present to north of the Southern Upland Fault (Larne, Rathlin basins and SW Arran Trough). All of these basins are very poorly explored by deep boreholes and only very general conclusions can be made about their Mississippian evolution, largely by inference from nearby analogues onshore (Read et al. 2002).

\section{Early phase of Variscan inversion}

Through Pennsylvanian time, the impact of the Variscan Orogeny resulting from the collision of numerous Gondwana-derived terranes (Armorica, Central Massif, Bohemian Massif etc) with the southern margin of Laurussia (Ziegler 1990; Pharaoh et al. 2006) became increasingly evident in Britain. Large-scale northward thrust and nappe emplacement occurred in southern Britain, S Wales and S Ireland, but the region lay in the northern foreland of the Variscan Foldbelt (Besly 1988; Ziegler 1990; Pharaoh et al. 2010). In late Pennsylvanian (Westphalian C) time, an early phase of inversion was followed by deposition of strata of the Warwickshire Group, above a regional unconformity (Eastwood et al. 1937; Akhurst et al. 1997; Jones et al. 2011; Dean et al. 2011; Waters et al. 2011). The Whitehaven Sandstone Formation (equivalent to the Warwickshire Group and of latest Westphalian to ?Stephanian age) has divergent palaeocurrents to the south in Cumbria, and to the north at Canonbie, reflecting penecontemporaneous growth of the Solway inversion anticline (Jones et al. 2011). In the EISB, this study has identified SSW-ENE trending inversion structures parallel to the Eubonia-Lagman Fault System in the north (Fig. 6), as well as in the MônDeemster inversion belt described above. The study has shown that the early phase of Variscan inversion structures are cut discordantly by the NNW-SSE to N-S trending faults of the Permian-Mesozoic main graben structures of the EISB, such as the Keys Fault, Godred Croven Fault and western marginal fault of the East Deemster Basin. North of the Ramsey-Whitehaven Ridge, both the Solway and Peel basins suffered 
strong inversion on SSW-NNE 'Caledonoid' trends, with uplift and erosion of most of the post-rift (Namurian to Westphalian) successions, prior to deposition of Warwickshire Group strata (Jackson et al. 1995; Newman 1999). Variscan reversal of the Maryport Fault is demonstrated by the preservation of a much more complete post-rift sequence on its footwall block (Ramsey-Whitehaven Ridge) than in the Solway Basin, its hangingwall block (Chadwick et al. 1993).

\section{Later phase of Variscan inversion}

In late Pennsylvanian time, the final deformation phases of the Variscan Orogeny are associated with the closure of the Uralian Ocean basin and collision of the Kazakhstan and Siberian plates (Zonenshain et al. 1984; Puchkov 1997; Brown et al. 2002), resulting in W-E oriented compressional stress (Coward 1993; 1995). In the study area, inversion occurred along NNW-SSE to N-S trending faults such as the Keys Fault, Gogarth Fault, the western marginal fault of the East Deemster Basin and the Formby Point Fault System. Evidence for this is provided by the Carboniferous subcrop pattern presented by BGS (1994). The PrePermian subcrop inset in the marginalia of this map clearly shows erosion of Westphalian strata in NNWto N-S trending belts associated with the hangingwalls of the Keys Fault (Fig. 5b), Gogarth Fault (Fig. 4a) and Lake District marginal faults (Fig. 5c). By contrast, Westphalian strata are well preserved on the footwall of these structures. The seismic data indicate the presence of N-S trending anticlinal folds cored by Namurian strata, dissected by faulting on their overturned limbs. Similar subcrop patterns, with Namurian subcrops in the cores of Variscan inversion anticlines e.g. the Murdoch Anticline, are observed in Quadrants 43 and 44 in the southern North Sea (Corfield et al. 1996), and indeed, the two basins exhibit a similar degree of inversion. At present the NNW-SSE to N-S trending faults are extensional structures of Permian and younger age; but these are here inferred to have initiated as thrusts or positive flower structures ('ancestral faults') on the overturned limb of the anticlines during Variscan inversion, as reported in the Ogham Inlier by Quirk \& Kimbell (1997). A component of sinistral shear is likely from the observed study (Fig. 6) confirms the pre-Permian subcrop pattern presented by BGS (1994) and has identified a possible interference structure between the two trends in the Ribble Estuary Inlier. Although it is conceivable that inversion on faults with both WSW-ESE and NNW-SSE trends could have occurred in one Variscan phase of inversion, comparable to the partitioned deformation system advocated for the Northumberland Basin by De Paola et al. (2005), the above evidence would appear to suggest two, separate, nearly orthogonal phases of Variscan inversion are more likely. Extensional reactivation of the ancestral late Variscan structures in W-E extension during Permian to Mesozoic time, facilitated development of NNW-SSE to N-S trending graben of the EISB, strongly discordant to the strong SW-NE structural grain established by Caledonian compression, Mississippian extension and early Variscan inversion. Strong uplift and erosion during the Variscan inversion led to complete removal of the Pennine Coal Measures strata underlying the Lagman Basin. The ancestral Keys Fault played a key role in partitioning the former Eubonia Tilt-block into western and eastern segments, the latter being almost obliterated by post-Variscan events. Inversion on the same trend may have led to uplift and erosion of Carboniferous strata deposited within basins on the North Channel Basin complex.

\section{Post-Variscan structural evolution}

The post-Variscan structural evolution of the EISB has been thoroughly described in numerous previous publications (BGS 1994; Jackson et al. 1987; 1995; 1997; Jackson \& Mulholland 1993). As a result, only a generalised account, focussing on those elements where the Palaeozoic structure has a bearing, will be presented here. Following the Variscan basin inversion and regional uplift described above, there is clear evidence on seismic profiles for the erosion of Pennine Coal Measures strata from the crests of inversion anticlines, and tectonic dissection of the latter adjacent to the Keys, Lagman, Lake District Boundary and Formby Point faults prior to deposition of Permian strata (BGS 1994). Jackson \& Mulholland (1993; p793) and Jackson et al. (1997; Figure 2) recognised significant thickening of the Appleby Group (Lower Permian), possibly to as much as $1150 \mathrm{~m}$ (Jackson \& Mulholland 1993), in a belt extending from the Berw 
Basin to the Formby Oilfield. For example, the well 110/11-1 proved $763 \mathrm{~m}$ of Collyhurst Sandstone Formation (Appleby Group), while 110/7-2 $12 \mathrm{~km}$ to the north proved only $40 \mathrm{~m}$, and none is present in the vicinity of the Morecambe fields. The belt of thick Appleby Group strata directly overlies the Môn Deemster Foldbelt, providing strong evidence for significant early Permian penecontemporaneous relief within, and deep erosion of, the tectonically weakened inversion belt. The area must have had a substantial topography in early Permian time. It is interesting to note that significant pre-Permian palaeotopography was described at Formby by Falcon \& Kent (1960).

A series of NNW-SSE to N-S trending rifts began to develop in response to W-E extension affecting the crust of the Pangaea Supercontinent that was established during the Variscan Orogeny (Whittaker 1985; Coward 1995; Chadwick \& Evans 1995). In the Worcester and Knowle basins onshore, rifting was able to exploit the N-S ('Malvernoid') grain previously established by late Precambrian orogeny (Pharaoh 1987; Barclay et al. 1997) and subsequent Variscan inversion (Chadwick 1993). The rifts propagated with stepwise, en-echelon offsets through the province, from the Stafford and Cheshire basins and EISB through the Portpatrick and Larne basins and the North Channel to the western Scottish offshore basins (Ziegler 1990). The Solway and Peel basins subsided less than the EISB, and are elongated SW-NE, reflecting structural control by the extensionally-reactivated Caledonide basement structure within the Iapetus Convergence Zone. Nevertheless, it is notable that the majority of small to medium-sized intrabasinal normal faults (Chadwick et al. 2001) take up the new N-S trend, as in the Cheshire Basin (Chadwick 1997). By Triassic time, the EISB was a mature component of the Central European Basin System (Scheck-Wenderoth et al. 2007; Pharaoh et al. 2010), receiving up to $5 \mathrm{~km}$ fill of Sherwood Sandstone Group clastic sedimentary rocks and Mercia Mudstone Group mudstones and evaporites (Jackson \& Mulholland 1993). Small relict outliers of Lias (early Jurassic) strata in the Carlisle Basin (Warrington et al. 1997), Peel Basin (Chadwick et al. 2001) and EISB (Jackson \& Mulholland 1993) indicate that subsidence continued into Jurassic time. Evidence for mid- and late Jurassic subsidence has been removed subsequent to Cenozoic inversion, uplift and erosion. The magnitude of post-Triassic displacement is difficult to estimate due to this erosion, but it is likely that the Lagman and Keys faults, together with the Maryport, Portpatrick, Loch Ryan and St Patrick faults, suffered significant normal movement (Jackson \& Mulholland 1993; Quirk et al. 1999). Apatite fission-track analysis indicates that for parts of the Ramsey-Whitehaven Ridge, maximum post-Variscan burial was achieved in early Cretaceous time (Green et al. 1997). This was associated with peak generation of hydrocarbons from Carboniferous source rocks throughout the region. Soon after this, a fall in relative sea level and erosion resulted in the Late Cimmerian Unconformity, found throughout the British Isles (Whittaker 1985). The reduction in confining pressure may have been enough to allow early formed hydrocarbons, principally oil, to escape early reservoir structures in gentle roll-over anticlines associated with the shallow detachment tectonics in the centre of the Main Graben, towards roll-over traps at the marginal faults (Pharaoh et al. 2016b).

Opening of the Atlantic Ocean east of Greenland by Paleocene times associated with putative Icelandic Plume activity (e.g. Brodie \& White 1994; Nadin \& Kuznir 1995) resulted in voluminous magmatism in the Inner Hebrides and in N Ireland just to the west of the study area. The Fleetwood Dyke Complex (Kirton \& Donato 1985) was intruded en echelon across the main graben of the EISB. Magmatic and thermal processes on a lithospheric scale resulted in regional thermal doming of the crust below the EISB (White 1988) in Palaeogene or possibly, late Cretaceous, time (Cope 1994, 1997). Across the study area, the combination of enhanced regional and local heat flow led to a further phase of hydrocarbon generation (Cowan et al. 1997; Meadows et al. 1997). Superimposed on the regional, thermal uplift described above were the effects of later crustal shortening, associated with the developing Alpine Orogeny in southern Europe. Apatite fission-track data indicate a second Cenozoic phase of cooling at 25-20 Ma (Newman 1999), compatible with the region being affected by the Oligo-Miocene phase of inversion found in southern Britain and the southern North Sea (Van Hoorn 1987; Badley et al. 1989; Chadwick 1993). Inversion of the Solway Basin led to development of a major anticlinal structure in the hangingwall block of the Maryport Fault (Chadwick et al. 1993) on the northern side of the Ramsey-Whitehaven Ridge. On the southern side of the ridge, the reversal of the Lagman Fault led to the generation of small hangingwall 
anticlines (Chadwick et al. 2001). Flower structures and 'pop-up' structures are found along the Keys Fault and Formby Point Fault e.g. the Rhyl and Lennox fields (Haig et al. 1997), reflecting the 'buttressing' effect of the margins of the EISB (Pharaoh et al. 2016b). Throughout the EISB, seismic data indicate the presence of gentle Cenozoic inversion anticlines (Figs. 4a, b, c) superimposed on an earlier generation of Variscan inversion anticlines (Pharaoh et al. 2016a; b), the 'posthumous' tectonic style recognised by Jackson \& Mulholland (1993). Further tightening of the Variscan inversion anticlines during Cenozoic (Alpine) crustal compression resulted in the development of more open structures in the Permo-Triassic cover. This was likely an important process in the generation of the traps in the Hamilton fields (posthumous upon the MônDeemster inversion belt) and the Millom, Dalton and Calder fields (posthumous on the Keys trend of latest Variscan inversion). The Cenozoic inversion history is thus complex, involving contractional reactivation of precursor normal faults, posthumous folding and regional arching and uplift of basin depocentres, upon which various thermal effects due to magmatic intrusion and possible underplating have been superimposed. A detailed treatment of these potential Cenozoic impacts upon the Palaeozoic hydrocarbon system is beyond the scope of this paper.

\section{Petroleum systems of the Carboniferous basins of the EISB}

In the EISB, a proven petroleum system is present, involving a Carboniferous source (Colter \& Barr 1975; Cowan 1991; Stuart 1993; Armstrong et al. 1997), reservoirs of the Ormskirk Sandstone, locally the uppermost formation of the Triassic Sherwood Sandstone Group, and halite seals (Fig. 7). A substantial number of exploration wells have been drilled, but few penetrate the Permian and the potential pre-Permian resource underlying the EISB fields is poorly known. The North and South Morecambe gasfields (Fig. 6), with a combined in place recoverable of 5.2 tcf (Cowan 1996), were discovered in the 1970s and lie in large regional anticlines associated with rollover and salt-facilitated low angle detachment faulting, of Triassic to Jurassic age (Knipe et al. 1993). Further modification of trap geometry occurred in Miocene time as a result of Alpine inversion. An initial charge of hydrocarbons (probably mostly oil) in Jurassic time was originally thought to have been derived from Pennine Coal Measures source rocks, as in the southern North Sea (Bushell 1986). Subsequently the Bowland Shale Formation was confirmed as the source (Armstrong et al. 1997). This early charge was associated with the formation (at about $180 \mathrm{Ma}$ ) of a 'platy-illite' layer, interpreted as a palaeo-hydrocarbon-water contact (Bushell 1986; Woodward \& Curtis 1987; Knipe et al. 1993), which was lost during the early Cretaceous and the present (mostly) gas charge is believed to result from a further cycle of hydrocarbon generation (also from the Bowland Shale Formation?) associated with an elevated geothermal gradient during the early Cenozoic (Cowan \& Bradney 1997). Hydrocarbon migration continues in the basin to the present day, as witnessed by the seepage of oil into Quaternary sands and peats at Formby, on the Lancashire coast.

In the 1990s, the Hamilton, Douglas, and Lennox fields, with a mixture of oil and gas, were discovered parallel with the North Wales coast in the southern part of the EISB (Fig. 6). Most of the deep wells of these fields encountered Millstone Grit Group below the Variscan Unconformity, as at Formby. Using isotopes the sampled oils (from 110/15-6, Lennox and 110/13-10, Douglas Oilfield) were correlated with each other, and the Holywell bitumen and the Holywell Shales (correlative of the Bowland Shale Formation) of NE Wales thereby proving the Bowland Shale source (Armstrong et al. 1997). These were isotopically lighter (more negative) than Westphalian cannel coals of Type I kerogen, for example those formerly mined and used to make oil at Leeswood in North Wales (Falcon \& Kent 1960). Waxy crude shows in the Millstone Grit Group in well 110/07b-6 (1510 m-1675 m; Released Geochemical Report) showed an isotopically similar source to shows in wells 110/07-2, 110/08-3 and Formby. The API of the Irish Sea oils range from 40-45 at Lennox and Douglas (Hardman et al. 1993), to 37 at Formby (Armstrong et al. 1997), perhaps suggesting a less mature source in the onshore field. Many additional small fields have been discovered subsequently, mostly in the centre of the EISB and mostly containing gas, culminating with the Rhyl discovery in 2009. In the Irish Sea, no significant Carboniferous reservoirs or good shows 
have been reported but there is at least one discovery (113/27-2) in the Collyhurst Sandstone (Appleby Group).

398

399

400

401

402

403

404

405

406

407

408

409

410

411

412

413

414

415

416

417

418

419

420

421

422

423

424

425

426

427

428

429

430

431

432

433

434

435

436

437

438

439

440

441

442

443

444

\section{Stratigraphy of the petroleum system}

Carboniferous source rocks are shown in Fig. 7, as covering the lower part of the Namurian and highest part of the Visean where shales are developed; Pennine Coal Measures may make a contribution where preserved. The lithostratigraphical terminology used here is that introduced by Waters et al. (2011) to better integrate the offshore with the onshore geology than previous schemes (e.g. Jackson et al. 1999). The Carboniferous source rocks are separated from the Triassic Ormskirk Sandstone reservoir rocks by the Millstone Grit Group and, where present, Pennine Coal Measures and Warwickshire groups. Above the Variscan Unconformity the Permian Appleby and Cumbrian Coast groups, and the lower, tight part of the Triassic Sherwood Sandstone Group, also intervene. A Pendleian time slice (Fig. 9) highlights the persistence of the relatively deep marine hemipelagic successions (Bowland Shale Formation) across the central part of the British Isles, including the Craven Basin, EISB and westward towards the Dublin Basin (Ramsbottom et al. 1969; Cope et al. 1992; Jackson \& Mulholland 1993; Wakefield et al. 2016). The late Pendleian saw the first major influx of thick fluvial and deltaic sandstones into the Craven Basin, both from the north and from the south. The northern basin fill are characterised by a thick pro-deltaic ramp turbidites, overlain by a siltstone-dominated slope succession, in turn overlain by a fluvio-deltaic, delta-top sandstone (Collinson 1988; Wakefield et al. 2016). The hemi-pelagic successions have gamma values which suggest potential as source rocks. The overlying successions of the Pennine Coal Measures and Millstone Grit groups have potential as a combined source-reservoir unit, with secondary sources from marine influxes and coaliferous sediments.

Clastic intervals within the Carboniferous and Permian successions that are evaluated for reservoir potential include the Appleby Group, Warwickshire Group, Pennine Coal Measures Group, Millstone Grit Group and Bowland Shale Formation. The Carboniferous Limestone Supergroup has been assessed as a potential reservoir, although the effect of secondary, karstified and fracture porosity has not been analysed. The preservation and thickness of the possible reservoir units is variable, particularly the Carboniferous units beneath the Variscan Unconformity (Fig. 6). Interpretation of well logs and associated core analyses (biostratigraphy, poroperm etc) frequently provide alternative stratigraphic interpretations to those shown on the well composite log, and have been carried out in this study (Fig. 9a, b). Many authors have referred to the problems in identification that results from secondary reddening of the Carboniferous strata below the Variscan Unconformity (Trotter 1954; Falcon \& Kent 1960; Jackson et al. 1995) in both the adjacent onshore and within the EISB. In the south of the basin, thick Appleby Group strata overlie the Variscan Unconformity and stratigraphic interpretation is straightforward. However, in the Morecambe fields area, the Appleby Group is absent and the Cumbrian Coast Group is interpreted to overlie the Variscan unconformity (Fig. 9b). This is important because it shows the probable topography of the Carboniferous surface, deformed and uplifted by the Variscan Orogeny, and the extent of erosion and eventual burial. The Cumbrian Coast Group comprises a varied sequence of thin sandstones, anhydrites, limestones, halites and mudstones, mostly red in colour. Underlying redbeds have therefore been interpreted either as a mudstone facies of the Appleby or as Warwickshire Group strata, on well composite logs. The favoured interpretation, combining all the seismic and well evidence, is that the red beds directly underlying the Cumbian Coast Group are secondarily reddened. They often include thin sandstones and high gamma shales and rarely contain coals, and are believed to be mostly of Namurian depositional age.

\section{Source rocks}

One of the key risks in the Palaeozoic of the greater Irish Sea province is the quality, extent and maturity of source rock intervals. Potential source rocks include coals of the Pennine Coal Measures (Westphalian) and upper Millstone Grit (Namurian) groups; shales of the Bowland Shale Formation and Millstone Grit Group (Pendleian and Arnsbergian); and older Visean shales (unproven by sample data), for example in the lower part of the Yoredale Group. Compilation of the Rock-Eval source rock geochemical data from released legacy reports revealed a small data set (264 samples), limiting the analysis which could be 
undertaken (Vane et al. 2016). Where penetrated, the Pennine Lower Coal Measures Formation, Millstone Grit Group and Bowland Shale Formation are mainly gas-prone strata with poor-fair remaining generative potential, and are mature to the gas window at the sampled intervals in Quadrants 110 and 113 (Vane et al. 2016). Some shales within the Millstone Grit Group have TOC values (Fig. 11f) and S1 hydrocarbon values (Fig. 11a) greater than the Bowland Shale Formation. Given the maturity levels, source rock potential in these wells is likely to have been depleted by hydrocarbon generation, or the original quality of these source rocks was poor to fair. The Cumbrian Coast Group, Appleby Group and Carboniferous Limestone Supergroup sampled in two wells in Quadrant 111 are oil to gas window mature, but have low Total Organic Carbon (TOC) and low residual hydrocarbon generative potential. Data is generally lacking to characterise kerogen types using a Van Krevelen plot, however data from well 110/02b-10 (Fig. 11b) suggests a kerogen mix between Type II and III for the Millstone Grit Group and Pennine Coal Measures. A similar mixed system can also be expected for the Bowland Shale Formation but with a higher proportion of Type II kerogens. The high TOC and widespread extent of the Bowland Shale Formation favour it as the primary source rock, at least in the southern part of the Irish Sea. The other potential sources are ranked as secondary to this.

\section{Hydrocarbon maturation and generation}

Vitrinite reflectance data (Fig. 11d) shows that the Bowland Shale source rocks in wells are mature for oil and gas generation (Corcoran \& Clayton 1999; Vane et al. 2016). EISB oils were considered to have been derived from the source in the range $0.75-0.85 \%$ Ro maturity, and the condensate from $>1.0 \%$ Ro (Armstrong et al. 1997). Given the structural complexity for the area of interest, a singular burial trend and maturity profile cannot be defined. Cowan et al. (1999) gave examples of varying thermal and burial history at the basin margins changing over tens of kilometres. Three wells show a correlation of maturity increase with depth within the $\mathrm{T}_{\max }$ dataset: 110/07b-6, 110/02b-10 and to a lesser extent 113/27-1, indicating progressive oil window into gas window maturity with depth. Some of the $\mathrm{T}_{\max }$ data indicate a wide spread of temperatures at the same depth, perhaps reflecting reworked and caved material in addition to in situ measurements or possibly due to $\mathrm{T}_{\max }$ suppression caused by variable kerogen and free oil composition (Fig. 11c). Onshore Isle of Man boreholes (Shellag, Ballavarkish, Black Marble Quarry; Fig, 5) show a similar range of $\mathrm{T}_{\max }$, albeit with few samples (Racey 1999).

\section{Basin modelling}

A lack of preserved post-Jurassic strata has resulted in a range of burial and thermal models for the EISB, for example Cenozoic uplift estimates ranging from $<1 \mathrm{~km}$ to up to $3 \mathrm{~km}$ (Cowan et al. 1999; Quirk et al. 1999 and references therein). In this study, well 110/07b-6 was chosen for burial and thermal modelling as it had the most complete geochemical profile and thick Carboniferous section (Gent 2016; Fig. 12). The well is situated on a minor Variscan structural high, and is considered reasonably representative of the more marginal areas of the basin. The burial model was matched to the measured vitrinite reflectance (VR) profile and the calculated VR profile (from $T_{\max }$ ) (Fig. 12). Using published studies (Cowan et al. 1999; Quirk et al. 1999) and seismo-tectonic interpretations from this study a $700 \mathrm{~m}$ uplift event in the late Carboniferous, followed by a minor $150 \mathrm{~m}$ uplift during development of the Late Cimmerian Unconformity, and a final $1100 \mathrm{~m}$ uplift and increase in palaeo-heatflow in the Cenozoic were included. The modelling shows that burial of the Bowland Shale Formation source rock in the Carboniferous resulted in the early-mid mature oil window being reached, before uplift and subsequent deeper burial in the early Cenozoic, just reaching main gas generation in the base of the drilled strata (Fig. 12). This is consistent with the oil shows documented in the well geochemical report (Geochem Laboratories Ltd 1988). Carboniferous trap formation, migration and generation were all likely to have occurred during the Variscan Orogeny. However, subsequent uplift would have almost certainly breached the traps. Migration and trap formation was renewed in the Mesozoic and Cenozoic, with any modern day hydrocarbon accumulations required to have survived the potential structural breach as a result of Cenozoic inversion. 
Migration of hydrocarbons into Triassic reservoirs and traps has clearly been successful as evidenced by the producing oil and gas fields of the EISB. Oil migration to the Triassic Hamilton fields may have occurred, vertically along faults, in Jurassic and Cretaceous times (Yaliz 1998; Haig et al. 1997; Yaliz \& Taylor 2003). This study has highlighted how these fields overlie the Môn-Deemster inversion belt described above (Fig. 6), the structures of which may have acted as first stage reservoirs, subsequently breached to allow migration into overlying Triassic traps, formed posthumously as late as Cenozoic time, on a template created by the Variscan inversion structures. In a similar way, the Millom, Dalton and Calder fields, lying close to the Keys Fault, and Lennox Field, close to the Formby Point Fault, are Cenozoic age traps formed posthumously on a template provided by the second phase of Variscan inversion structures. As the basin depocentre widened and new areas came into the oil window, additional hydrocarbons may have been generated and continued to migrate southward. The basin depocentre within the dismembered Eubonia Tilt-block entered the gas window and gas migrated into the Morecambe and other fields. This may have occurred both pre- and post-Late Cimmerian uplift/sea-level fall (Bushell 1986). In a conceptual Carboniferous petroleum system model, migration is away from the steadily deepening and expanding hydrocarbon kitchen towards the margins of the basin, where these strata fail by thinning and overlap. In the north the boundary is strongly faulted (Lagman, Eubonia and Lake District boundary faults).

Characteristics of potential reservoirs was based on legacy core plug-measured porosity and permeability data and continuous petrophysical interpretations for 8 wells (Hannis 2016). Net-to-gross, porosity and basic permeability estimates were calculated for each formation, summarised in Table 1. In general, the results illustrate fairly low net to gross values of less than 10\% (except in the Permian-aged Appleby Group where net-to-gross was 79\%), porosities (highest formation averages mostly around $10 \%$ but up to $19 \%$ in the Appleby Group) and mainly poor average permeabilities (highest formation averages mostly less than $10 \mathrm{mD}$ ). Further examination of the distribution of potentially higher permeabilities within the Millstone Grit sandstone intervals could be worthwhile (Table 1). The core plug measured porosity versus permeability data by formation is exhibited in Fig. 13.

The aeolian-dominated Permian Appleby Group strata that include the Collyhurst Sandstone are a prospective reservoir interval. The group as proven in well data is commonly defined by a basal breccia, overlain by a thick clean sequence of aeolian sandstones, culminating in an upper sequence of breccias (Wakefield et al. 2016). Based on 6 wells in Quadrant 110 in the depth range 1300-2400 m, maximum measured core porosity is $21 \%$ with a highest formation average in all wells of $13 \%$. Permeability is however poor, with a maximum measured permeability of $71.5 \mathrm{mD}$ (vertical, $\mathrm{k}_{\mathrm{v}}$ ), and a highest formation average of $0.8 \mathrm{mD}$ (horizontal, $\mathrm{k}_{\mathrm{h}}$ ) and $7.90 \mathrm{mD}$ (vertically). Petrophysical analysis has confirmed the group as being a sandstone-dominated interval with an average net-to-gross ratio of $79 \%$. Petrophysical porosity and permeability calculations match with the core-measured values, with the highest average porosity calculated at $19 \%$ and highest average permeability estimates of $6.89 \mathrm{mD}$, with some estimates in the 50$100 \mathrm{mD}$ range for several wells (Table 1 and Hannis 2016).

The Warwickshire Group is the equivalent of the Ketch and Boulton formations of the southern North Sea in Quadrant 53 and Quadrants 43-44 (Waters et al. 2011). Onshore, the Warwickshire Group of North Wales and Cheshire Basin comprises predominantly red, brown, purple-grey mudstones and sandstones and locally green-grey siltstones and mudstones with thin coals. However, potential reservoir sandstones can be locally significant. The amount of sandstone relative to mudstone and siltstones within constituent formations of the Warwickshire Group varies considerably. In West Cumbria, the Whitehaven Sandstone Formation, at least 280 m thick (Akhurst et al. 1997; Dean et al. 2011) is mainly a red to deep purple or purplish brown, cross-bedded, micaceous, medium- to coarse grained sandstone (Wakefield et al. 2016). The Halesowen Formation was productive in the small mined Coalport Tar Tunnel 'field' in Shropshire during the $18^{\text {th }}$ and early $19^{\text {th }}$ century (Smith et al. 2005). In the East Midlands, the Warwickshire Group has been documented to have better reservoir characteristics than productive older late 
Carboniferous strata, but was spatially confined to the synclines (BGS 1984; Pharaoh et al. 2011). Data from Quadrant 53 and the English Midlands shows that an average porosity of $16 \%$ is likely, with a permeability of several hundred $\mathrm{mD}$, although the bulk of the data was from above $600 \mathrm{~m}$ depth. Therefore investigation of the Warwickshire Group as a reservoir interval offshore was considered, though seismic mapping indicated a limited extent in the greater Irish Sea province (Fig. 6) and there are no well penetrations and therefore no reservoir data for the group. However, Bolsovian-Asturian (Westphalian CD) age strata are recorded in well 33/22-1 along strike in the Kish Bank Basin (Jenner 1981).

In the EISB, the Pennine Coal Measures Group comprises interbedded grey mudstone, siltstone and pale grey sandstone, commonly with mudstones containing marine fossils in the lower part of the lower and upper part of the middle subdivisions, and more numerous and thicker coal seams in the intervening interval. The group shows an overall blocky to erratic log response, with thick high gamma mudstone and siltstone intervals and relatively thin (3-15 m) low gamma sandstones. The sandstones show considerable variation in wireline log character, including 'boxcar' motifs in thick, distributary channel sandstones (Wakefield et al. 2016). Onshore, sandstones are also frequently encountered (e.g. Cefn Rock and Hollin Rock of NE Wales coalfields, Worsley Delf Rock, Prestwich Rock and Newton Rock of Lancashire Coalfield) and are approximate equivalents to the productive sandstones in basinward East Midlands fields (e.g. Oak Rock, Crawshaw Sandstone, Wingfield Flags). Based on five wells in Quadrants 110 and 113, in the depth range 1400-3050 m, maximum measured core porosity is $10 \%$ with a highest formation average in all wells of $6 \%$. Permeability is generally poor with a maximum measured horizontal permeability $\left(\mathrm{k}_{\mathrm{h}}\right)$ of $9.43 \mathrm{mD}$, and a highest formation average for $\mathrm{k}_{\mathrm{h}}$ of $1.07 \mathrm{mD}$. Petrophysical analysis of the Pennine Coal Measures Group provides a similar outlook, with an average net to gross of $9 \%$. Net intervals have reasonable porosities, with the highest average porosity at $11 \%$. Permeability is generally poor with the highest average permeability estimated at $0.8 \mathrm{mD}$. However, permeability up to $61 \mathrm{mD}$ was estimated in one well (110/02b-9; Table 1, Hannis 2016).

The Namurian-aged Millstone Grit Group comprises cyclic sequences of quartzo-feldspathic sandstone, grey mudstone, thin coal and prominent seatearths, resulting from deposition by repeated progradational deltas (Collinson 1988). Common marine bands are present and represent discrete flooding events (Waters \& Condon 2012). Thick reservoir intervals are uncommon, with initial turbidite lobes passing into delta-top deposits with thin sandstones typically contained within sheetfloods,overbank deposits and stacked channels. Onshore, and potentially offshore, thicker sandbodies (up to $50 \mathrm{~m}$ thick) occupy incised valleys (Waters \& Condon 2012; Wakefield et al. 2016). Jackson et al. (1997; Figure 6) identified a Kinderscoutian sandstone unit up to $90 \mathrm{~m}$ thick in the Liverpool Bay region (111/20-1), which can be correlated with wells farther north (112/30-1 and 113/27-2) although considerably reduced in thickness. Onshore, Millstone Grit sandstones are encountered in NE Wales (e.g. Cefn-y-Fedw, Gwespyr Sandstone, Aqueduct Grit), Lancashire (e.g. Fletcherbank Grit, Pendle Grit and Warley Wise Grit), and in producing East Midland fields (e.g. the Rempstone Oilfield). The Namurian (Marsdenian) depocentre extends from the Staffordshire Gulf, probably to Preston and thins to SW under the Cheshire Basin (Collinson et al. 1977; Smith et al. 1995). This pattern continues into the offshore of the EISB with Namurian absent at the Rhuddlan well on the North Wales coast (Figs. 5, 9b). Based on samples from four wells in Quadrants 110 and 113, at 1950-3550 m depth, maximum measured core porosity is $10 \%$ with a highest formation average in all wells of $6 \%$ (Table 1). Permeability is poor, the maximum measured was $0.37 \mathrm{mD}\left(\mathrm{k}_{\mathrm{h}}\right)$, and the highest formation averages for $\mathrm{k}_{\mathrm{h}}$ and $\mathrm{k}_{\mathrm{v}}$ were $0.04 \mathrm{mD}$ and $0.05 \mathrm{mD}$ respectively. Petrophysical analysis provides a more promising outlook for the group, although the average net-to-gross is $10 \%$. Net intervals have a reasonable porosity, the highest average porosity is $11 \%$. Permeability is poor with an average estimate of $0.2-2.1 \mathrm{mD}$, apart from one well 113/27-2, which shows an average of $367.7 \mathrm{mD}$ (Table 1). Further analysis of these sandstones could therefore be beneficial (Hannis 2016).

The Bowland Shale Formation is only examined in the wells 110/11-1 and 110/07b-6, however the formation broadly shows an upwards decrease in carbonate turbidites and an increase in siliciclastic sandstone turbidites (Wakefield et al. 2016). Potential thin reservoir sandstones may be present. Well $110 / 07 \mathrm{~b}-6$ encounters a total of $16 \mathrm{~m}$ of these sandstones, giving a net-to-gross of $3 \%$. (The other well 
examined, 113/27-2, contained no net intervals). No core samples were taken, but petrophysical interpretation revealed that the net intervals had porosities up to $23 \%$, although the average porosity was 7 $\%$. Permeability estimates appear poor with an average of $0.7 \mathrm{mD}$ and maximum of $16.2 \mathrm{mD}$ (Table 1 , Hannis 2016).

Carboniferous Limestone Supergroup sequences are interpreted to be widespread over the EISB and thus worthy of investigation as a reservoir. Petrophysical analysis of the limestones encountered in two wells (112/25a-1 and 111/25A-1) appear clean, but have too low matrix porosities (less than $5 \%$ ) to be considered as a reservoir (Table 1), but accumulations could be hosted in secondary porosity as a result of karstfication or fracturing. Onshore, the Hardstoft Oilfield in Derbyshire (Craig et al. 2013) produced from the top of the Carboniferous Limestone, but despite numerous shows, no further production was established from this reservoir in the East Midlands fields (Falcon \& Kent 1960). Karstified limestones such as those known from Anglesey (Walkden \& Davies 1983) and apron reefs like those which crop out at Castleton, Derbyshire might be present in the offshore. Seismic evidence for the possible presence of reefs towards the top of the ramp of the Eubonia Tilt-block in Quadrant 109 (Fig. 4a) was described above and indicated schematically in Fig. 4a. Waulsortian mud-mounds of pre-Asbian age may also be possible reservoirs. They are seen at outcrop in the south of the Isle of Man (Dickson et al. 1987) and in the Craven Basin. In the prolific Williston Basin of Canada, collapsed mud-mounds up to $100 \mathrm{~m}$ tall provide excellent porosity but were initially hard to identify on seismic data (Kupecz et al. 1996).

\section{Seal rocks}

The Cumbrian Coast Group, which includes the Manchester Marls (Fig. 7), provides the most extensive potential seal to Permian or Carboniferous rocks across the whole of the greater Irish Sea area. The unit consists of thick evaporites in the north and central East Irish Sea, thinning southward, passing laterally into dolomitic mudstones (Jackson \& Mulholland 1993; Wakefield et al. 2016), and is encountered in wells in surrounding sub-basins. This seal has been proven to trap hydrocarbons in the well 113/27-2, and sealing potential is proven in 112/25a-1, with minor gas shows in the tight Appleby Group. In the producing EISB fields, any Cumbrian Coast Group seals were breached as the fluids migrated out of the Carboniferous and Permian into the Triassic Ormskirk Sandstone reservoir (Colter 1997). Carboniferous intraformational mudstone seals have proved adequate in all the onshore fields of the East Midlands (Pharaoh et al. 2011), Cousland in Scotland (Hallett et al. 1985), various fields in the Silver Pit and Cleaver Bank basins of the southern North Sea and numerous fields in the Netherlands and Germany (Pletsch et al. 2010), and could be expected to work in Carboniferous basins of the Irish Sea.

\section{Hydrocarbon prospectivity of the Carboniferous basins outside the EISB}

Whilst basins of the greater Irish Sea province outside the EISB have extensive seismic coverage of variable quality, there are few wells. Data is therefore lacking to constrain their hydrocarbon systems and is heavily dependent on onshore analogues.

\section{Solway Basin}

The Permian - Jurassic Solway Basin, linked NE to the Carlisle Basin and SW to the Peel Basin is underlain by a Carboniferous basin of the same trend, an extension of the Northumberland Trough (Chadwick et al. 1995; Fig. 2). Two well penetrations (112/15-1 and 112/19-1) prove a Visean - Namurian Yoredale Group distinguished from the Carboniferous Limestone Supergroup by the presence of fewer carbonates (Fig. 7). The Yoredale Group sandstones, limestones and siltstones represent a fluviodeltaic depositional environment (see Wakefield et al. 2016) which is a northward lateral equivalent of the basinal Bowland Shale Formation, i.e. the Bowland Shale facies is not proven and may not be present. The presence of deltatop lacustrine facies is a possibility, but has not been demonstrated. In the onshore Cumberland Coalfield, the coals are gassy (Colter 1997), but the Pennine Coal Measures Group have not been penetrated offshore in the Solway Basin. Potential Carboniferous reservoir intervals include a relatively small area of 
Warwickshire Group on both sides of the Maryport Fault (Figs. 5a, 6) and the Fell Sandstone Formation in the main part of the basin.

\section{Peel Basin}

The Peel Basin is a Permian-Jurassic basin lying between the Isle of Man and Northern Ireland, underlain by a Carboniferous carbonate platform. Wells 111/25a-1 and 111/15-1 penetrated the Mississippian age Carboniferous Limestone Supergroup, in contrast to the time-equivalent Yoredale Group encountered in the along-strike, Solway Basin. The lack of a clastic, fluvio-deltaic system may enhance the likelihood of the Bowland Shale (source rock) equivalent being present in younger strata between 111/25a-1 and the Isle of Man coast, but there is no data to test this hypothesis. The seismic reflection data are generally of poor quality, but allow the presence of a small outlier of Namurian strata to NW of the Isle of Man. The Peel Basin may extend to the Carlingford Lough area near the Irish border, south of the Mourne Mountains (Fig. 2). BGS boreholes (in Quadrant 112, near the Irish coast) 73/65 and 73/67 are of probable Visean age and form a rim to the Lower Palaeozoic Longford-Down Massif. BGS borehole 71/43 near the Isle of Man coast was dated as Namurian. The data available preclude evidence of a working Palaeozoic petroleum system in the Peel Basin, a conclusion previously reached by both Newman (1999) and Quirk et al. (1999).

\section{North Channel Basin}

The North Channel Basin is a NW-trending Permo-Triassic basin complex lying between the Southern Uplands and the Longford-Down Massif of N Ireland (Quinn 2008) and forms the main rift through the massif. Two tilt-blocks, the E-dipping Portpatrick and W-dipping Larne sub-basins, recognised by Maddox et al. (1997), are separated by the Southern Upland Fault (Fig. 2). Several smaller basins lie parallel in Scotland (Stranraer, Lochmaben) and Ireland (Strangford Lough). In the Portpatrick Sub-basin, the underlying strata are possibly Devonian, although the seismic is poorly resolved because the only well (111/15-1) passed through a fault adjacent to the Southern Uplands, and did not prove a Carboniferous section. Data is lacking for the presence of source, reservoir and seal in this area (Maddox et al. 1997). Permo-Triassic and underlying Devonian and Carboniferous strata are present onshore in the Larne and Lough Neagh basins of N Ireland. Onshore in the Midland Valley of Scotland and in N Ireland a range of potential Carboniferous source rocks (coals, carbonaceous mudstones) and sandstone reservoir intervals are documented, though there is considerable spatial variability (Browne et al. 1999; Read et al. 2002; Underhill et al. 2008; Reay 2004; 2012). Onshore in N Ireland, a Carboniferous prospect was drilled by Infrastrata plc in Woodburn Forest in 2016, without success (website). Seismic interpretation offshore (Pharaoh et al. 2016a) has included a Carboniferous succession in the Larne Basin buried to $5000 \mathrm{~m}$ and with faulting and folding observed offering potential for structural traps. However the interpretation is poorly constrained by data, precluding detailed assessment of petroleum system elements.

Brief mention can be made of the Rathlin Trough, which lies outside the study area, and for which only limited seismic data, covering the offshore extension of the Machrihanish Coalfield, have been studied. The source rocks include coals and oil shales (Murlough Bay Formation) of early Carboniferous age which have excellent TOC and which are mostly in the oil window, with smaller areas in the gas window (Reay 2012). This sequence together with volcanic rocks invites comparison with the Lothian part of the Midland Valley of Scotland (Read et al. 2002). Drilling took place at Magilligan in the west of the basin and at Ballinlea in 2008. In the latter well, oil was produced from the Carrickmore Formation sandstones (Providence 2013) of the wide Visean subcrop (Smith 1985).

\section{Petroleum system knowns and risks}

The distribution of the principal Carboniferous source rock (Bowland Shale Formation) as inferred from the seismic interpretation is constrained by a few borehole penetrations in the EISB, but the absence of boreholes in the deepest part of the basin (Keys and Lagman basins) and onto the Manx-Furness Ridge means that the northern limit is poorly constrained. The nature of the transition to the Solway Firth and 
Northumberland basins, where boreholes prove time-equivalent Yoredale facies is therefore poorly known. The lack of any offshore well data requires analogy with the adjacent onshore Carboniferous. In the northern part of the EISB, the very deep burial of the source (now at $>7 \mathrm{~km}$ depth despite Cenozoic inversion) and the strong thermal impact from the Fleetwood Dyke means it is probably overmature, compatible with high $\mathrm{CO}_{2}$ and Nitrogen levels observed in Rhyl and neighbouring fields (Cowan, 1996; Centrica, pers. comm. 2015). Leakage of hydrocarbons in the Cenozoic following fault reactivation and degassing consequent upon regional uplift, are further risks throughout the region. Source rocks may also be present in the Clyde basins and adjacent North Channel Basin, but are unlikely to be present in the southern part of the latter, or beneath the Peel Basin. Attenuation of the Carboniferous sequence southwards towards the Welsh Massif (Fig. 4b, 9a) also increases the source risk in this direction. The paucity of data on the maturity of the source means that this parameter cannot be mapped in detail. Similarly, the reservoir porosity-permeability characteristics are poorly known over large parts of the region studied. The petrophysical analyses presented here suggest that the Carboniferous sandstones beneath the Morecambe fields have very poor porosity and permeability, confirming information provided by Centrica (pers. comm. 2015). This is no doubt a consequence of their deep burial, and processes such as platy-illite development and silica cementation which severely affect even the overlying Triassic formations (Colter 1989; Bushell 1986; Woodward \& Curtis 1987; Cowan 1991; Stuart 1993). The Carboniferous tight gas play may work if hydraulic fracturing can be applied, as is presently being attempted at Kirby Misperton (Cleveland Basin) and in the Ravenspurn Deep (southern North Sea). Extensive carbonate platforms surrounding the Isle of Man (Manx Platform) and off North Wales (Colwyn Platform) also have unknown poroperm characteristics. Until more is known about possible secondary porosity (following dedolomitisation) and fracture density, the reservoir properties of these areas are ranked as high risk.

The Mercia Mudstone Group is a proven caprock to Sherwood reservoirs and is present throughout the EISB but is absent across the margins of the basin complex. The potential seal of the Permian Cumbrian Coast Group sequence thins and fails in the same directions. In the EISB a relatively thick shale and evaporite (St Bees Evaporites, Cumbrian Coast Group) may be developed. The same is true in the Portpatrick and Larne basins, where several Triassic halites are present (Quirk et al. 1999; Quinn 2008).

Analysis of seismic data, integrated with well, core data etc, indicates that the marginal areas of the EISB hold the greatest potential for undiscovered hydrocarbon resources in the Carboniferous, although the geochemical, petrophysical and other essential data are scant. In general, the presence of an effective seal is considered to represent the biggest risk in the hydrocarbon system at the margins of the EISB. Yetto-find prospects are anticipated to be relatively small in volume and with shallow column heights supported by Carboniferous intra-formational seals. The most prospective parts of the region, outside the Triassic play, are considered to be:

- Thick Westphalian combined reservoir and source rock sequences preserved in the Eubonia Tiltblock in Quadrant 109 (Fig. 4a), located outside the main Permian-Mesozoic graben system and less affected by Cenozoic inversion. The presence and quality of seals form a major risk as the Cumbrian Coast Group seal is thin or absent and Carboniferous intraformational seals are required but untested. Based on the limited dataset available in adjacent basins, reservoir quality is also a significant risk.

- A belt of Variscan inversion structures (the Môn-Deemster Foldbelt; Fig. 4b) correlated with structures on the Formby Platform, and the onshore Ribbledale Foldbelt, from which hydrocarbons sourced by a thick Bowland Shale sequence have leaked into the overlying, Triassic-hosted Hamilton fields (block 110/13). The biggest risk here is whether reservoirs exist and remain unbreached at the pre-Permian level, and retain good poro-perm characteristics at depths of about $2500 \mathrm{~m}$. 
- A more speculative play lies in the extensive carbonate platform in Quadrant 109 and surrounding the Isle of Man (Fig. 4a), in Asbian reefal facies with enhanced secondary porosity. Here, source rock presence and migration pathways, reservoir properties and seal quality are major risks.

- The Ribble Estuary Inlier east of the Formby Point Fault (Figs. 5c, 6) may contain a working petroleum play. It lies adjacent to the deep Deemster Basin where there is a thick sequence of Upper Carboniferous sedimentary rocks preserved, and between the Formby and Lennox fields. Well 110/9-1, within the Deemster Basin was dry, but appears to have good porosity in the Ormskirk Sandstone though no shows. Fluorescence was recorded in the Appleby Group.

- A potential play exists sourced from the Bowland Shale Formation in the deep Godred Croven Basin drilled by 110/11-1 migrated into the Carboniferous reservoir on the faulted highs of its flanks. The Ormskirk Sandstone is very shallow in these locations but the Carboniferous strata might be securely sealed by the Cumbrian Coast Group.

\section{Discussion}

The pre-Permian structural synthesis presented here is speculative in view of the limited number of offshore well penetrations of Carboniferous strata. For example, further tectonic partitions may exist within the inferred Eubonia Tilt-block. It is possible, for example, that the eastern part of the structure (underlying the Keys and Tynwald basins of the EISB) may represent a separate tilt-block with a hinge in the Lake District Boundary Fault System, and a master controlling fault in the west (ancestral Keys system). The presence of such a basin, referred to as the Lancaster Fells Basin, was inferred by Cowan et al. (1999). However, the available evidence suggests that the NNW structural trend did not play a significant role until latest Carboniferous time, so that an ancestral Keys Fault is regarded an unlikely Visean structural element. The nature of the link between the structures of Quadrant 109 and onshore Lancashire has been much speculated on in the past (e.g. Ramsbottom et al. 1978). Jackson \& Mulholland (1993) recognised the Menai Strait-Pendle Line link, but preferred to link the Q109 Arch to the High Haume Anticline of the Furness Inlier, in the southern Lake District. This paper shows that the Ribblesdale Foldbelt does extend west of the Leyland Basin and Formby Point Fault (c.f. Jackson \& Mulholland 1993; Figure 4 and p797) and links to the Q109 Arch, via the Môn-Deemster Foldbelt. More detailed seismic mapping of the Upper Carboniferous interval will be required to elucidate what is probably an intricately folded subcrop pattern here. We support the proposed continuity of the Bowland Basin southwestwards into the offshore area, as inferred by Corfield et al. (1996) and Cowan et al. (1999). From the perspective of hydrocarbon prospectivity, the presence of the prolific Bowland Shale Formation source rock interpreted across much of the EISB has been a key element in the hydrocarbon system of the overlying Permian to Mesozoic basins. Prospective reservoir intervals with moderate porosity are likely to exist in the Warwickshire Group and Pennine Coal Measures Group in the marginal parts of the EISB, although the permeability is likely to be poor. The EISB lay to west (Fig. 8) of the main Pennine deltaic and fluviatile fairway in the onshore (Fraser et al. 1990), and consequently shows a lower net/gross sand ratio. Evidence from geophysical logs indicates that the EISB was less influenced by the repeated deltaic incursion so evident onshore, and a sharp transition between deltaic and basinal shale facies, of the type seen at Mam Tor and Edale, is neither observed nor to be expected there.

In a review of the deep reflection seismic data for the Irish Sea, principally BIRPS' WINCH lines and some deep data from JEBCO, England \& Soper (1997) state that from this limited dataset, there is no clear evidence for reactivation of earlier structures during either Carboniferous sedimentation or Variscan inversion. Using the exploration seismic data, this study describes the presence of fold-thrust structures in the pre-Carboniferous basement and, in the Môn-Deemster Foldbelt, demonstrates their role in controlling both Carboniferous extensional and inversion structures. The interpretation presented supports the view of England \& Soper (op. cit.) that the faults controlling Permian and Mesozoic basin development are 
discordant to the Caledonian, Acadian and early Carboniferous structural grain (as exemplified by the Q109 structures), and are therefore juvenile structures developed in late Westphalian to early Stephanian time. Evidence presented here suggests that these were initiated as a result of a late phase of Variscan inversion, reflecting W-E Uralide compression, superimposed on an earlier phase produced by N-S compression. The timing of these two inversion phases is imprecisely defined in the Irish Sea due to the significant missing stratigraphic section. However, in late Variscide intramontane basins in central France, N-S compression in Stephanian B time is followed by inferred phases of compression on NW-SE (late Stephanian B) and WE (mid-Stephanian C) principal stress axes (Gélard et al. 1986), the 'Bourbonnaise Phase' of Grolier (1971). Although interpreted in terms of systematic rotation of the principal horizontal compressive stress axis (Gélard et al. 1986; Blès et al. 1989; Ziegler 1990), Faure (1995) considered these deformations a consequence of late Variscan orogenic collapse. In the UK region, other manifestations of the late W-E compressive phase may include the W-E oriented basaltic dykes, and a component of growth of N-S trending folds, within the Midland Valley of Scotland (Monaghan \& Pringle 2004; Timmerman 2004); and W-E directed transport of fold nappes on the eastern margin of the Worcester Graben (Peace \& Besly, 1997).

The observed variation in Variscan structural orientation in the Variscan Foreland of Britain is currently explained in terms either of one resolved compressional vector (Corfield et al. 1996), or of strainpartitioning across a heterogeneous basement template (e.g. De Paola et al. 2005). In the Irish Sea, it is difficult to argue for a strong control by a N-S oriented basement grain, as identified, for example, within the Midlands Microcraton (Corfield et al. 1996), and the presence of two discrete late Variscan deformation phases is regarded as a more likely scenario. Another expression of the multiple inversion history, and very significant for the formation of Ormskirk traps in the cover, is the impact of posthumous folding. This process, first recognised and described by Suess (1904), is very clearly demonstrated in the Irish Sea, where a template of Variscan inversion anticlines in the Carboniferous sequence underlies structures with similar trend but lower amplitude in the Permo-Triassic cover.

\section{Conclusions}

The study has demonstrated that the basins of the Irish Sea preserve a Phanerozoic geological history as complex as that of the UK onshore. A strong SW-NE structural grain was imprinted on the crust during late Precambrian and Caledonian accretion and orogenic deformation. Dipping zones of strong reflectivity in seismic sections are interpreted as major thrusts and shear zones, some of which can be correlated with known examples onshore. Mississippian rifting on SW-NE trending faults resulted in depocentres which accumulated marine shale source rocks, preceding regional thermal subsidence. The Eubonia Tilt-block is a major Carboniferous syndepositional element beneath the northern part of the EISB, but was partially dismembered by the formation of the ancestral Keys Fault system. The Eubonia-Lagman fault system formed the syndepositional bounding fault to the tilt-block. The Bowland Shale Formation forms the main source rock interval, with inferred thickest development likely within the Môn-Deemster Foldbelt, the offshore correlative of the Bowland Basin, and its inversion, the Ribblesdale Foldbelt. This source rock is buried to depths $>7 \mathrm{~km}$ under the Lagman and Keys basins and is probably post-mature there at the present day.

The Millstone Grit Group and Bowland Shale Formation contain thin clean sandstones locally up to $90 \mathrm{~m}$ thick which could be considered potential reservoirs. Prospective areas at these stratigraphic levels may exist at depth adjacent to the Keys Basin, and west of the Keys Fault. The Millstone Grit Group also has the potential to act as a secondary source rock, as do the Pennine Coal Measures Group when buried deep enough to achieve maturity. However, the latter were stripped from a large area of the EISB following Variscan inversion. Pennsylvanian strata exhibit marked thinning to the south onto the Conwy Platform. Burial by Upper Carboniferous sediments likely resulted in early maturation of kerogen in source rocks within the deepest basins, but destruction of reservoir porosity and permeability in the depocentres. 
Warwickshire Group sedimentary rocks were not so deeply buried, and are likely to retain better reservoir characteristics.

The Variscan Orogeny, in late Carboniferous time, caused uplift, folding and thrusting on both WSW-ENE (Môn-Deemster) and NNW-SSE to N-S (Keys-Gogarth) trends, probably in two phases, corresponding to well-documented main compressional phases of the Variscan-Uralian Orogen. The later inversion phase occurred on NNW-SSE to N-S trending zones of deformation which would subsequently become localised as the main synsedimentary bounding faults of the EISB in Permian to Mesozoic time. Corfield et al. (1996) provided a definition of inversion intensity. In the greater Irish Sea region, the intensity ranges from moderate (in the EISB, Solway and Clyde basins) to strong, with almost complete removal of the post-rift fill (in the North Channel basins and Peel Basin). The timing of these events is poorly constrained in the Irish Sea due to significant missing stratigraphic section, but by comparison with intramontane basins in France, is likely of intra-Stephanian age. The Variscan inversion structures have not yet been adequately tested as targets. They form both first-stage hydrocarbon reservoirs and the structural template for more gentle, 'posthumous' folds produced by Alpine inversion which form traps in the Triassic cover (e.g. the Hamilton fields). Deposition of Permian Appleby Group and Cumbrian Coast Group strata resulted in a potential reservoir - seal combination overlying the Carboniferous source rocks. Permian to Mesozoic rifting is along NNW-SSE and N-S trends. These faults cut discordantly across the early Carboniferous structures and have allowed late Cretaceous to early Cenozoic vertical migration of Carboniferous-sourced hydrocarbons into Triassic reservoirs. There is a migration route to Triassic reservoirs in the centre of the EISB because the Warwickshire Group and Appleby Group strata have been removed from that area, and the thin Cumbrian Coast Group seal breached, where the producing hydrocarbon fields are located. The Clyde-North Channel basin complex, Solway and Peel basins also contain Devonian and/or Carboniferous rocks beneath Permo-Triassic strata, but have likely been buried less deeply than those in the EISB. The North Channel basins may also have suffered significant Variscan inversion. Extensive 2D seismic datasets cover the latter areas but there are only four well penetrations. There have been no discoveries, interpreted to be largely a consequence of the absence of a regional seal comparable in quality to the Mercia Mudstone Group in the EISB. The prolific Bowland Shale source is also absent in these basins, being replaced by fluvio-deltaic sedimentation of the Yoredale Group. Very limited well penetrations do not presently allow a realistic assessment of the prospectivity of the Carboniferous strata underlying these poorly drilled basins.

\section{(Acknowledgements)}

This work was undertaken as a joint-industry project for the former Department of Energy and Climate Change (DECC) now Oil and Gas Authority (OGA), Oil and Gas UK and 49 oil and gas company sponsors as part of the 21CXRM (21 ${ }^{\text {st }}$ Century Exploration Roadmap) Palaeozoic Project. Thanks to Richard Milton-Worsell for his enthusiastic guidance and to the Technical Steering Committee of the project. The role of CGG Geospec, IHS and Western-Geco in supplying regional speculative data for this study is gratefully acknowledged, likewise the provision of data from the CDA and UKOGL data libraries. The staff of Centrica plc are thanked for very helpful and productive discussions. The assistance of the CCS team at BGS, in particular John Williams, in pre-conditioning the well database, was of great help. Mike Sankey is thanked for supplying seismic data from the DECC-OGA digital datastore. Keith Henderson and Sandy Henderson improved the quality of many of the diagrams. Finally, we acknowledge the contribution of the reviewers (Ian Andrews and two anonymous referees) and publication editor (John Underhill) in improving the manuscript. This paper is published with the permission of the Executive Director, British Geological Survey. 
AKhUrst, M.C., Chadwick, R.A., Holliday, D.W., McCormaC, M., McMillan, A.A., Millward, D. \& Young, B. 1997. Geology of the west Cumbria district. Memoir of the British Geological Survey, Sheets 28, 37 and 47 (England \& Wales). (London: HMSO).

ANDREWS, I. J. 2013. The Carboniferous Bowland Shale gas study: geology and resource estimation. British Geological Survey for Department of Energy and Climate Change, London, UK

Armstrong, J. P., Smith, J., D'elia, V. A. A. \& Trueblood, S. P. 1997. The occurrence and correlation of oils and Namurian source rocks in the Liverpool Bay-North Wales area. In: Meadows, N. S., Trueblood, S. P., Hardman, M. \& Cowan, G. (eds.) Petroleum Geology of the East Irish Sea and Adjacent Areas. Geological Society, London, Special Publications, 124, 195-211.

ARTER, G. \& FAGIN, S. W. 1993. The Fleetwood Dyke and the Tynwald fault zone, Block 113/27, East Irish Sea Basin. In: PARKER, J. R. (ed.) Petroleum geology of Northwest Europe: Proceedings of the 4th Conference. The Geological Society, London, 835-843.

Barclay, W.J., Ambrose, K., CHADWICK, R.A., \& PharaOH, T.C. 1997. Geology of the country around Worcester. Memoir of the British Geological Survey, Sheet 199 (England and Wales) (London: HMSO).

Barnes, R.P., Branney, M.J., Stone, P. \& Woodcock, N.H. 2006. The Lakesman Terrane: the Lower Palaeozoic record of the deep marine Lakesman Basin, a volcanic arc and foreland basin. In: BRENCHLEY, P.J. \& RAWSON, P.F. (eds) 2006. The Geology of England and Wales. Second Edition. Geological Society, London, 103-129.

BADLEY, M.E., PRICE, J.D., \& BACKSHALL, L.C. 1989. Inversion, reactivated faults and related structures: seismic examples from the southern North Sea. In: COOPER, M.A., \&WILLIAMS, G.D. (eds.). Inversion Tectonics. Geological Society, London, Special Publications, 44, 201219.

BESLY, B. M. 1988. Palaeogeographic implications of late Westphalian to early Permian red-beds. In: BESLY, B. \& KELLING, G. (eds.). Sedimentation in a synorogenic basin complex: the Upper Carboniferous of northwest Europe. Blackie, Glasgow and London, 200-221.

Besly, B. M. 1998. Carboniferous. In: GLENNIE, K. W. (ed.). Petroleum Geology of the North Sea: Basic concepts and recent advances. Blackwell Science Ltd, Oxford, 104-136.

BlÈs, J. L., BONIJOly, D., CASTAing, C., \& GROS, Y., 1989. Successive post-Variscan stress fields in the European plate (Massif Central and its borders): comparison with geodynamic data. Tectonophysics, 169, 79-111.

BLOw, R. A. \& HARDMAN, M. 1997. Calder field appraisal 110/7a-8, East Irish Sea Basin. In: Meadows, N. S., Trueblood, S. P., Hardman, M. \& Cowan, G. (eds.). Petroleum geology of the Irish Sea and adjacent areas. Geological Society, London, Special Publications, 124, 387-397.

Bluck, B.J., 2002. The Midland Valley Terrane. In: Trewin, N.H. (ed). Geology of Scotland. Fourth Edition. Geological Society, London, 149-166. 
BoniJoly, D. \& CASTAING, C. 1984. Fracturation et genèse des bassins stéphaniens du Massif Central français en regime compressif. Annales Société géologique du Nord, Lille, CIII, 187199.

BRITISH GEOLOGICAL SURVEY (BGS). 1994. East Midlands Hydrocarbon Prospectivity Report Confidential for DTI .

British Geological SurVey (BGS). 1994. East Irish Sea. Special Sheet Edition. Solid Geology.1:250 000. (Edinburgh, Scotland: British Geological Survey)

BRODIE, J., \& White, N. 1994. Sedimentary basin inversion caused by igneous underplating: northwest European continental shelf. Geology, 22, 147-150.

Brown, D., Juhlin, C. \& PuchKov, V. 2002. (Eds.). Mountain Building in the Uralides: Pangea to the Present. Geophysical Monograph 132. (Washington DC: American Geophysical Union). 286pp.

Browne, M. A. E., DeAn, M. T., Hall, I. H. S., McAdam, A. D., Monro, S. K., \& Chisholm, J. I. 1999. A lithostratigraphical framework for the Carboniferous rocks of the Midland Valley of Scotland. British Geological Survey, Research Report, RR/99/07.

Bushell, T. P. 1986. Reservoir geology of the Morecambe Field. In: BROOKS, J., GoFF, J. C. AND VAN HoORN, B. (eds.). Habitat of Palaeozoic gas in NW Europe. Geological Society, London, Special Publications, 23, 189-208.

CALVER, M.A, 1968. The distribution of Westphalian marine faunas in northern England and adjoining areas. Proceedings of the Yorkshire Geological Society, 44, 479-496.

CHADWICK, R.A.1993. Aspects of basin inversion in southern Britain. Journal of the Geological Society of London, 150, 311-322.

CHADwICK, R. A. 1997. Fault analysis of the Cheshire Basin, NW England. In: MeAdows, N. S., Trueblood, S., Hardman, M., \& Cowan, G. (eds.). Petroleum geology of the Irish Sea and adjacent areas. Geological Society, London, Special Publications, 124, 297-313.

Chadwick, R. A. \& Evans, D. J. 1995. The timing and direction of Permo-Triassic extension in southern Britain. In: Boldy, S. A.R., \& HARDMAn, R.F.P.(eds.). Permian and Triassic rifting in NW Europe. Geological Society, London, Special Publications, 91, 161-192.

Chadwick, R. A., Evans, D. J. \& Holliday, D. W. 1993. The Maryport Fault: the post-Caledonian tectonic history of southern Britain in microcosm. Journal of the Geological Society of London, 150, 247-250.

Chadwick, R.A., Holliday, D.W., Holloway, S. \& Hulbert, A.G. 1995. The NorthumberlandSolway basin and adjacent areas. Subsurface memoir of the British Geological Survey.

CHADWICK, R.A., JACKSON, D.I., BARnES, R.P., Kimbell, G.S., JOHNSON, H., CHIVERRELl, R.C., Thomas, G.S.P., Jones, N.S., Riley, N.J., Pickett, E.A., Young, B., Holliday, D.W., Ball, D.F., MolyneuX, S.G., LONG, D,. Power, G.M., \& RoberTs, D.H. 2001. The geology of the Isle of Man and its offshore area. British Geological Survey Research Report, RR/01/06.

Chew, D.M. \& Strachan, R.A. 2014. The Laurentian Caledonides of Scotland and Ireland. In: Corfu, F., GAsser, D.Q. \& ChEw, D.M. (eds). New perspectives of the Caledonides of Scandinavia and Related Areas. Geological Society, London, Special Publications, 390, 45-91. 
Collinson, J. 1988. Controls on Namurian sedimentation in the Central Province basins of northern England. In: BESLY, B. \& KelLING, G. Sedimentation in a synorogenic basin complex: the Upper Carboniferous of northwest Europe. Blackie, Glasgow and London, 200-221.

COLTER, V. S. \& BARR, K.W. 1975. Recent developments in the geology of the Irish Sea and Cheshire basins. In: WoOdLAND, A.W. (ed.). Petroleum and the Continental Shelf of North West Europe. Volume 1: Geology. Applied Science Publishers, London, 61-75.

COLTER, V. S. 1997. The East Irish Sea Basin - from caterpillar to butterfly, a thirty-year metamorphosis. In: Meadows, N.S., Trueblood, S.P., Hardman, M. \& Cowan, G. (eds.), Petroleum Geology of the Irish Sea and Adjacent Areas. Geological Society, London, Special Publications, 124, 1-10.

COPE, J. C. W. 1994. A latest Cretaceous hotspot and the southeasterly tilt of Britain. Journal of the Geological Society of London, 151, 905-908.

COPE, J. C. W. 1997. The Mesozoic and Tertiary history of the Irish Sea. In: MEAdows, N S, Trueblood, S. P., Hardman, M., \& Cowan, G. (eds.). Petroleum geology of the Irish Sea and adjacent areas. Geological Society, London, Special Publications, 124, 47-59.

CoPe, J.C.W., INGHAM, J.K. \& RAWSON, P.F. 1992. Atlas of palaeogeography and lithofacies. Geological Society, London, Memoir, 13.

CORCORAN, D. \& ClAYTON, G. 1999. Interpretation of vitrinite reflectance profiles in the Central Irish Sea area: implications for the timing of organic maturation. Journal of Petroleum Geology, 22, 261-286.

Corfield, S.M., Gawthorpe, R.L., Gage, M., Fraser, A.J. \& Besly, B.M. 1996. Inversion tectonics of the Variscan foreland of the British Isles. Journal of the Geological Society, London, 153, 17-32.

CowAn, G. 1996. The development of the North Morecambe Gas Field. Petroleum Geoscience 2, 4352.

COWAN, G. \& BRADNEY, J. 1997. Regional diagenetic controls on reservoir properties in the Millom accumulation: implications for field development. In: MEADOWS, N.S., TRUEBLOOD, S.P., Hardman, M. \& Cowan, G. (eds.), Petroleum Geology of the Irish Sea and Adjacent Areas. Geological Society, London, Special Publications, 124, 373-386.

Cowan, G., Burley, S., Hoey, N., Holloway, P., Bermingham, P., Beveridge, N., Hamborg, M., \& SYLTA, Ø., 1999. Oil and gas migration in the Sherwood Sandstone of the East Irish Sea Basin. In: FLEET, A. J. \& BOLDY, S. A. R. (eds.) Petroleum Geology of northwest Europe: Proceedings of the 5th Conference, Geological Society, London, 383-398.

COWARD, M. P. 1993. The effect of Late Caledonian and Variscan continental escape tectonics on basement structure, Paleozoic basin kinematics and subsequent Mesozoic basin development in NW Europe. In: PARKER, J. R. (ed.) Petroleum geology of Northwest Europe: Proceedings of the 4th Conference. The Geological Society, London, 1095-1108.

COWARD, M. P. 1995. Structural and tectonic setting of the Permo-Triassic basins of northwest Europe. In: Boldy, S. A. R., \& HARDMAN, R. F. P. (eds.). Permian and Triassic rifting in northwest Europe. Geological Society, London, Special Publications, 91, 7-40. 
Craig, J., GluYas, J., LAING, C. \& SchOFIElD, P. 2013. Hardstoft - Britain's First Oil Field. Oil Industry History, 14, 97-116.

De PaOla, N., Holdsworth, R. E., McCaffrey, K. J., \& BarChi, M. R. 2005. Partitioned transtension: an alternative to basin inversion models. Journal of Structural Geology, 27, 607625 .

Dean, M. T., Browne, M. A. E., WAters, C. N., \& Powell, J. H. 2011. A lithostratigraphical framework for the Carboniferous successions of northern Great Britain (onshore) British Geological Survey Research Report, RR/10/07, 165pp.

DICKSON, J. A. D, FORD, T. D., \& SWIFT, A. 1987. The stratigraphy of the Carboniferous rocks around Castletown, Isle of Man. Proceedings of the Yorkshire Geological Society, 46, 203229.

EASTWOOD, T., DiXON, E.E.L., HOLLINGWORTH, S.E. \& SMITH, B. 1931. The geology of the. Whitehaven and Workington district. Memoir of the Geological Survey of Great Britain, Sheet 28 (England \& Wales).

ENGLAND, R. W. \& SOPER, N.J. 1997. Lower crustal structure of the East Irish Sea from deep seismic reflection data. In: MEADOWS, N.S., TRUEBLOOD, S.P., HARDMAN, M. \& COWAN, G. (eds.), Petroleum Geology of the Irish Sea and Adjacent Areas. Geological Society, London, Special Publications, 124, 61-72.

FALCON, N. L. \& KENT, P. E. 1960. Geological results of petroleum exploration in Britain 19451957. Geological Society, London, Memoir 2.

FAURE, M. 1995. Late orogenic Carboniferous extensions in the Variscan French Massif Central. Tectonics, 14, 132-153.

Floodpage, J., Newman, P. \& White, J. 2001. Hydrocarbon prospectivity in the Irish Sea area: insights from recent exploration of the Central Irish Sea, Peel and Solway basins. In: Shannon, P. M., Haughton, P. D. W. \& Corcoran, D. V. (eds.). The Petroleum Exploration of Ireland's Offshore Basins. Geological Society, London, Special Publications, 188, 107-134.

FraSER, A. J. \& GAWTHORPE, R. L. 2003. An atlas of Carboniferous basin evolution in northern England. Geological Society, London, Memoir 28.

Fraser, A. J., NASH, D. F., STEELE, R. P. \& EBDON, C.C. 1990. A regional assessment of the intraCarboniferous play of northern England. In: BROOKS, J. (ed.). Classic Petroleum Provinces. Geological Society, London, Special Publications, 50, 417-440.

GÉlard, J. -P., CASTAing, C., BoniJoly, D., \& GRolier, J. 1986. Structure et dynamique de quelques bassins houlliers limniques du Massif Central. Memoire Société Géologique de France, 149,576-72.

GENT, C. M. A. 2016. Maturity modelling of well 110/07b-6. British Geological Survey Commissioned Report, CR/16/043. http://nora.nerc.ac.uk/id/eprint/516793

GEOCHEM LABORATORIES LIMITED, 1988. Prepared for Kelt UK Ltd, London. Geochemical Evaluation and Correlation Study Morecambe Bay 110/7b-6 Well. (110_07b_6_rep_GEOL_CHEM_105249616.pdf released on CDA). 
GIBBONS, W. 1987. The Menai Strait fault system: an early Caledonian terrane boundary in North Wales. Geology 15, 744-747.

GILES, M.R., \& INDRELID, S.L. 1998. Divining burial and thermal histories from indicator data: application and limitations. In: VAN Den HAUte, P. \& De Corte, F. (eds.) Advances in Fission Track Geochronology. Kluwer Academic Publishers, Dordrecht, 115-150.

GREEN, P. F., DUDDY, I. R. \& BRAY, R. J. 1997. Variation in thermal history styles around the Irish Sea and adjacent areas: implications for hydrocarbon occurrence and tectonic evolution. In: Meadows. N., Trueblood, S., Hardman, M. \& Cowan, G. (eds.). Petroleum Geology of the Irish Sea and Adjacent Areas. Geological Society, London, Special Publications, 124, 73 93.

GROLIER, J. 1971. Le tectonique du socle hercynien dans le Massif Central. In: JUNG, J. (Ed.). Symposium.: Géologie, géomorphologie et structure profonde du Massif Central français. (Clermont-Ferrand: Plein Air Service), 215-260.

Haig, D.B., Pickering, S.C. \& Probert, R. 1997. The Lennox oil and gas Field. In: Meadows, N.S., Trueblood, S.P., Hardman, M. \& Cowan, G. (eds.). Petroleum Geology of the Irish Sea and Adjacent Areas. Geological Society, London, Special Publications, 124, 417-436.

Hallett, D., DURANT, G.P. \& FARROW, G.E. 1985. Oil exploration and production in Scotland. Scottish Journal of Geology, 21, 547-570.

HANNIS, S. 2016. Reservoir evaluation of 8 wells in the Palaeozoic of the Irish Sea: Petrophysical interpretations of clay volume, porosity and permeability estimations. British Geological Survey Commissioned Report, CR/16/042. http://nora.nerc.ac.uk/516774/

Hardman, M., Buchanan, J., Herrington, P. \& CARR, A. 1993. Geochemical modelling of the East Irish Sea Basin: its influence on predicting hydrocarbon type and quality. In: PARKER, J. R. (ed.). Petroleum Geology of Northwest Europe: Proceedings of the 4th Conference, Geological Society, London, 809-821.

HiLliER, R.D. \& WiLliams, B.P.J. 2006. The alluvial Old Red Sandstone: fluvial basins. Chapter 8 Geological Society, London, 809-821.In: BRENCHLEY, P.J. \& RAWSON, P.F. (eds.) 2006. The Geology of England and Wales. Second Edition. Geological Society, London, 103-129.

JACKSON, D.I., JACKSON, A.A., Evans, D., WIngFiElD, R.T.R., BARNES, R.P. \& ARTHUR, M.J. 1995. United Kingdom offshore regional report: the geology of the Irish Sea. HMSO, London.

JACKSON, D.I. \& JOHNSON, H. 1996. Lithostratigraphic nomenclature of the Triassic, Permian and Carboniferous of the UK offshore East Irish Sea Basin. (Nottingham: British Geological Survey).

JACKSON, D.I., JOHNSON, H. \& SMITH, N.J.P. 1997. Stratigraphical relationships and a revised lithostratigraphical nomenclature for the Carboniferous, Permian and Triassic rocks of the offshore East Irish Sea Basin. In: Meadows, N.S., Trueblood, S.P., Hardman, M. \& CowAn, G. (eds.), Petroleum Geology of the Irish Sea and Adjacent Areas. Geological Society, London, Special Publications, 124, 11-32.

JACKSON, D.I., JONES, N.S., \& WATERS, C.N. 2011. Chapter 16: Irish Sea (including Kish Bank). In: Waters, C.N., Somerville, I.D., Jones, N.S., Cleal, C.J., Collinson, J.D., Waters, R.A., Besly, B.M., DeAn, M.T., Stephenson, M.H., DAVIES, J.R., Freshney, E.C., JaCKSON, D.I., Mitchell, W.I., POWEll, J.H., BARClay, W.J., Browne, M.A.E., 
LEVERIDGE, B.E., LONG, S.L., \& MCLEAN, D. (eds). A Revised Correlation of Carboniferous Rocks in the British Isles. Geological Society, London, Special Reports, 26, 110-116.

JACKSON, D I, \& MULhOlLAND, P. 1993. Tectonic and stratigraphical aspects of the East Irish Sea Basin and adjacent areas: contrasts in their post-Carboniferous structural styles. In: PARKER, J $\mathrm{R}$ (ed.). Petroleum geology of northwest Europe: Proceedings of the 4th Conference. Geological Society, London, 791-808.

JACKSON, D.I., Mulholland, P., Jones, S.M. \& WARRINGTON, G. 1987. The geological framework of the East Irish Sea Basin. In: Brooks J. \& GLenNIE, K. (ed.) Petroleum Geology of North West Europe, 191-203. Graham and Trotman, London.

JENNER, J.K. 1981. The structure and stratigraphy of the Kish Bank Basin. In: Illing, L.V. \& Hobson, G.D. (eds). Petroleum Geology of the Continental Shelf of North West Europe. Heyden, London.

Jones, N. S., HollidAY, D. W. \& McKerVeY, J. A. 2011. Warwickshire Group (Pennsylvanian) redbeds of the Canonbie Coalfield, England-Scotland border, and their regional palaeogeographical implications. Geological Magazine, 148, 50-77

KENT, P. E. 1978. Subsidence and uplift in East Yorkshire and Lincolnshire: a double inversion. Proceedings of the Yorkshire Geological Society, 42, 505-524.

KENT, P. E. 1985. UK onshore oil exploration, 1930-1964. Marine and Petroleum Geology, 2, 56-64.

KIMBELL, G. S. \& QUIRK, D. G. 1999. Crustal magnetic structure of the Irish Sea region: evidence for a major basement boundary beneath the Isle of Man. 227-238. In: WOODCOCK, N. H., QUIRK, D. G., FITCHES, W. R. \& BARNES, R. P. (eds.). In sight of the suture: the geology of the Isle of Man in its Iapetus Ocean context. Geological Society, London, Special Publications, 160, 227-238.

Kirby, G. A., Baily, H. E., Chadwick, R. A., Evans, D. J., Holliday, D. W., Holloway, S., Hulbert, A. G., Pharaoh, T. C., SMith, N. J. P., AitKenhead, N. \& Birch, B. 2000. The structure and evolution of the Craven Basin and adjacent areas. Subsurface Memoir of the British Geological Survey. (Keyworth, Nottingham: British Geological Survey.) 130pp.

KIRTON, S. R. \& DONATO, J. A. 1985. Some buried Tertiary dykes of Britain and surrounding waters deduced by magnetic modelling and seismic reflection methods. Journal of the Geological Society of London, 142, 1047-1057.

KNIPE, R. J., COWAN, G., \& BALENDRAN, V. S. 1993. The tectonic history of the East Irish Sea Basin with reference to the Morecambe Fields. In: PARKER, J. R. (ed.). Petroleum geology of northwest Europe: Proceedings of the 4th Conference. Geological Society, London, 857-866.

KuPECZ, J.A., ARESTAD, J.F. \& BLOTT, J.E. 1996. Integrated study of Mississippian Lodgepole Waulsortian Mounds, Williston Basin, USA. Society of Exploration Geophysicists, SEG-19960401 .

LEEDER, M. R. 1982. Upper Palaeozoic basins of the British Isles - Caledonide inheritance versus Hercynian plate margin processes. Journal of the Geological Society of London, 139, 479-491.

Leslie, A.G., Millward, D., Pharaoh, T., Monaghan, A.A., Aresenikos, S., \& Quinn, M. 2015. Tectonic synthesis and contextual setting for the Central North Sea and adjacent onshore areas, 
21CXRM Palaeozoic Project. British Geological Survey Commissioned Report, CR/15/125. 18pp. http://nora.nerc.ac.uk/516757/

MADDOX, S.J., BLOW, R.A. \& O'BRIEN, S.R. 1997. The Geology and hydrocarbon prospectivity of the North Channel Basin. In: Meadows, N.S., Trueblood, S.P., Hardman, M. \& Cowan, G. (eds.), Petroleum Geology of the Irish Sea and Adjacent Areas. Geological Society, London, Special Publications, 124, 95-111.

Meadows, N.S., Trueblood, S.P., Hardman, M. \& Cowan, G. 1997. (eds.), Petroleum Geology of the Irish Sea and Adjacent Areas. Geological Society, London, Special Publications, 124, $447 \mathrm{pp}$.

MitcheLl, W. I. (ed.). 2004. The Geology of Northern Ireland-Our Natural Foundation. Geological Survey of Northern Ireland, Belfast.

Monaghan, A. A. \& Pringle, M. S. 2014. ${ }^{40} \mathrm{Ar} /{ }^{39} \mathrm{Ar}$ geochronology of Carboniferous-Permian volcanism in the Midland Valley, Scotland. In: Wilson, M., NEumann, E.-R., DavieS, G.R., Timmermann, M.J., Heeremans, M. \& Larsen, B.T. (eds.). Permo-Carboniferous Magmatism and Rifting in Europe. Geological Society, London, Special Publications, 223, 219-241.

Monaghan, A. A. 2014. The Carboniferous shales of the Midland Valley of Scotland: geology and resource estimation. British Geological Survey for Department of Energy and Climate Change, London, UK.

NADIN, P A, \& KUZNIR, N J. 1995. Palaeocene uplift and Eocene subsidence in the northern North Sea Basin from 2D forward and reverse stratigraphic modelling. Journal of the Geological Society of London, 152, 833-848.

Newman, P. J. 1999. The geology and hydrocarbon potential of the Peel and Solway Basins, East Irish Sea. Journal of Petroleum Geology, 22, 305-324.

Oliver, G.J.H., Stone, P. \& Bluck, B.J. 2002. The Ballantrae Complex and the Southern Uplands Terrane. In: TREWIN, N.H. (ed). Geology of Scotland. Fourth Edition. Geological Society, London, 149-166.

PARNELL, 1997. Fluid migration history in the North Irish Sea-North Channel region. In: MEADOwS, N.S., Trueblood, S.P., Hardman, M. \& Cowan, G. (eds.), Petroleum Geology of the Irish Sea and Adjacent Areas. Geological Society, London, Special Publications, 124, 213-228.

PEACE, G.R. \& BESLY, B.M. 1997. End-Carboniferous fold-thrust structures, Oxfordshire, UK: implications for the structural evolution of the late Variscan foreland of south-central England. Journal of the Geological Society of London, 154, 225-237.

Penn, I., Holliday, D. W., Kirby, G. A., Kubala, M., Sobey, R. A., Mitchell, W. I., Harrison, R. K. \& BeCKINSALE, R. D. 1983. The Larne No. 2 Borehole: discovery of a new Permian volcanic centre. Scottish Journal of Geology, 19, 333-34

PharaOH, T.C., KirK, K., QuinN, M., SANKey, M. \& Monaghan, A.A. 2016a. Seismic Interpretation and generation of depth surfaces for late Palaeozoic strata in the Irish Sea Region. British Geological Survey Commissioned Report, CR/16/041. 65pp. $\mathrm{http} / / /$ nora.nerc.ac.uk/cgi/search/archive/simple?screen=Search\&dataset=archive\&order=\&q= 21CXRM\&_action_search=Search 
Pharaoh, T. C., Winchester, J. A., Verniers, J., Lassen, A., \& SEghedi, A. 2006. The western accretionary margin of the east European craton: an overview. In: GEE, D.G.and STEPHENSON, R.A. (Eds). European Lithosphere Dynamics. Geological Society, London, Memoir 32, 291-311.

Pharaoh, T. C., Vincent, C. J., Bentham, M. S., Hulbert, A. G., Waters, C. N., \& Smith, N. J. 2011. Structure and evolution of the East Midlands region of the Pennine Basin. Subsurface memoir of the British Geological Survey. 144pp.

Pharaoh, T.C., Smith, N.J.P., KirK, K., Kimbell, G.S., Gent, C., Quinn, M., \& Monaghan, A.A. 2016b. Palaeozoic Petroleum Systems of the Irish Sea. British Geological Survey Commissioned Report, CR/16/045. 135pp.

Pharaoh, T.C., Dusar, M., Geluk, M., Kockel, F., Krawczyk, C., Krzywiec, P., ScheckWenderoth, M., Thybo, H., VejBaeK, O. \&VAn Wees, J-D.. 2010. In: Doornenbal, J. H.\& Stevenson, A. G.(eds.). Chapter 3 Tectonic Evolution Petroleum Geological Atlas of the Southern Permian Basin Area. EAGE Publications b.v., Houten, 25-58.

Pletsch, T., ApPel, J., Botor, D., Clayton, C.J., Duin, E J T., Faber, E., Gorecki, W., Kombrink, H., Kosakowski, P., Kuper, G.,Kus, J., Lutz, R., Mathiesen, A., Ostertag-Henning, C., PAPIERNEK, B. \& VAN Bergen, F. 2010. Chapter 12 Petroleum generation and migration. In: Doornenbal, J. C. \& Stevenson, A. G. (eds.). Petroleum Geological Atlas of the Southern Permian Basin Area. EAGE Publications b.v., Houten, 225-253.

PROVIDENCE, 2013. Frontier exploration opportunities Rathlin Trough, offshore Northern Ireland. PROSPEX, Dec 2013.

Puchkov, V. N. 1997. Structure and geodynamics of the Uralian orogeny. In: BurG, J. -P., \& ForD, M. (eds.). Orogeny Through Time. Geological Society, London, Special Publications, 121, 201-236.

QUINN, M. F. 2008. A geological interpretation of the Larne and Portpatrick sub-basins, offshore Northern Ireland, with an evaluation of an area proposed for gas storage in salt caverns. British Geological Survey Commissioned Report, CR/08/064. 77pp. Commercial-inConfidence.

QUiRK, D. G., \& KimBELL, G. S. 1997. Structural evolution of the Isle of Man and central part of the Irish Sea. In: Meadows, N. S., Trueblood, S., Hardman, M., \& Cowan, G. (eds.). Petroleum Geology of the Irish Sea and adjacent areas. Geological Society, London, Special Publications, 124. 135-159.

QuiRK, D. G., RoY, S., KNOTT, I., RedFern, J. \& HiLl, L., 1999. Petroleum geology and future hydrocarbon potential of the Irish Sea. Journal of Petroleum Geology, 22, 243-260.

RACEY, A. 1999. Palynolgical and geochemical analysis of Carboniferous borehole and outcrop samples from the Isle of Man. Journal of Petroleum Geology, 22, 349-362.

RAmsBotToM, W. H. C. 1969. Reef distribution in the British Lower Carboniferous. Nature, 222, 765-766.

Ramsbottom, W. H. C., CAlVER, M.A., EAGAR, R.M.C., HOdSON, F., HOllidAY, D.W., STUBBLEFIELD, C.J., \& WILSON, R.B. 1978. A Correlation of Silesian Rocks in the British Isles. Geological Society, London, Special Reports 10. 
Read, W.A., Browne, M.A., StePhEnson, D. \& Upton, B.G.J. Carboniferous. Chapter 9 In: TREwIN, N.H. (ed). Geology of Scotland. Fourth Edition. Geological Society, London, 149166.

REAY, D.M. 2004. Oil and Gas. In: Mitchell, W.I. (ED.). The Geology of Northern IrelandOur Natural Foundation. Geological Survey of Northern Ireland, Belfast. ISBN 085272-454-3. 273-290

REAY, D.M. 2012. Geology and Gas in Northern Ireland. Future of natural gas seminar. Dundalk, Ireland. March 2012.

Scheck-Wenderoth, M., Krzywiec, P., ZÜhlke, R., Maystrenko, Y. \& Froitzheim. 2008. Permian to Cretaceous tectonics. In: McCann, T. (ed.). The Geology of Central Europe. Volume 2: Mesozoic and Cenozoic. Geological Society, London, 999-1030.

SHELton, R. 1997. Tectonic evolution of the Larne Basin. In: MEadows, N.S., TRUeBlood, S.P., Hardman, M. \& Cowan, G. (eds.), Petroleum Geology of the Irish Sea and Adjacent Areas. Geological Society, London, Special Publications, 124, 113-134.

SMith, M., RoberTson, S. \& Rollin, K.E. 1999. Rift basin architecture and stratigraphical implications for basement-cover relationships in the Neoproterozoic Grampian Group of the Scottish Caledonides. Journal of the Geological Society, London, 156, 1163-1173.

Smith, N. J. P. (Compiler) 1985. Map 1: Pre-Permian Geology of the United Kingdom (South). 1:1,000,000 scale. British Geological Survey, Nottingham.

SMITH, N. J. P. 1999. Gas seepage: shrines, curiosities and hazards. Earthwise, 14, 9. British Geological Survey, Nottingham.

SMith, N. J. P. (in prep.). The UK's unconformity maps used for assessing basin configuration and in support of hydrocarbon prospectivity. Conference at Geological Society, May 26-27, 2016.

Smith, N. J. P., Chadwick, R. A., Warrington, G., Kirby, G. A. \& Jones, D. 1995. The hydrocarbon prospectivity of the Cheshire Basin and surrounding areas. BGS Technical Report WA/94/95C. $37 \mathrm{pp}$.

SMith, N. J. P., Kirby, G. A. \& PHARAOH, T. C. 2005. Structure and evolution of the south-west Pennine Basin and adjacent area. Subsurface Memoir of the British Geological Survey. (Keyworth, Nottingham: British Geological Survey.)

StUART, I.A. 1993. The geology of the North Morecambe Gas Field, East Irish Sea Basin. Jn: PARKer, J. R. (ed.). Petroleum Geology of Northwest Europe: Proceedings of the 4th Conference. Geological Society, London, 883-895.

StUART, I. A. \& CowAn, G. 1991. The south Morecambe Field, blocks 110/2a, 110/3a, 110/8a, UK East Irish Sea. In: AвBотTS, I. L. (ed.). United Kingdom Oil and Gas Fields, 25 Years Commemorative Volume. Geological Society, London, Memoir 14, 527-541.

SUESS, E. 1904. The Face of the Earth. Clrendon Press, Oxford.

Thompson, J. \& Meadows, N.S. 1997. In: Meadows, N.S., Trueblood, S.P., Hardman, M. \& CowAN, G. (eds.), Petroleum Geology of the Irish Sea and Adjacent Areas. Geological Society, London, Special Publications, 124, 237-252. 
Timmerman, M.J. 2004. Timing, geodynamic setting and character of Permo-Carboniferous magmatism in the foreland of the Variscan Orogen, NW Europe. In: WILSON, M., NEUMANN, E.-R., Davies, G.R., Timmermann, M.J., HeEremans, M. \& Larsen, B.T. (eds.). PermoCarboniferous Magmatism and Rifting in Europe. Geological Society, London, Special Publications, 223, 219-241.

Trewin, N.H. \& ThIRLwall, M.F. 2002. Old Red Sandstone. Chapter 8. In: Trewin, N.H. (ed). Geology of Scotland. Fourth Edition. Geological Society, London, 149-166.

Trotter, F. M. 1954. Reddened beds in the Coal Measures of Lancashire. Bulletin of the Geological Survey, 5, 61-80.

UNDERHILL, J. R. 2003. The tectonic and stratigraphic framework of the United Kingdom's oil and gas fields. In GluYAS, J. G. \& HiChENS, H. M. (eds.). United Kingdom Oil and Gas Fields, Commemorative Millennium Volume. Geological Society, London, Memoir 20, 17-59.

Underhill, J. R., Monaghan, A. A. \& Browne, M. A. E. 2008. Controls on structural styles, basin development and petroleum prospectivity in the Midland Valley of Scotland. Journal of Marine and Petroleum Geology, 25, 1000-1022

VAN Hoorn, B. 1987. Structural evolution, timing and tectonic style of the Sole Pit inversion. Tectonophysics, 137, 239-284.

Vane, C. H., Uguna, C., KiM, A. W. \& Monaghan, A. A., 2016. Organic Geochemistry of Palaeozoic Source Rocks of the Irish Sea, UK. British Geological Survey. Commissioned Report.

CR/16/044. http://nora.nerc.ac.uk/516753/

WAKEFIELD, O., WATERS, C.N., \& SMITH, N.J.P. 2016. Carboniferous stratigraphical correlation and interpretation in the Irish Sea. British Geological Survey Commissioned Report, CR/16/040. $81 \mathrm{pp}$.

WALKDEN, G. M. \& DAVIES, J. R. 1983. Polyphase erosion of subaerial omission surfaces in the late Dinantian of Anglesey. Sedimentology, 30, 861-878.

WARD, J. 1997. Early Dinantian evaporites of the Easton-1 well, Solway basin, onshore, Cumbria, England. In: Meadows, N.S., Trueblood, S.P., Hardman, M. \& Cowan, G. (eds.), Petroleum Geology of the Irish Sea and adjacent areas. Geological Society, London, Special Publications, 124, 277-296.

WarRington, G. 1997. The Penarth Group-Lias Group succession (Late Triassic-Early Jurassic) in the East Irish Sea Basin and neighbouring areas: a stratigraphical review. In: MEADOwS, N.S., Trueblood, S.P., Hardman, M. \& Cowan, G. (eds.), Petroleum Geology of the Irish Sea and Adjacent Areas. Geological Society, London, Special Publications, 124, 33-46.

WATERS, C. N. \& CONDON, D. J. 2012. Nature and timing of Late Mississippian to MidPennsylvanian glacio-eustatic sea-level changes of the Pennine Basin, UK. Journal of the Geological Society, 169, 37-51.

WAters, C. N., Somerville, I. D., Jones, N. S., Cleal, C. J., Collinson, J. D., WATERS, R. A., Besly, B. M., DeAn, M. T., StePhenson, M. H., DAVIES, J. R., Freshney, E. C., JaCKSON, D. I., Mitchell, W. I., POWEll, J. H., BARClay, W. J., BRowne, M. A. E., LeVERIDGe, B. 
E., LONG, S. L. \& MCCLEAN, D. (EDS.). 2011. A revised correlation of Carboniferous rocks in the British Isles. Geological Society, London, Special Reports, 26.

WHITE, R. S. 1988. A hot-spot model for early Cenozoic volcanism in the North Atlantic. In: PARSON, L. M., \& MORTON, A. C. (eds.). Early Cenozoic volcanism and the opening of the North Atlantic. Geological Society, London, Special Publications, 39. 3-13.

WhitTAKER, A., 1985 Atlas of Onshore Sedimentary basins. Blackie/British Geological Survey

WOOD, I. 2014. UKCS Maximising Recovery Review: Final Report. HMSO; London.

WoOdCOCK, N.H. \& SOPER, N.J. 2006. The Acadian Orogeny: The mid-Devonian phase of deformation that formed slate belts in England and Wales. .In: BRENCHLEY, P.J. \& Rawson, P.F. (eds) 2006. The Geology of England and Wales. Second Edition. Geological Society, London, 103-129.

WOODWARD, K. \& CURTIS, C. D. 1987. Predictive modelling of the distribution of production constraining illites - Morecambe Gas Field, Irish Sea, Offshore UK. In: BROOKS, J. \& GLENNIE, K. (eds.). Petroleum Geology of North West Europe. Graham \& Trotman, London, 205-215.

Yaliz, A. M. 1997. The Douglas Oil Field. In: Meadows, N. S., Trueblood, S. P., Hardman, M. \& CowAn, G. (eds.), Petroleum Geology of the Irish Sea and Adjacent Areas. Geological Society, London, Special Publications, 124, 399-416.

YALIZ, A. \& TAYLOR, P. 2003. The Hamilton and Hamilton North Gas Fields, Block 110/13a, East Irish Sea. In: GluYAS, J. G. \& Hitchens, H. M. (eds.) United Kingdom Oil and Gas Fields, Commemorative Millennium Volume. Geological Society, London, Memoir 20, 77-86.

ZIEGLER, P. A. 1990. Geological Atlas of Western and Central Europe. Second Edition. Elsevier for Shell Internationale Petroleum Maatschappij B. V., Amsterdam.

Zonenshain, L.P., Korinevsky, V. G., KaZmin, V. G. , PeChersky, D.M., Khain, V. V.,\& MATEVEENKOV, V. V. 1984. Plate tectonic model of the south Urals development. Tectonophysics, 109, 95-135.

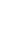

(1)


Fig. 1. Key data evaluated during the study (2D seismic, black; 3D seismic outline, orange; wells proving Carboniferous strata, black dot; wells used in the petrophysical study, black square).

Fig. 2. Key Mississippian structural elements of the greater Irish Sea province. Incorporates information from Maddox et al. (1997), Parnell (1997) and Shelton (1997). Location of Permo-Triassic basinal features, following Jackson \& Mulholland (1993) and BGS (1994), for reference purposes, in red: BB, Berw Basin; CP, Conwy Platform; DP, Deemster Platform; EB, Eubonia Basin; ED, East Deemster Basin; GB, Gogarth Basin; GC, Godred Croven Basin; KB, Keys Basin; LB, Lagman Basin; MF, Manx-Furness Ridge; NC, North Channel Basin; OP, Ogham Platform; PB, Peel Basin; Q109S, Quadrant 109 Syncline; SB, Solway Basin; TB, Tynwald Basin; WD, West Deemster Basin. Location of sections depicted in later figures: red line, seismic profiles (Fig. 3); green line, synoptic diagrams (Figs. 4, 5); black line, well transects (Fig. 9).

Fig. 3. Seismic reflection data. Locations are shown in Figs. 2 and 6. N.B. vertical scales in s TWTT.

a. Migrated seismic reflection line NW-SE across Quadrant 109: JEBCO JS-MANX-138. Includes content supplied by IHS Global Limited. Copyright $\odot$ IHS Global Limited (2016). All rights reserved. Note the considerable thickness of Carboniferous strata in the Eubonia Tilt-block, here exceeding $2.5 \mathrm{~s}$ TWTT; brighter reflectivity towards top of tilt-block below Intra-Visean unconformity, possibly reflecting reefal development; and in the south, a northward-vergent anticline-thrust inversion couple, defining the northern edge of the Môn-Deemster Basin. The presence of Warwickshire Group strata is inferred from seismostratigraphic principles and has not yet been confirmed by drilling.

b. Arbitrary NNW-SSE line through the migrated 3D TerraCube ${ }^{\circledR}$ dataset, supplied courtesy of CGG GeoSpec. Note the presence of a series of inversion anticlines (Môn-Deemster Foldbelt) in the Carboniferous sequence, associated with thrusts (fault-plane reflections) which penetrate into the Caledonian basement. A less steeply dipping detachment is present at depth. The Bowland Shale Formation is inferred to occupy a rather transparent zone, sandwiched between more reflective Carboniferous Limestone Group (below) and Millstone Grit Group (above). The mildly deviated well 110/07b-6 proved $450 \mathrm{~m}$ of Bowland Shale Formation before terminating in strata of Pendleian age (unbottomed). Westphalian strata have been almost completely eroded following strong inversion during the earliest Variscan phase. Inversion anticlines of this generation were reactivated 'posthumously' by further compression during the Alpine Orogeny in Miocene time, producing more gentle anticlines in the Permo-Triassic cover, including the traps in the Ormskirk Sandstone Formation (Top SSG pick) hosting the Conwy, Douglas and other fields.

Fig. 4. Synoptic diagrams ('cartoons') to illustrate principal elements of the hydrocarbon system of the greater Irish Sea province. Locations are shown in Figs. 2 and 6. N.B. vertical scales in s TWTT. The basin names used are principally those of the Permo-Triassic EISB and contemporary basins (Jackson \& Mulholland, 1993; BGS, 1994), rather than those of the Carboniferous elements newly named here:

a. Principal elements of the hydrocarbon system in the Eubonia Basin and Q109 Arch. Transect is parallel to Fig. 3a and father east, into the Eubonia Basin.

b. Principal elements of the EISB from the Lagman Fault (north) to the Welsh margin (south). The northern part crosses from the Ogham Platform, to the Lagman and Keys basins, where Westphalian strata are almost completely removed, the West Deemster Basin and Deemster Platform. Note thickening of the Bowland Shale Formation beneath Deemster Platform, associated with the offshore 
extension of the Bowland Basin. The southern part crosses the Môn-Deemster Foldbelt and is virtually colinear with Fig. $3 b$.

c. Principal elements of the hydrocarbon system in the Peel Basin. Note that fault displacements appear to be largely of post-Permian age, indicating little if any syn-depositional thickening across the Visean carbonate platform. Post-Visean strata were only preserved on the Manx margin.

Fig. 5. Synoptic diagrams ('cartoons') to illustrate principal elements of the hydrocarbon system of the greater Irish Sea province. Locations are shown in Figs. 2 and 6. N.B. vertical scales in s TWTT. The basin names used are principally those of the Permo-Triassic EISB and contemporary basins (Jackson \& Mulholland, 1993; BGS, 1994), rather than those of the Carboniferous elements newly named here:

a. Principal elements of the hydrocarbon system in the eastern part of the Solway Firth Basin. Note the preservation of late Westphalian Warwickshire Group (Whitehaven Sandstone Formation) in the Cumbrian Coalfield adjacent to the Maryport Fault, and the axis of Alpine inversion significantly offset from the Variscan one. The Visean strata here are Border Group and Yoredale facies, with uncertain source potential.

b. Principal elements of the hydrocarbon system in the northern part of the EISB. The WSW-ENE transect crosses Variscan second phase inversion structures obliquely in the Ogham Inlier, western Keys Basin and the Cumbrian margin.

c. Principal elements of the hydrocarbon system in the southern part of the EISB. The W-E transect is located parallel to the southern edge of the Môn-Deemster Foldbelt, crossing some of the Variscan first inversion phase structures obliquely. N-S trending inversion structures of the second Variscan phase at the margins of the East Deemster Basin and on the Formby Platform are crossed obliquely. Note the excision of Westphalian strata on these inversion systems. Modified from Yaliz (1997; Figure 4).

Fig.6. Pre-Permian subcrop map showing key Variscan inversion structures (after Pharaoh et al. 2016b). Variscan inversion structures in Ogham Platform after Quirk \& Kimbell (1997). Abbreviated structure names: DP, Deemster Platform; EDB, East Deemster Western Boundary Fault; FPF, Formby Point Fault; OP, Ogham Platform; RE, Ribble Estuary Inlier. Location of sections depicted in other figures: red line, seismic profiles (Fig. 3); green line, synoptic diagrams (Figs. 4, 5); black line, well transects (Fig. 9). Hydrocarbon fields from OGA website:

http://data.ogauthority.opendata.arcgis.com/datasets/

Fig.7. Petroleum system elements in a north-south transect across the central part of the region

Fig.8. Pendleian palaeogeography showing the Bowland Shale source rock distribution and lateral variation with Millstone Grit facies (from Wakefield et al. 2016).

Fig. 9. Well transects (from Wakefield et al. 2016). Locations are shown in Figs. 2 and 6. a. N-S transect across the EISB from the Lagman Basin to Rhuddlan, onshore North Wales. Note the truncation of the Warwickshire Group north of Point of Ayr and condensation of the underlying Westphalian strata, southward onto the Cambrian margin. Also note the variation in the thickness of the Appleby Group. b. W-E transect across the centre of the EISB from 109/5-1 in the Eubonia Basin to Roosecote, onshore north Cumbria.

Fig.10. Seismic structure map in depth (metres sub-sea level) for the Intra-Namurian pick, equated with the base of the Millstone Grit Group. For location of abbreviated Permo-Triassic basinal features (for reference purposes), refer to key to Figure 2. 
1420 Fig.11. A summary of the available geochemical data for Bowland Shale Formation lithologies in well 1421 110/07b-6 and 110/02b-10. Data sourced from released legacy reports. Note that no Oxygen Index data are available for well 110/07b-6, so the data in the Pseudo-Van Krevelen Plot (Figure 11b) is from well

Fig.12. Modelled burial history for 110/07b- 6 showing that the Bowland Shale source rock entered the main gas generation window in the late Cretaceous-early Cenozoic. The well terminates within the Bowland Shale Formation.

Fig.13. Cross plot of core porosity and permeability for East Irish Sea Basin samples. For key to abbreviations see Table 1, except for: PLC, Pennine Lower Coal Measures; PMCM, Pennine Middle Coal Measures; WAWK, Warwickshire Group.

Table 1. Synthesis of petrophysical results by formation (from Hannis, 2016). NTG = Net reservoir thickness to gross formation thickness. Porosity and net-to-gross are expressed as a fraction. Minimum porosity in the log-derived porosity range is 0.05 , the net reservoir porosity cut-off value. Permeability figures are in $\mathrm{mD}$. Core porosity and permeability data are synthesised from legacy reports. 
From: EIS_Summary_Petrophysics_final.xlsx in 21CXRM_IrishSea_PoropermPetrop]

\begin{tabular}{|c|c|c|c|c|c|}
\hline & & & & & $\overline{L o g}$ der \\
\hline $\begin{array}{l}\text { Stratigraphic } \\
\text { unit name }\end{array}$ & Code & $\begin{array}{c}\text { Net } \\
\text { thickness } \\
(\mathrm{m}) \\
\end{array}$ & NTG & $\begin{array}{l}\text { Highest } \\
\text { Average } \\
\text { Porosity }\end{array}$ & $\begin{array}{l}\text { Porosity } \\
\text { range }\end{array}$ \\
\hline $\begin{array}{l}\text { Cumbrian Coast } \\
\text { Group }\end{array}$ & $\mathrm{CCO}$ & 81 & 0.07 & 0.14 & $0.05-0.43$ \\
\hline Appleby Group & APY & 936 & 0.79 & 0.19 & $0.05-0.40$ \\
\hline $\begin{array}{l}\text { Pennine Coal } \\
\text { Measures } \\
\text { Group }\end{array}$ & PCM & 62 & 0.09 & 0.11 & $0.05-0.26$ \\
\hline $\begin{array}{l}\text { Millstone Grit } \\
\text { Group }\end{array}$ & MG & 293 & 0.10 & 0.11 & $0.05-0.31$ \\
\hline Yoredale Group & YORE & 16 & 0.02 & 0.07 & $0.05-0.30$ \\
\hline $\begin{array}{l}\text { Bowland Shale } \\
\text { Formation }\end{array}$ & BSG & 16 & 0.03 & 0.07 & $0.05-0.23$ \\
\hline $\begin{array}{l}\text { Carboniferous } \\
\text { Limestone } \\
\text { Supergroup }\end{array}$ & $\mathrm{CL}$ & 0 & 0.00 & 0.05 & $0.05-0.05$ \\
\hline
\end{tabular}





\begin{tabular}{|c|c|c|c|c|c|c|}
\hline \multicolumn{3}{|l|}{ ived } & \multicolumn{4}{|c|}{ Core measured } \\
\hline \multirow{2}{*}{$\begin{array}{c}\text { Highest } \\
\text { Average } \\
\text { Permeability } \\
\text { estimate }\end{array}$} & \multirow[b]{2}{*}{$\begin{array}{l}\text { Permeability } \\
\text { estimate range }\end{array}$} & \multirow[b]{2}{*}{ 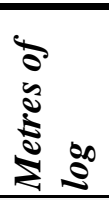 } & \multirow{2}{*}{$\begin{array}{l}\text { Highest } \\
\text { Average } \\
\text { Porosity }\end{array}$} & \multirow[b]{2}{*}{$\begin{array}{c}\text { Porosity } \\
\text { range }\end{array}$} & \multicolumn{2}{|c|}{ Highest Average } \\
\hline & & & & & $\begin{array}{c}\text { horizontal } \\
\quad(\mathbf{k h})\end{array}$ & $\begin{array}{c}\text { vertical } \\
(\mathbf{k v})\end{array}$ \\
\hline 0.17 & $0.02-1.39$ & 1197 & 0.04 & $0.02-0.07$ & 3.06 & \\
\hline 6.89 & $0.17-82.27$ & 1191 & 0.13 & $0.05-0.21$ & 0.80 & 7.90 \\
\hline 0.79 & $0.02-61.45$ & 795 & 0.06 & $0.01-0.10$ & 1.07 & 0.01 \\
\hline 367.74 & $0.17-10000$ & 2971 & 0.06 & $0-0.10$ & 0.04 & 0.05 \\
\hline & & 783 & 0.01 & 0.00 & 0.00 & 0.00 \\
\hline 0.75 & $0.15-16.19$ & 551 & & & & \\
\hline & & 246 & & & & \\
\hline
\end{tabular}





\begin{tabular}{|c|c|c|c|}
\hline \multicolumn{2}{|c|}{ Permeability estimate } & \multirow[b]{2}{*}{$\frac{\tilde{u}^{2}}{5}$} & \multirow[b]{2}{*}{ Comments } \\
\hline $\begin{array}{c}\text { horizontal } \\
(\mathbf{k h})\end{array}$ & $\begin{array}{c}\text { vertical } \\
(\mathbf{k v})\end{array}$ & & \\
\hline $0.01-15.20$ & & 6 & \\
\hline $0.00-1.72$ & $0.17-71.5$ & 154 & $\begin{array}{l}\text { Highest net to gross, highest porosity. } \\
\text { Highest permeabilities values in the } \\
100 \mathrm{mD} \text { - }\end{array}$ \\
\hline $0.00-9.43$ & $0.01-0.13$ & 55 & $\begin{array}{l}\text { Low NTG (although third highest of the } \\
\text { units examined). Reasonable average } \\
\text { porosity. Permeabilities appear low. } \\
\text { (Highest values of } 61.4 \mathrm{mD} \text { in } 1 \text { well, but } \\
\text { with no core data over that interval). }\end{array}$ \\
\hline $0.00-0.37$ & $0.00-0.13$ & 49 & $\begin{array}{l}\text { Highest permeability (although estimated } \\
\text { with low confidence: seen in only } 1 \text { of } 3 \\
\text { wells (113/27-2), with a relatively poor core- } \\
\text { log data fit). Low NTG (although second } \\
\text { highest of the units examined). }\end{array}$ \\
\hline \multirow[t]{3}{*}{0.00} & 0.00 & 9 & \\
\hline & & 0 & \\
\hline & & 0 & $\begin{array}{l}\text { Matrix porosities are less than } 5 \% \text { therefore } \\
\text { the unit is not considered to have any 'net' } \\
\text { using the cut offs applied. }\end{array}$ \\
\hline
\end{tabular}
























































































































































































































































































































































































































































































































































































































































































































































































































































































































































































































































































































































































































































































































































































































































































































































































































































































































































































































































































































































































































































































































































































































































































































































































































































































































































































































































































































































































































































































































































































































































































































































































































































































































































































































































































































































































































































































































































































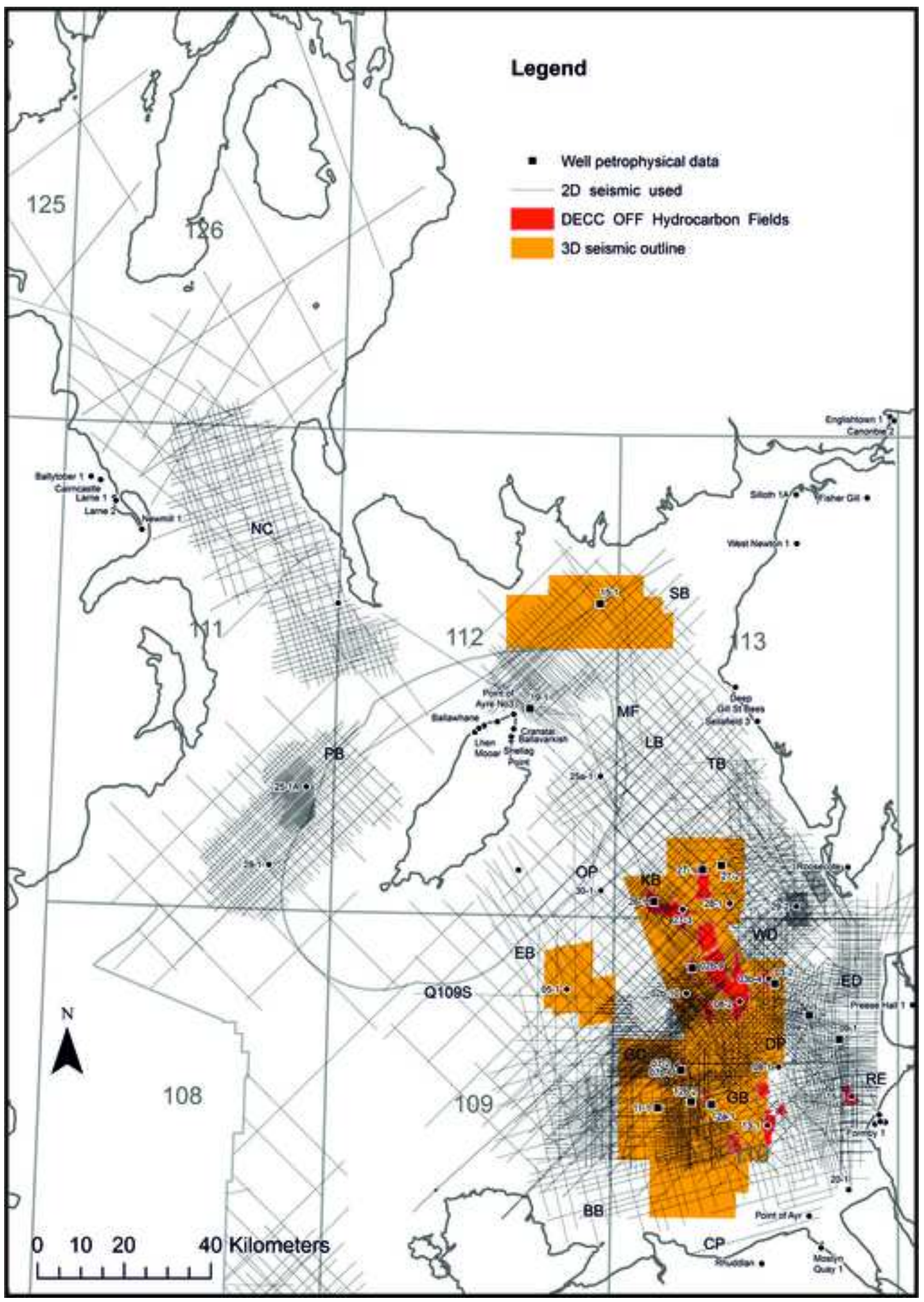




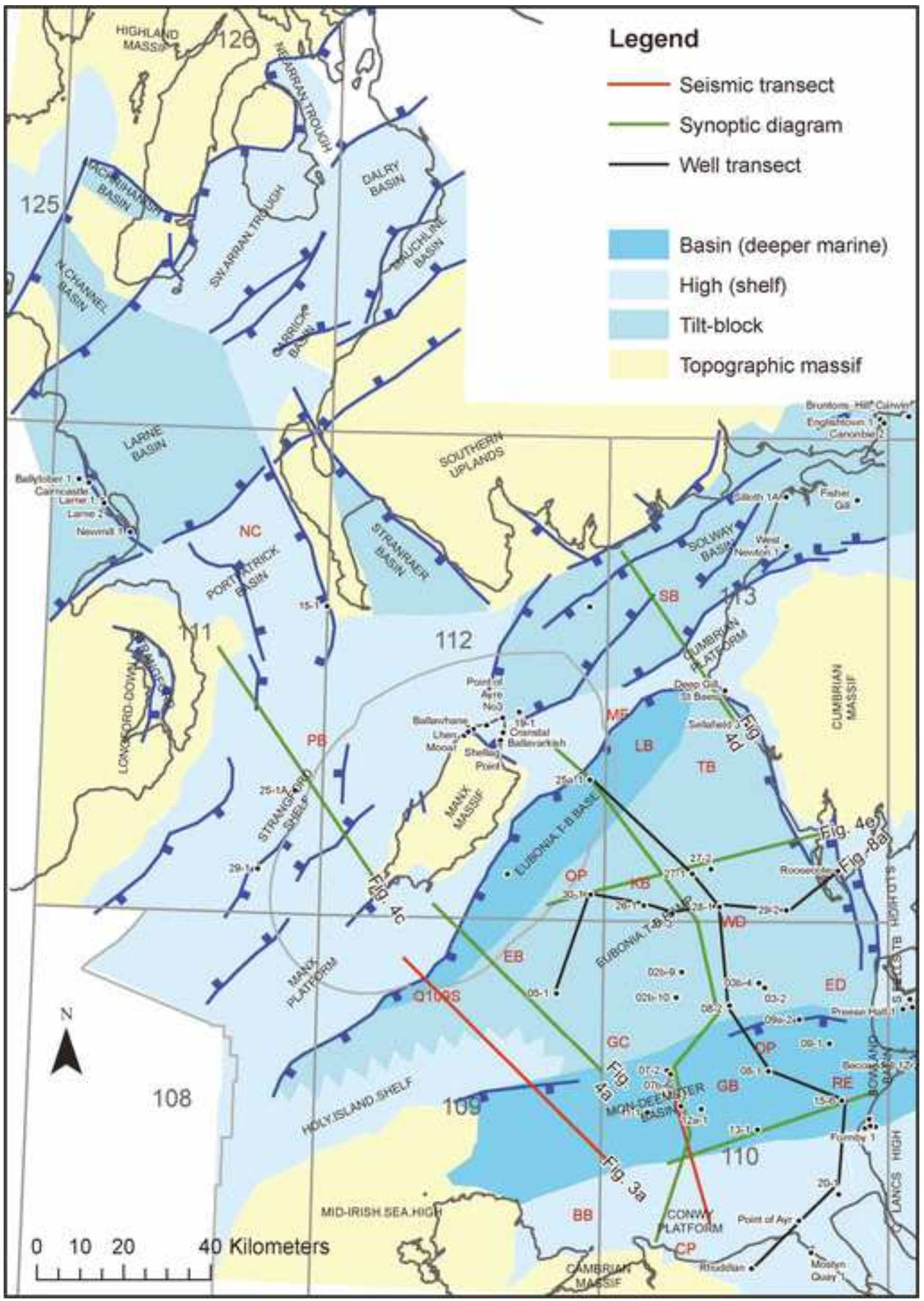




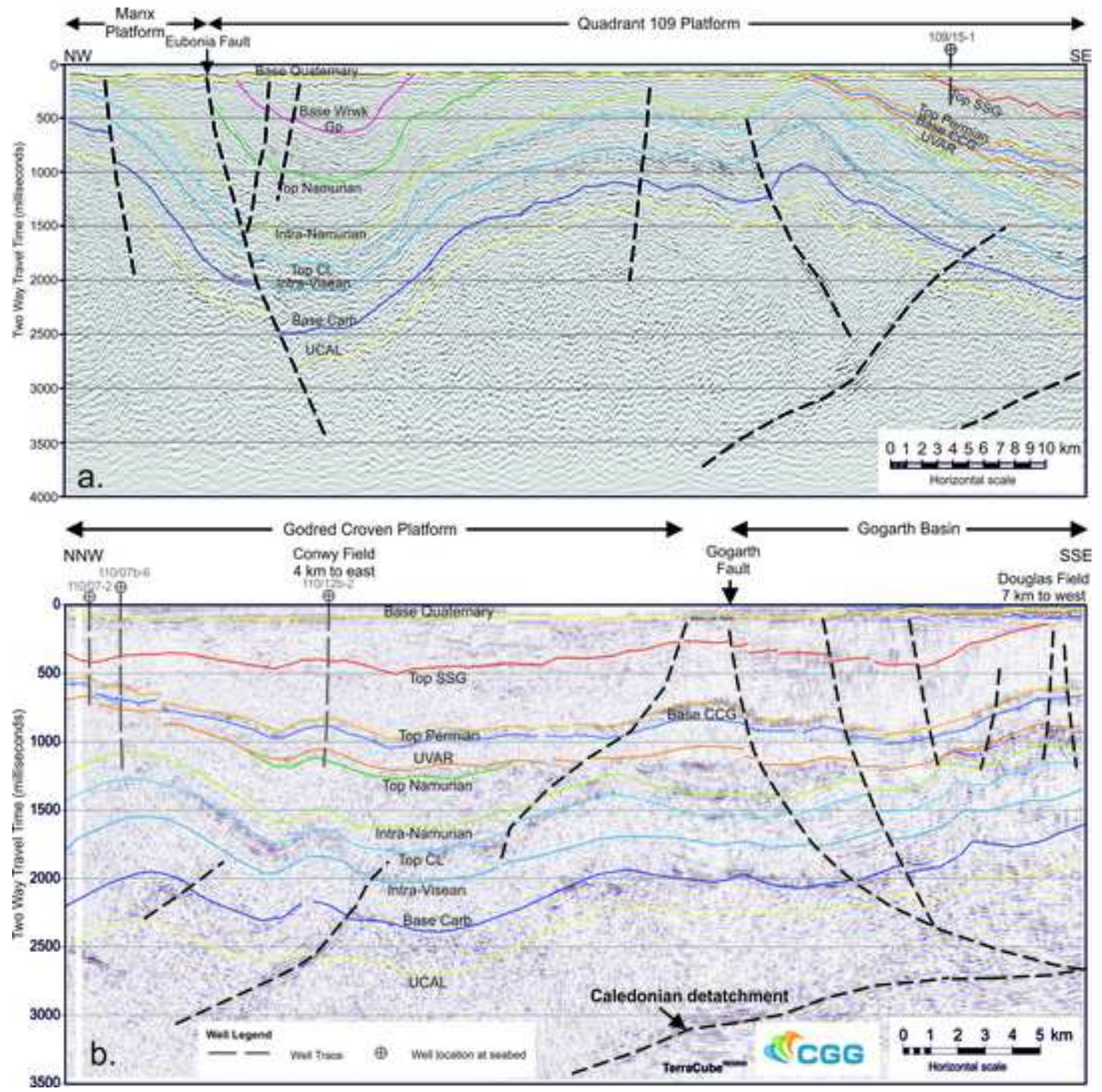




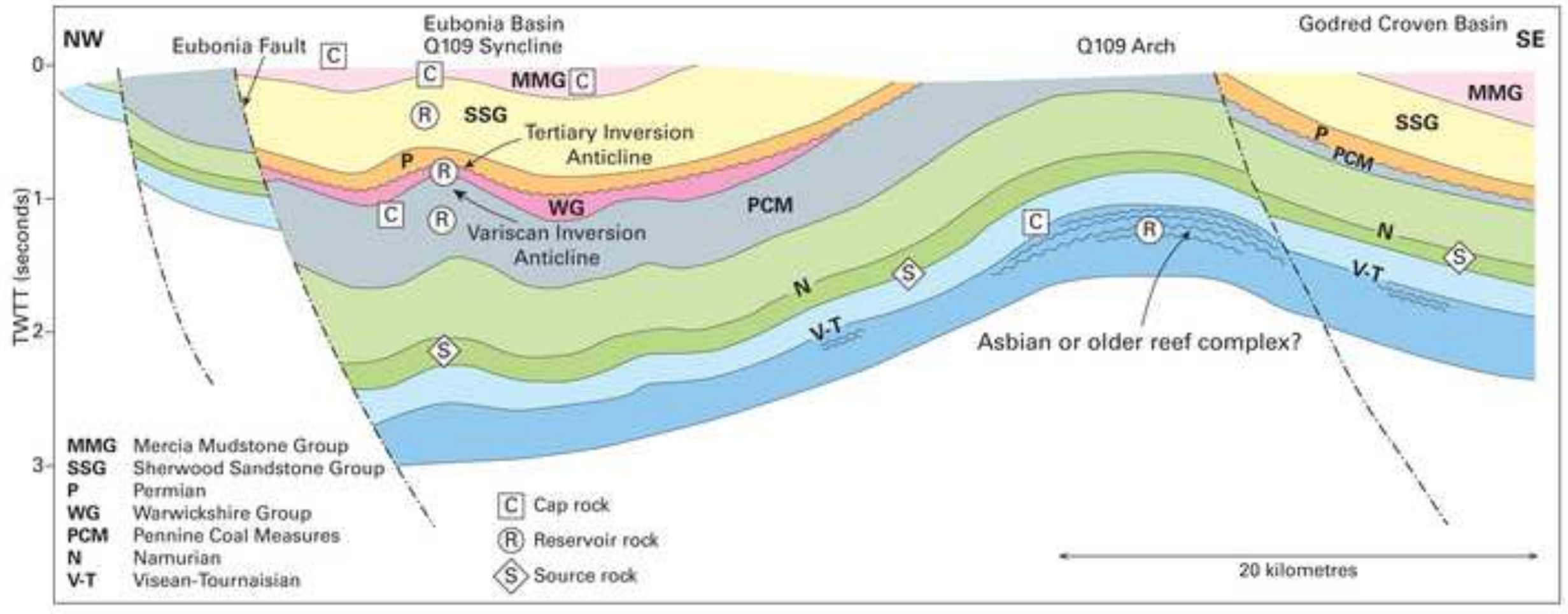

$0-$

NW Eubonia Fault Eubonia Basin

C) MMG C

(B) SSG

WG PCM

MMG Mercia Mudstone Group

SSG Sherwood Sandstone Group

WG Warwickshire Group

$\mathrm{PCM}$ Pennine Coal Measures:- (B) Reservoir rock
$\mathrm{N}$

V-T Visean-Tournaisian

(S) Source rock 


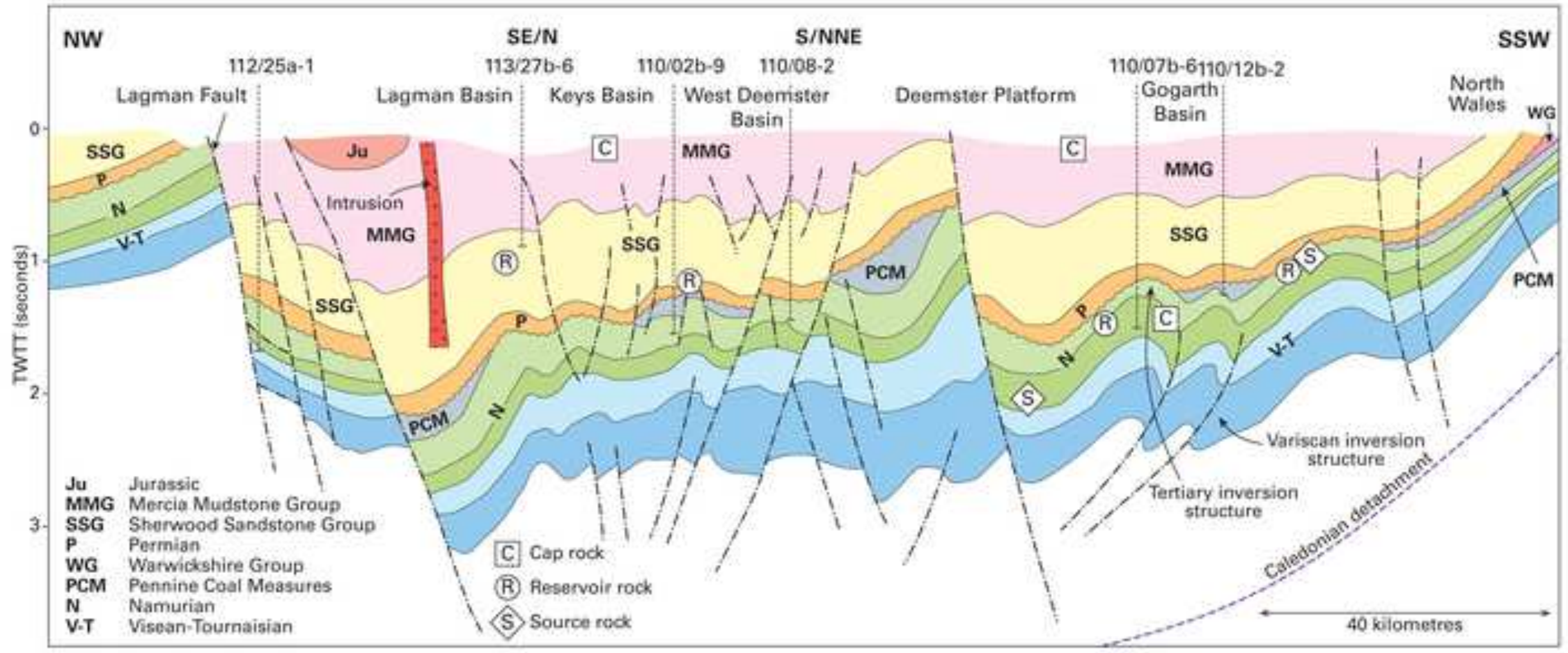




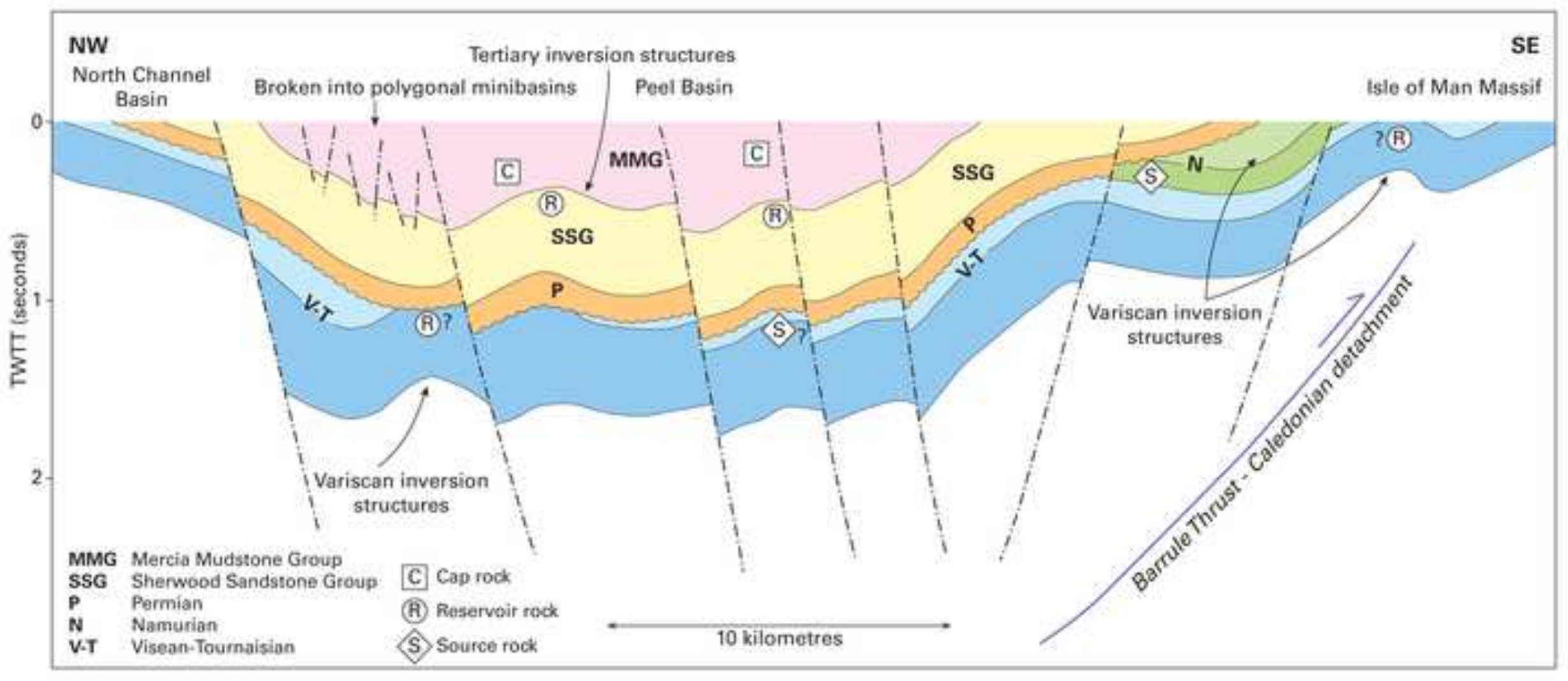




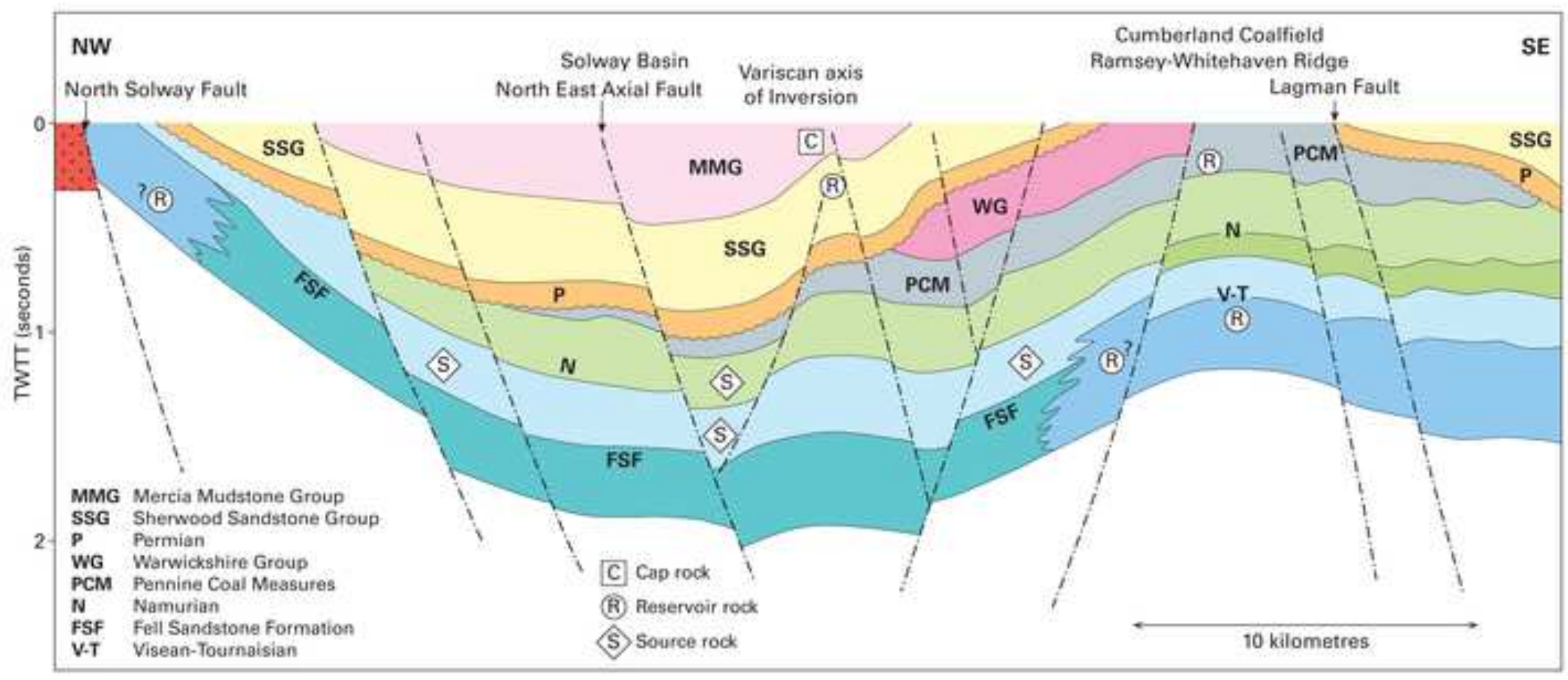




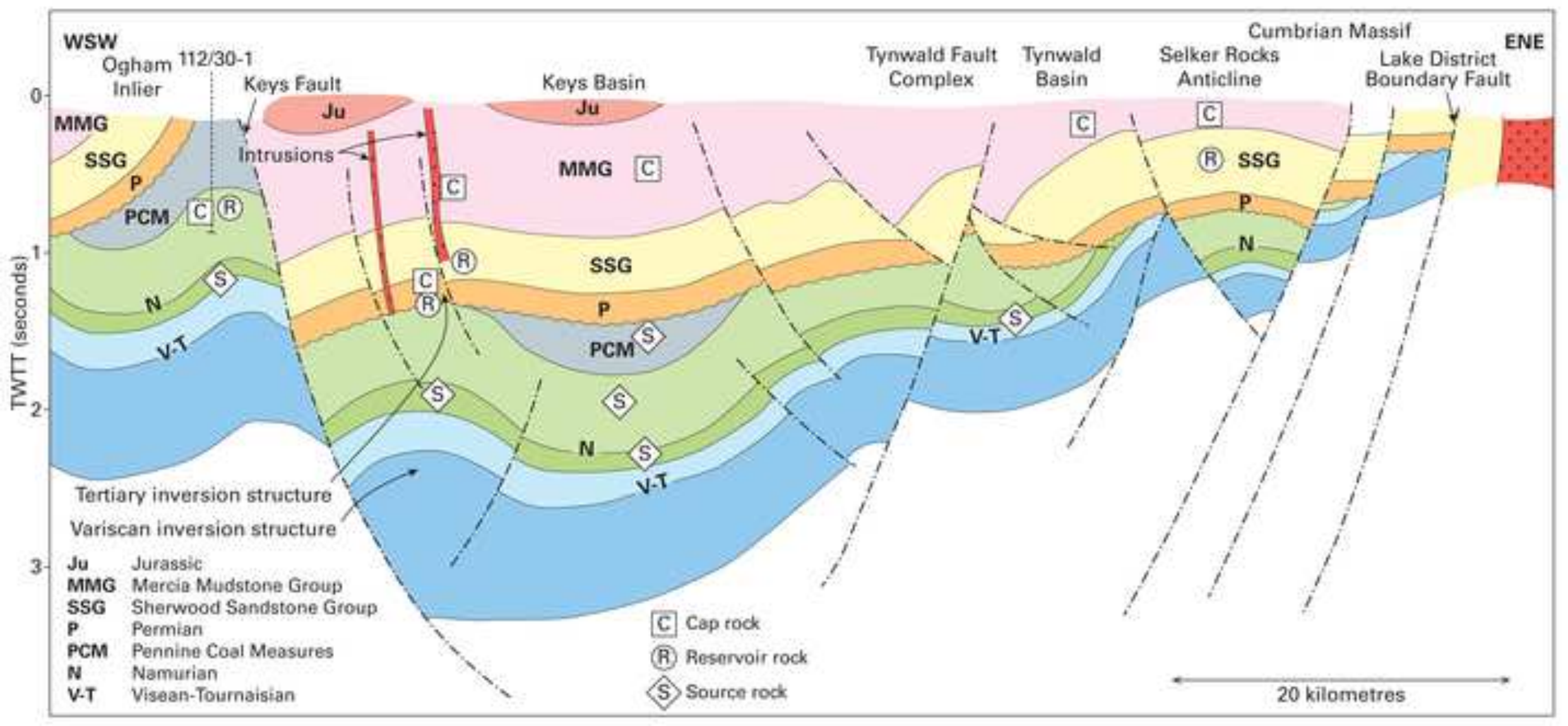




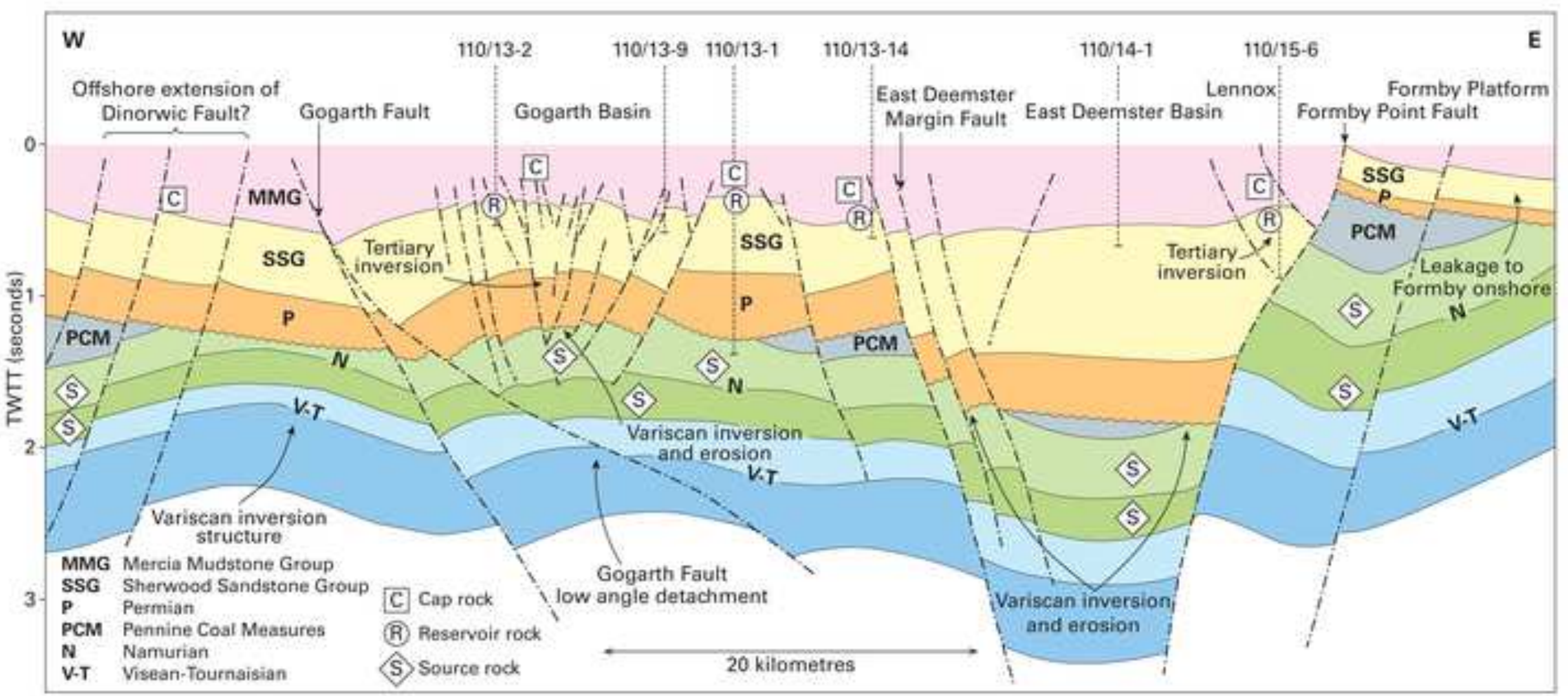

fshore extension of (1) (B)

(

S) Source rock 


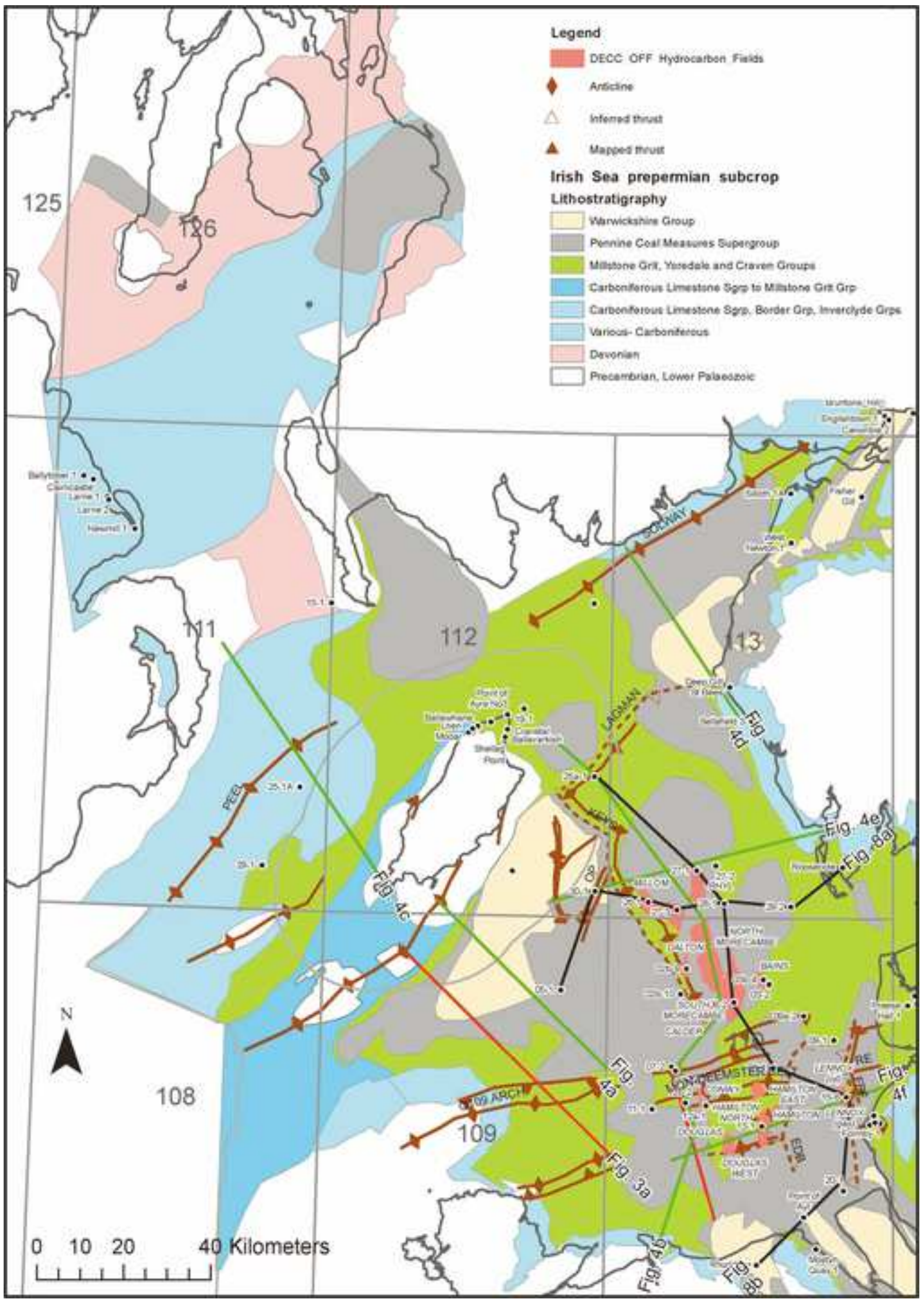




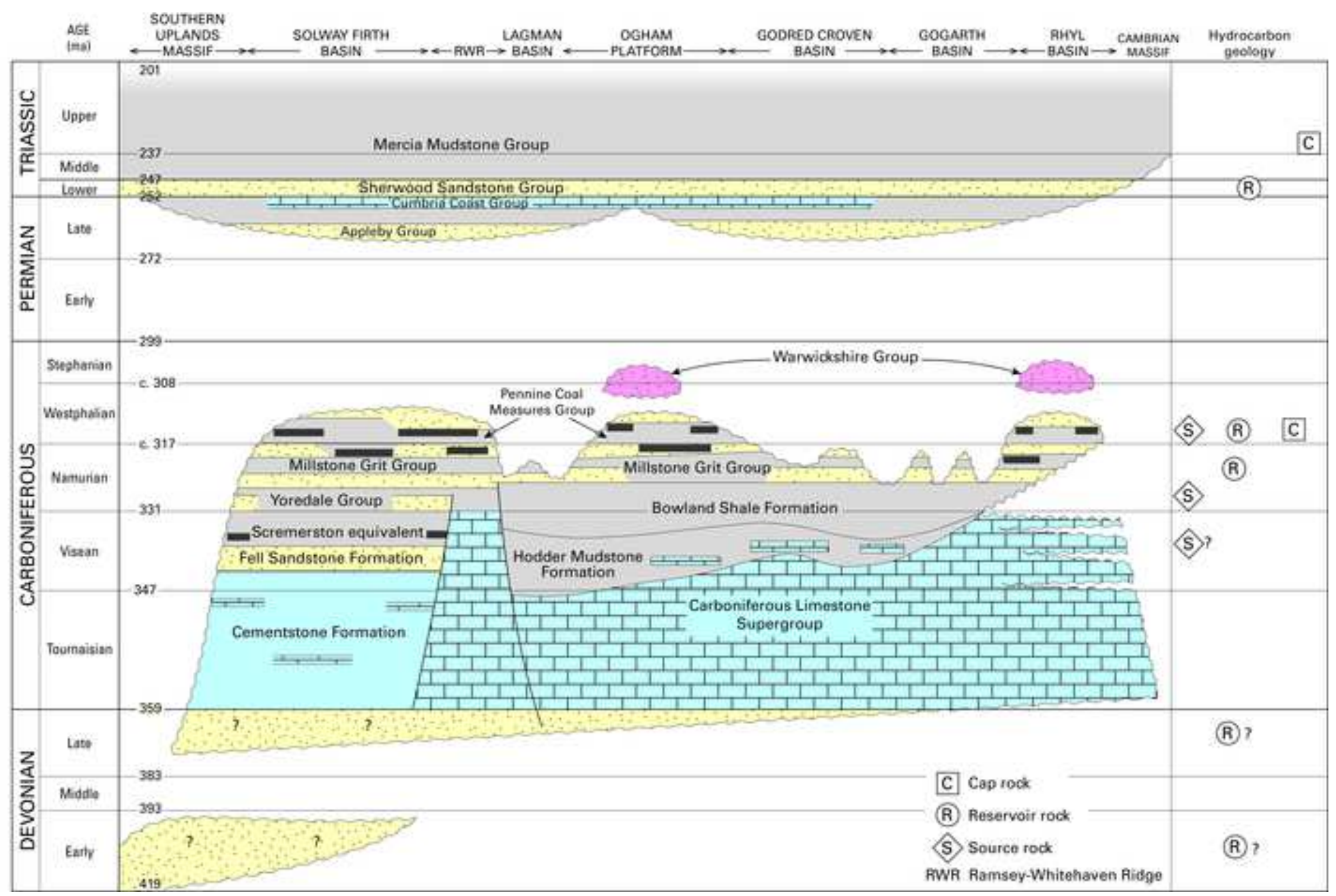




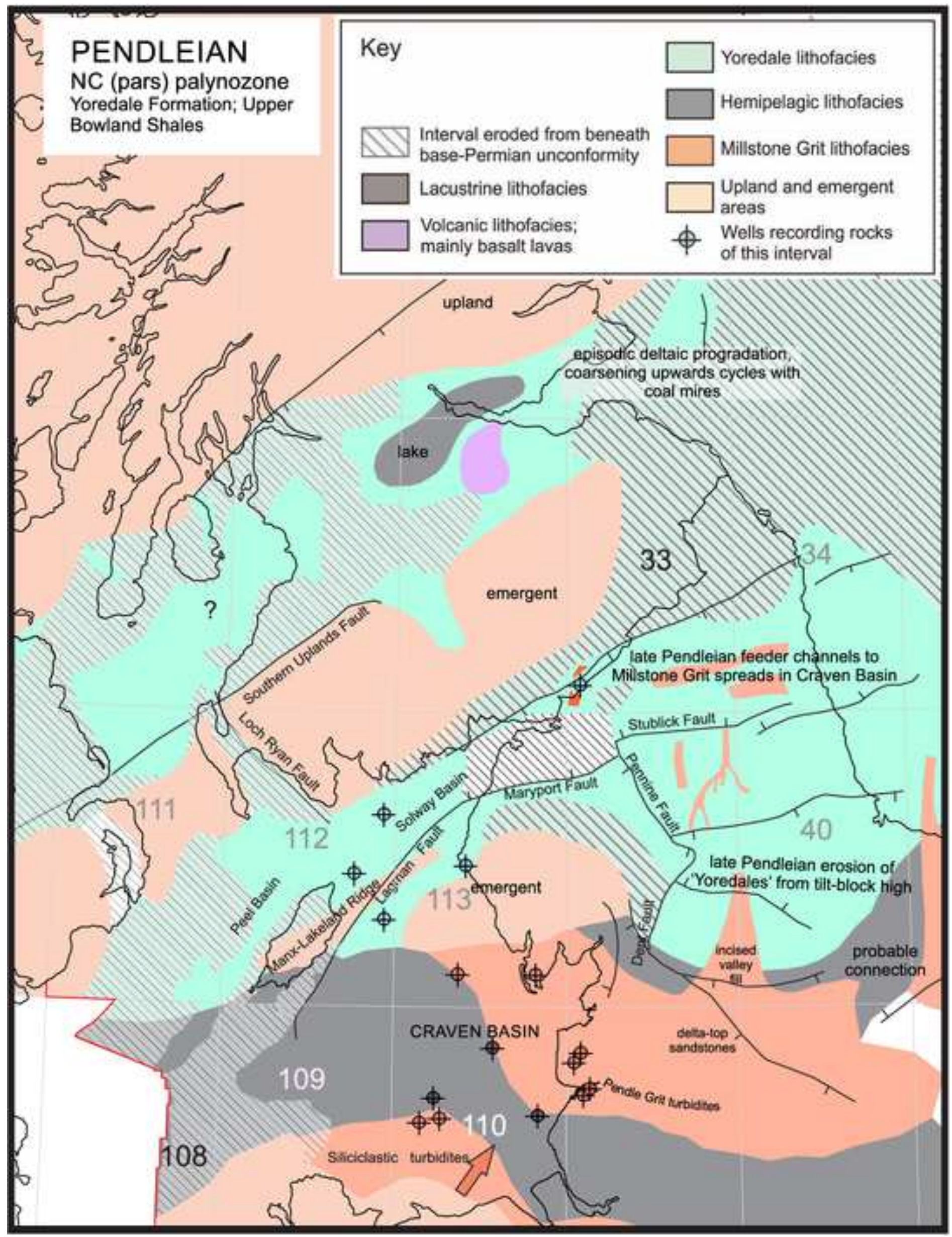




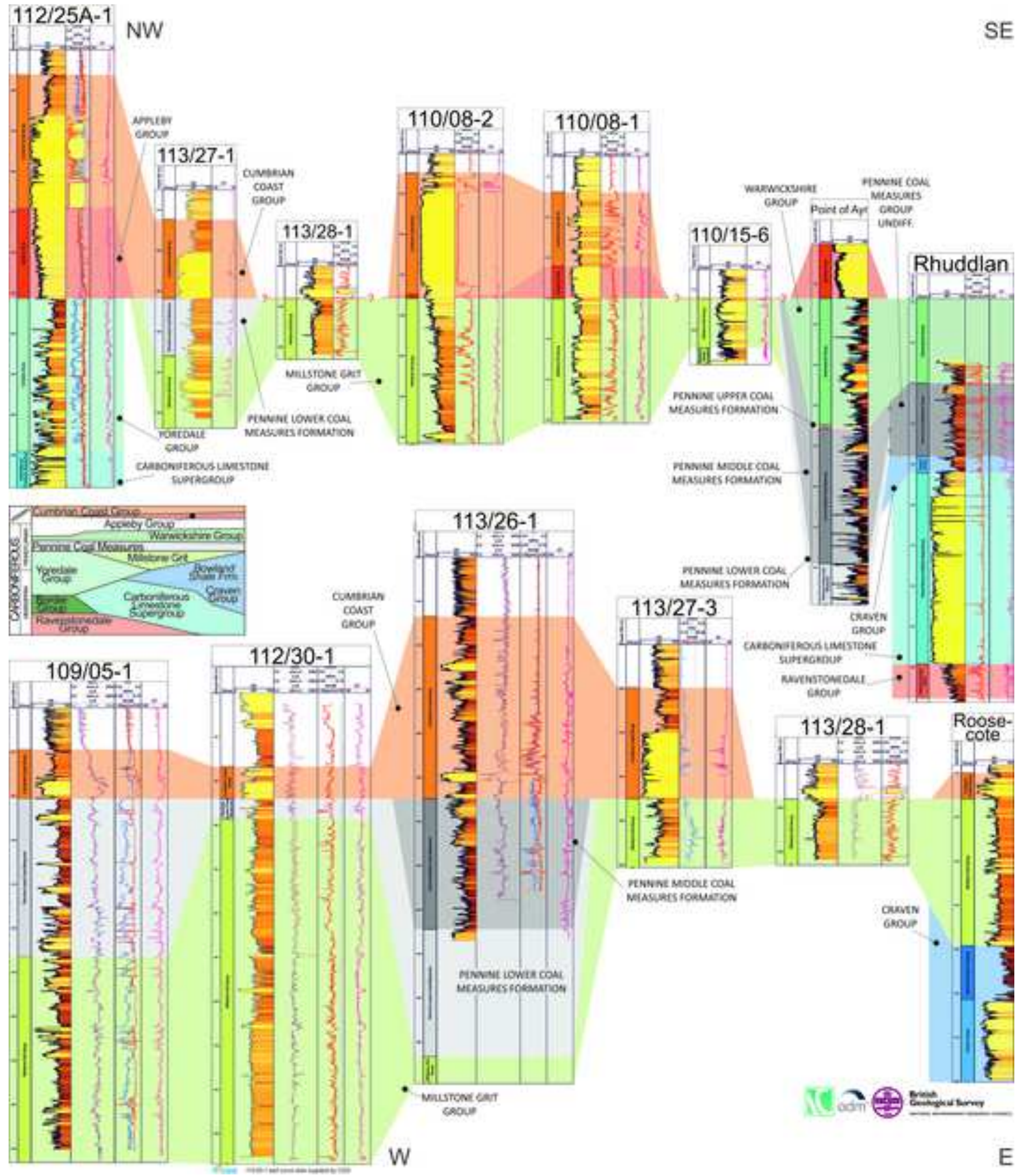




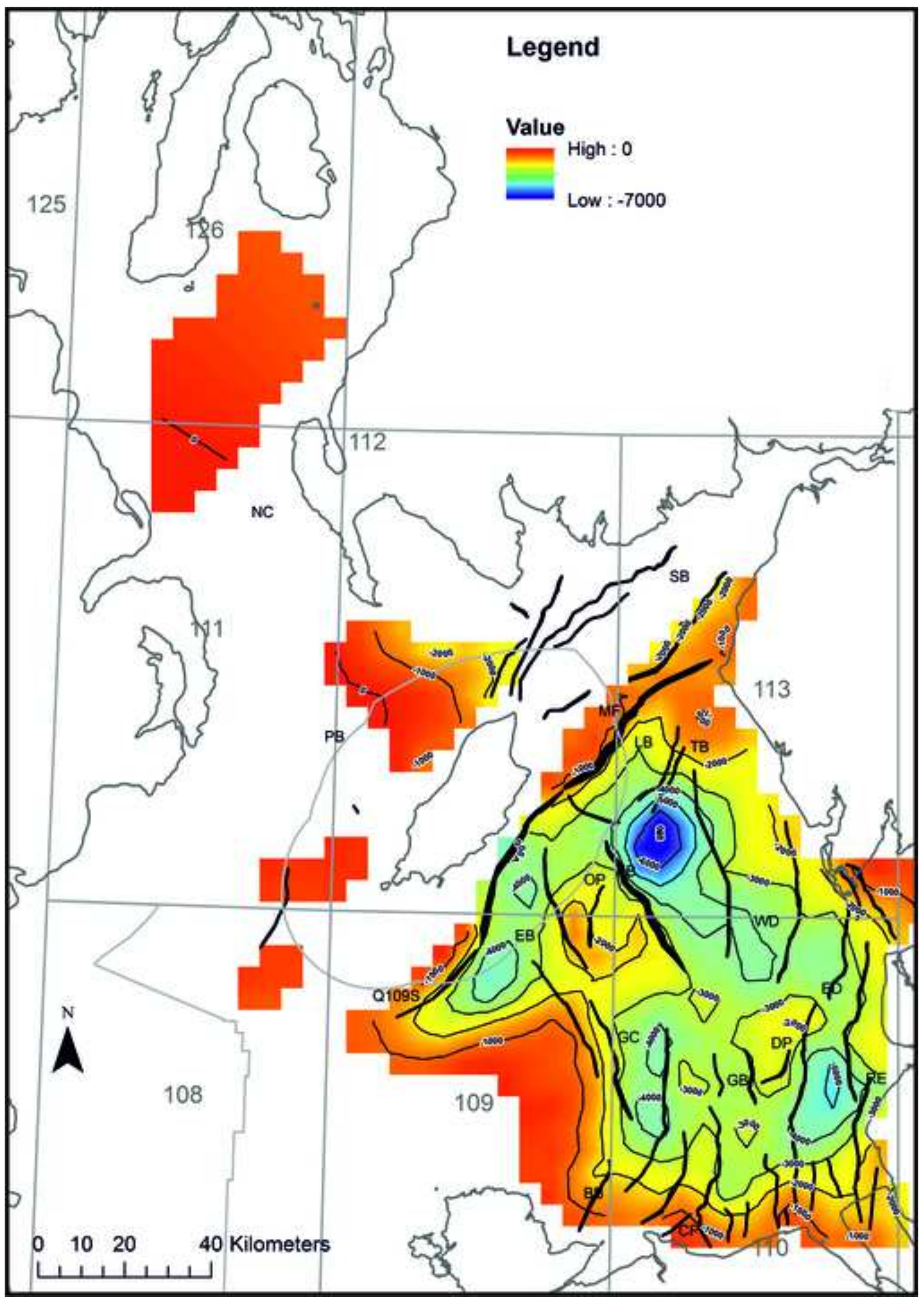


110/07b-6, S1 Hydrocarbons (mg/g)
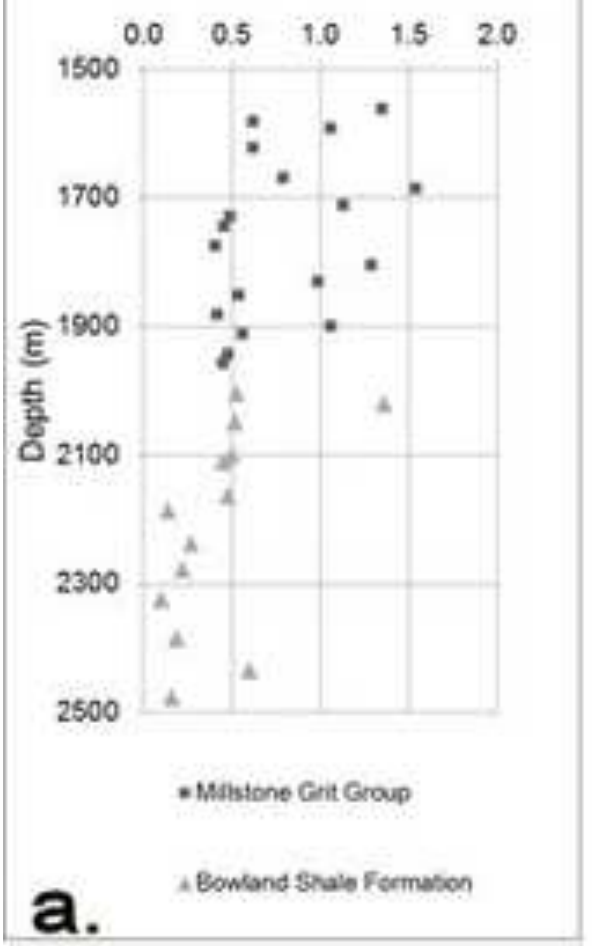

110/07b-6, VR (Ro measured)

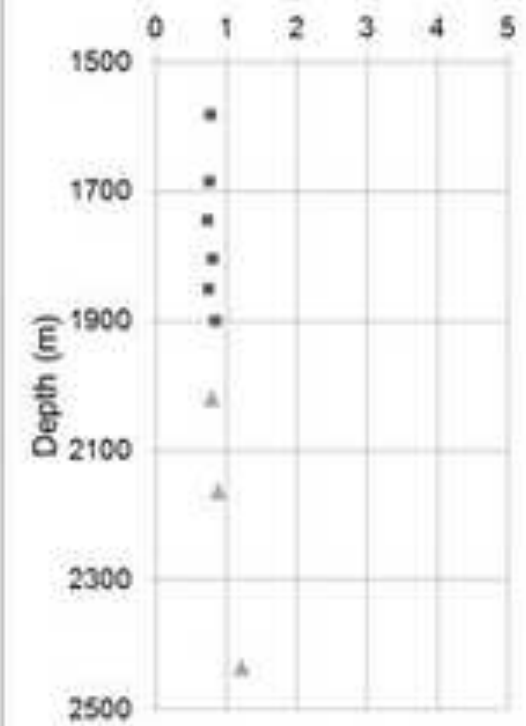

d. Elowatone Crit Grows
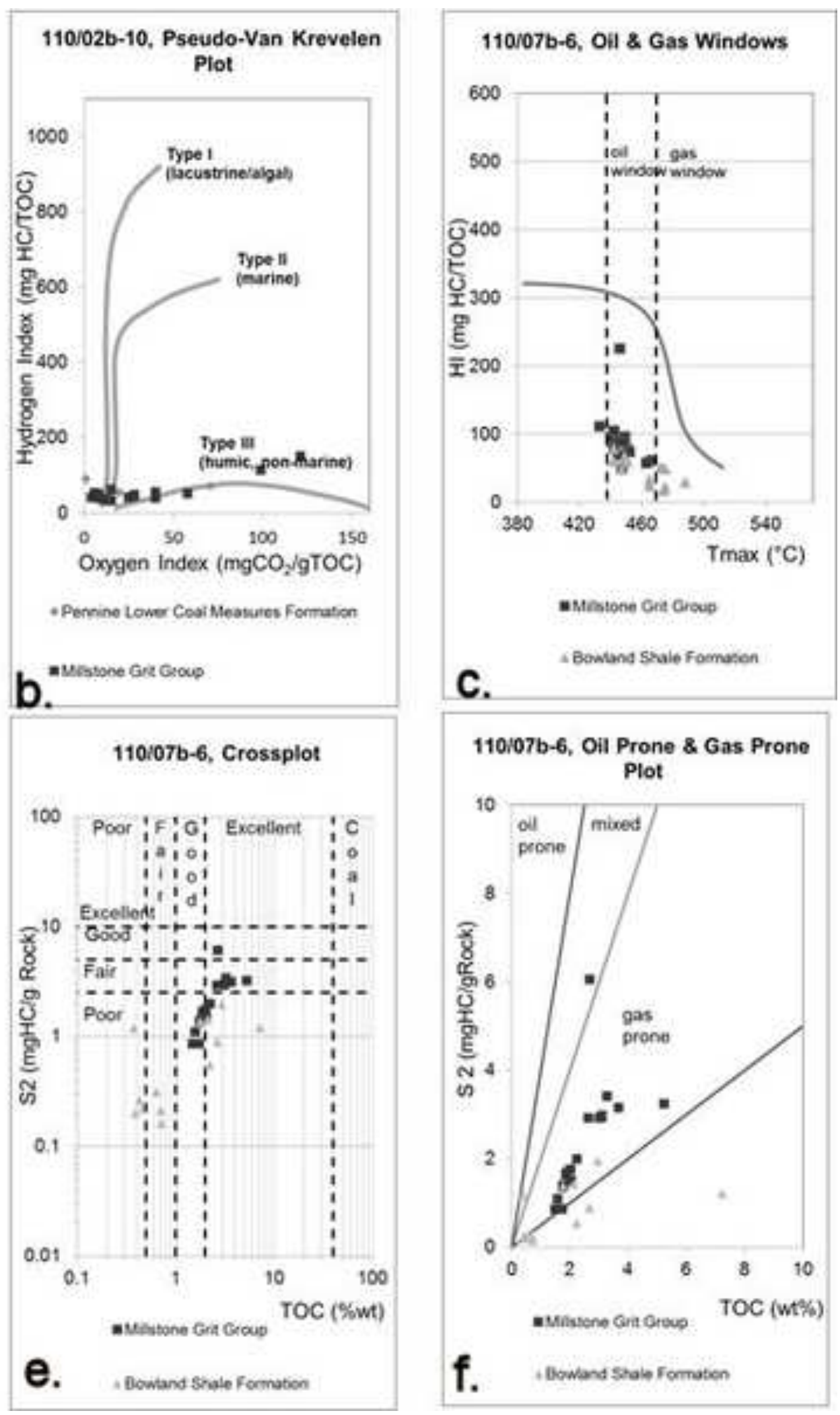

\section{0:07b-6, Oil Prone \& Gas Prone Plot}

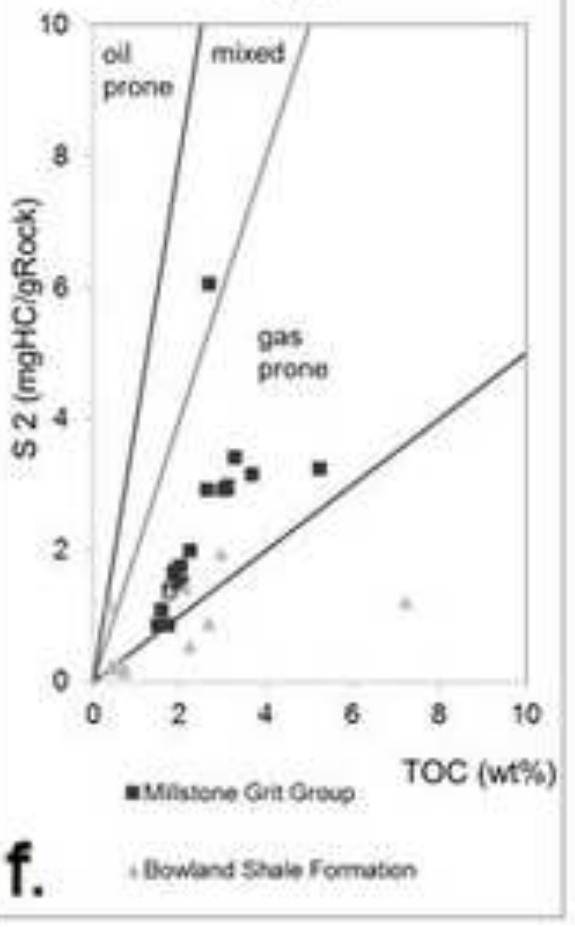




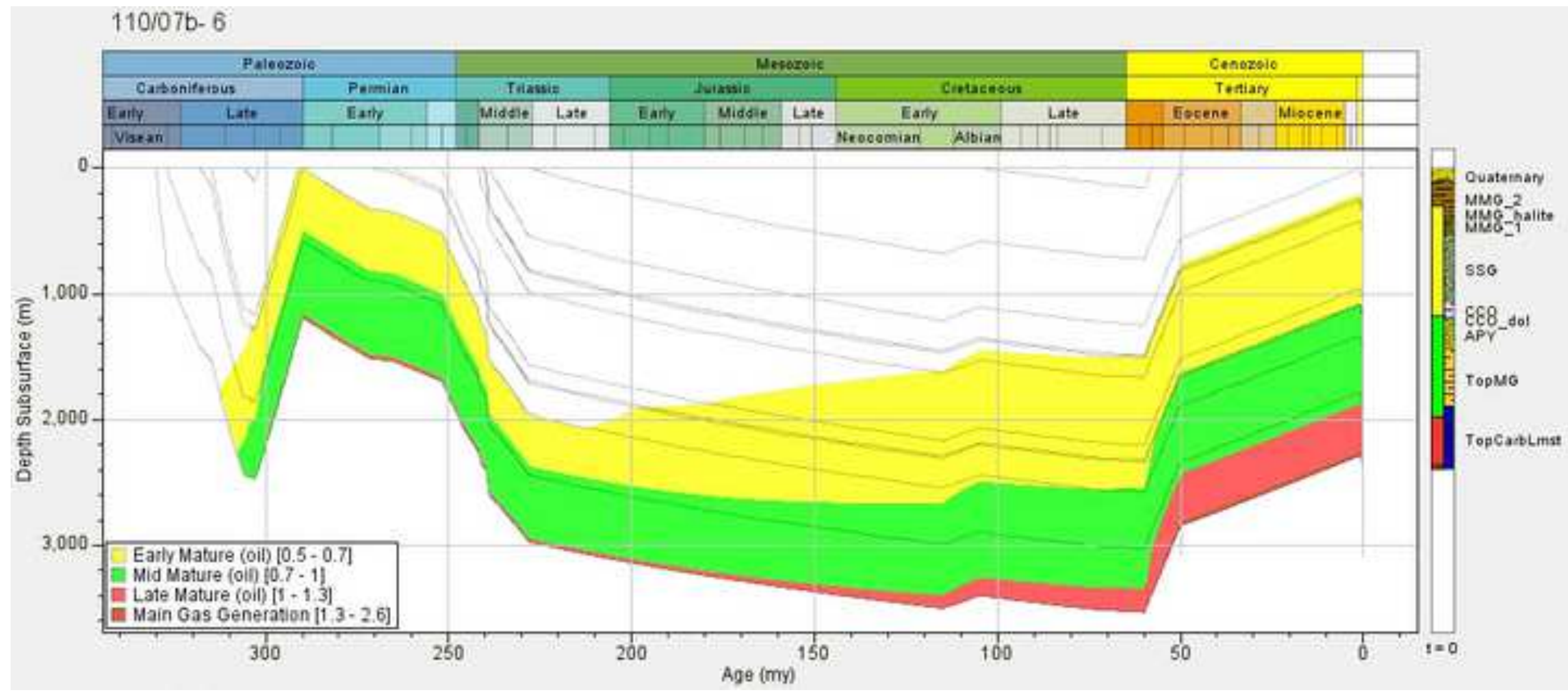




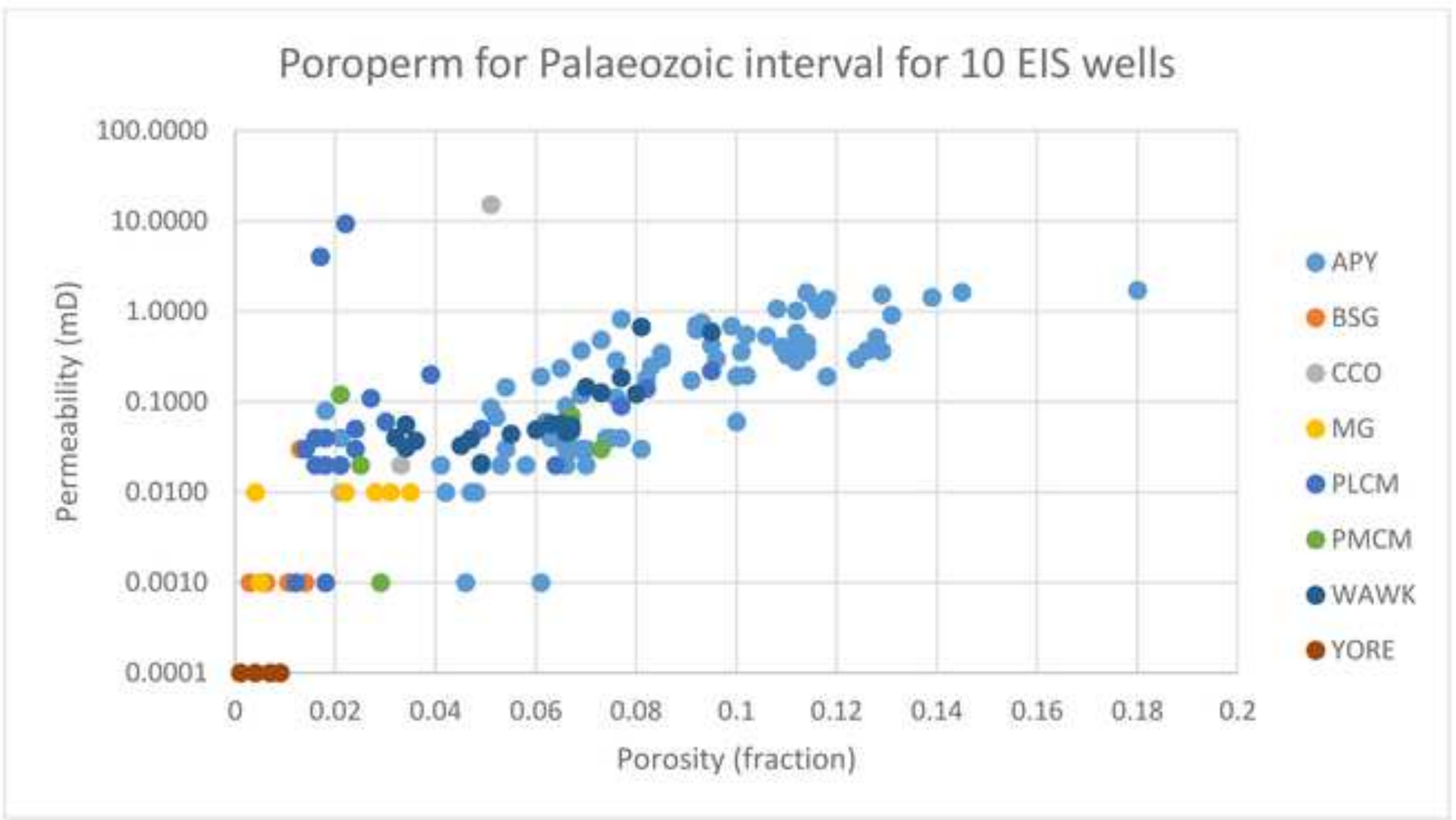

